
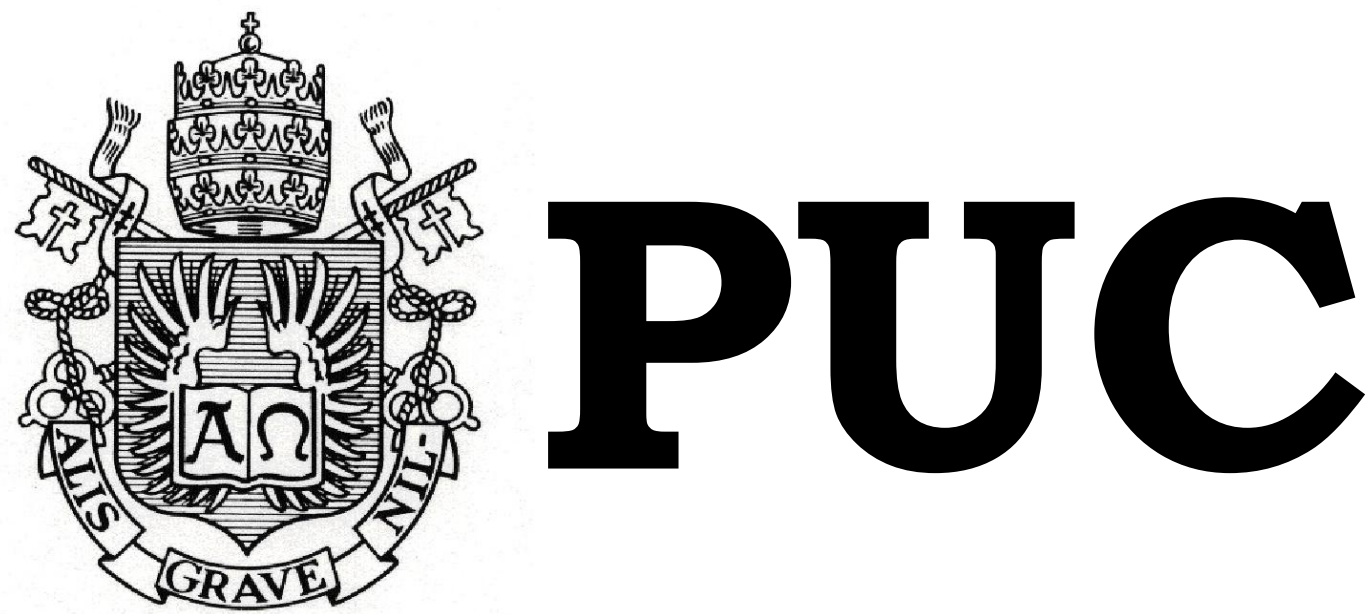

DEPARTAMENTO DE DIREITO

\title{
As Correntes Invisiveis da Indústria da Moda Brasileira
}

por

ANA CAROLINA DA ROCHA LEÃO MACHADO

ORIENTADOR: JOÃO BATISTA BERTHIER

LEITE SOARES

2017.2

PONTIFÍCIA UNIVERSIDADE CATÓLICA DO RIO DE JANEIRO

RUA MARQUÊS DE SÃO VICENTE, 225 - CEP 22453-900

RIO DE JANEIRO - BRASIL 



\title{
AS CORRENTES INVISÍVEIS DA INDÚSTRIA DA MODA BRASILEIRA
}

\author{
por
}

ANA CAROLINA DA ROCHA LEÃO MACHADO

Monografia apresentada ao Departamento de Direito da Pontificia Universidade Católica do Rio de Janeiro (PUC-Rio) como requisito parcial para a obtenção do Título de Bacharel em Direito.

Orientador: João Batista Berthier Leite Soares 
In memoriam de Helena Joas da Rocha Leão, Avó querida e para sempre amada. 


\section{AGRADECIMENTOS}

A Deus, força inteligente que se manifesta através do amor, sentimento que me move e me fortalece.

À minha avó, Helena, a quem dedico esse estudo monográfico, que sempre acreditou no meu potencial e hoje, lá das estrelas, olha por mim.

À minha mãe, Márcia, que me ensinou a ter garra na vida, enfrentar meus medos e ter fé acima de tudo.

À minha irmã, Laura, porque cada pequena conquista sua é uma grande vitória minha.

Ao Soneca, meu filho do coração, pela companhia de todas as horas e por sempre encher meu coração de amor.

Ao meu companheiro de alma e melhor amigo, Phillip, que caminha de mãos dadas comigo há três anos e sempre trouxe mais cor e luz à minha vida.

Aos meus grandes amigos do CEFET, Angelo, Beatriz, Caroline, Karline, Laís, Ricardo, Rodrigo e Thaís, pelo apoio nesses quase dez anos e por serem mais que uma família para mim.

À minha irmã da vida, Amanda, e ao meu afilhado Jack, que fazem meu coração atravessar fronteiras.

Aos meus queridos amigos da PUC, em especial à Carolina, Loane, Rebeca, Sol e Vitória, por me acompanharem durante esta aventura acadêmica e tornarem minha rotina mais leve e alegre com a sua amizade. 
Aos meus colegas e amigos de estágio, valendo-se ressaltar o Defensor Marcos Machado, a Procuradora Daniele Uryn e a Advogada Giulia Reis, que foram meus mestres do Direito prático.

Aos ilustres professores que fizeram parte da minha formação, com destaque para Aline Terra, Carlos Konder, Inês Alegria, João Berthier, Thiago Varela e Thula Pires, pelo exemplo a ser seguido de excelência acadêmica.

E, por fim, a todos que de alguma forma contribuíram para o meu desenvolvimento pessoal e profissional, muito obrigada. 


\section{RESUMO}

Este trabalho monográfico tem por objetivo desenvolver e expor a estreita relação entre o mercado fast fashion e a superexploração de trabalhadores imigrantes latino-americanos em oficinas clandestinas de costura localizadas nos centros urbanos brasileiros. Dessa forma, inicialmente, destaca-se a nova lógica de consumo que permite a produção a baixo custo mediante a sonegação de direitos do trabalhador em benefício do lucro, a estrutura de sweating system que a mantém e o consequente dumping social a ela associado. Além disso, cuida-se de esclarecer o que define o trabalho digno e como se revela os modos de execução da escravidão moderna, apresentando, em caráter complementar, parte específica sobre o tráfico de pessoas, tendo em vista a evidente ligação deste tipo penal com a conduta tema do presente estudo. Ainda, traz trato sobre a responsabilidade das grandes grifes que se aproveitam da superexploração deflagrada no interior de sua cadeia produtiva. Mais adiante, é exposto o caso paradigmático da multinacional ZARA, com a descrição dos resgates realizados em suas oficinas clandestinas e os desdobramentos de seus flagrantes. Também, são apresentados os mecanismos de enfrentamento do trabalho análogo ao escravo e, finalmente, é realizada análise da nova Portaria MTB 1.129/2017, que traz retrocessos significativos no que se refere à conceituação de trabalho escravo contemporâneo.

Palavras-Chave: Mercado Fast Fashion- Indústria da Moda Sweeting System - Dumping Social - Trabalho Decente - Escravidão Contemporânea - Trabalho Análogo ao Escravo - Superexploração Modos de Execução - Coação - Imigrantes - Hipervulnerabilidade Tráfico de Pessoas - Responsabilização em Cadeia - Subcontratações Intermediação de Mão de Obra - Grifes - Magazines - Fornecedores Oficinas Clandestinas - ZARA - Flagrantes - Mecanismos de Combate. 


\section{SUMÁRIO}

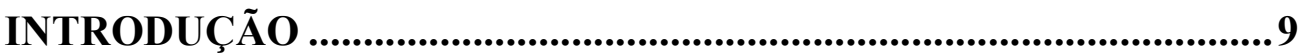

PARTE I - PANORAMA GERAL SOBRE A INDÚSTRIA DA MODA

1.REFLEXÕES SOBRE O FAST FASHION COMO NOVO SISTEMA DE CONSUMO

2.O FAST FASHION E A LÓGICA DO SWEATING SYSTEM.

13

3.AS NOVAS PRÁTICAS CONCORRENCIAIS DA INDÚSTRIA DA MODA - O

DUMPING SOCIAL.

18

PARTE II - UMA BREVE ANÁLISE SOBRE O TRABALHO DECENTE E AS CONCEITUAÇÕES QUE ENVOLVEM O



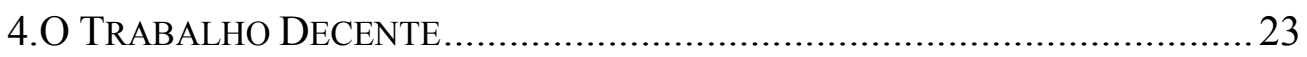

5.O TRABAlHo ANÁlogo ao ESCRAVO - DeFinição, Conceitos E Modos

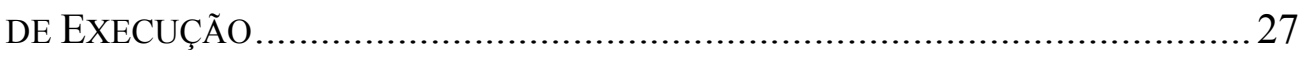

5.1 O TRABALHO ESCRAVO TÍPICO E O CONTEMPORÂNEO …......................28

5.2 O ART. 149 DO Código Penal E A AMPliaÇão dos MOdOS DE

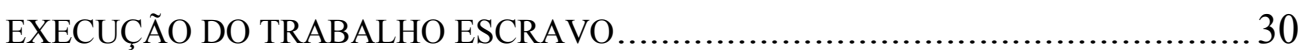

5.3 A SUJEIÇÃo DE IMIGRANTES AO TRABALHO ANÁLOGO AO ESCRAVO NO INTERIOR DA CADEIA PRODUTIVA DA INDÚSTRIA DA MODA BRASILEIRA.. 38 PARTE III - O TRÁFICO DE IMIGRANTES LATINOAMERICANOS PARA A SUSTENTAÇÃO DO SETOR TÊXTIL.......43 PARTE IV - A CONFIGURAÇÃO DA RESPONSABILIDADE DAS MAGAZINES ANTE O TRABALHO ESCRAVO IDENTIFICADO NA

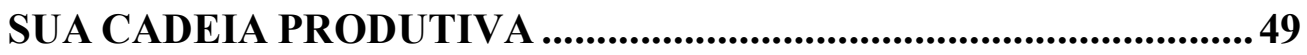

6.A TEORIA DA SUBORDINAÇÃo ESTRUTURAL ........................................... 49

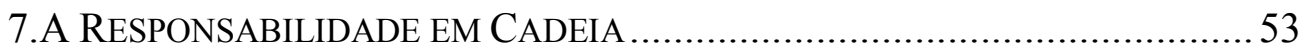

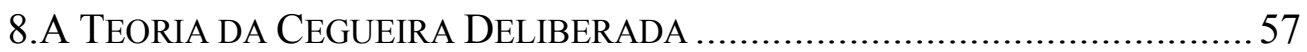

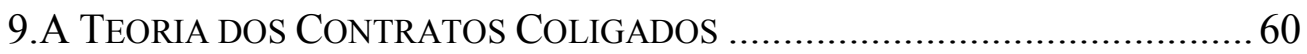

10.A Responsabilidade Ambiental no Contexto do Ambiente DE

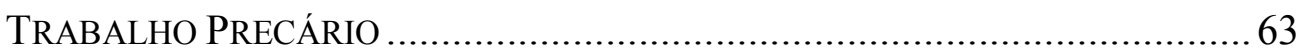

PARTE V - CASO PARADIGMÁTICO: ZARA ...................................68

PARTE VI - A LUTA PELA ERRADICAÇÃO DO TRABALHO ESCRAVO CONTEMPORÂNEO ........................................................82

11.APRESENTAÇÃO DOS MECANISMOS DE COMBATE ………......................82

11.1 AÇÕES COORDENADAS PREVENTIVAS E REPRESSIVAS .........................85

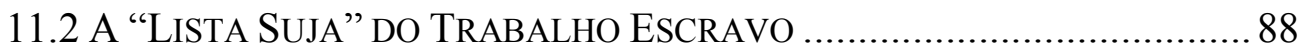


11.3 A LeI ESTADUAL No 14.946/2013 - São PAULO …………………........91

PARTE VII: A SOMBRA DO RETROCESSO - PORTARIA MTB

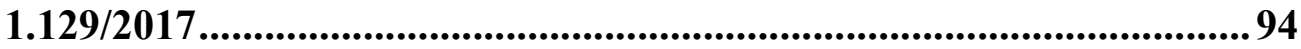

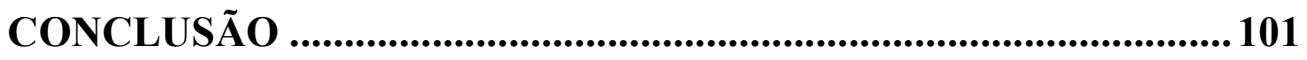

REFERÊNCIAS BIBLIOGRÁFICAS................................................. 104 


\section{LISTA DE ABREVIAÇÕES}

CC - Código Civil

CDC - Código de Defesa do Consumidor

CLT - Consolidação das Leis do Trabalho

$\mathrm{CP}$ - Código Penal

CRFB - Constituição da República Federativa Brasileira

GEFM - Grupo Especial de Fiscalização Móvel

MPF - Ministério Público Federal

MPT - Ministério Público do Trabalho

MT - Ministério do Trabalho (antigo MTE - Ministério do Trabalho e

Emprego)

NR - Norma Regulamentadora

OIT - Organização Internacional do Trabalho

OJ - Orientação Jurisprudencial

STF - Supremo Tribunal Federal

TAC - Termo de Ajustamento de Conduta

TST - Tribunal Superior do Trabalho 


\section{INTRODUÇÃO}

No dia 24.04.2013, mais de mil pessoas que trabalhavam em condições de superexploração no complexo de oficinas têxteis do edifício Rana Plaza, em Bangladesh, faleceram e 2,5 mil ficaram feridas devido ao desmoronamento do prédio. ${ }^{1}$

Um dia antes do acidente, engenheiros vistoriaram o edifício e condenaram a sua estrutura, recomendando o fechamento das oficinas que ali funcionavam, o que foi sumariamente ignorado por muitos dos empregadores que, apesar do parecer técnico, ameaçaram demitir os trabalhadores que faltassem ao trabalho por medo das enormes rachaduras nos pilares de concreto que sustentavam a construção. ${ }^{2}$

Tal acontecimento ficou conhecido como uma das maiores tragédias industriais da história e se tornou símbolo das reiteradas violações aos direitos trabalhistas que vem sendo mundialmente deflagradas no interior das cadeias produtivas das grandes magazines.

As causas que deram origem ao episódio relatado não se diferem daquelas que vivemos aqui no Brasil, pelo contrário, podemos visualizar as cicatrizes deixadas pelos interesses do capital desregulado que visa somente ao lucro em detrimento da dignidade humana.

A corrida desenfreada da indústria têxtil pela produção de peças de vestuário acessíveis a baixo custo se transformou em um fenômeno global, que busca terceirizar ou até mesmo quarteirizar sua manufatura para aqueles que são excluídos socialmente através de subcontratações

\footnotetext{
${ }^{1}$ HASHIZUME, Maurício. Tragédia em Bangladesh simboliza despotismo do lucro. In: Repórter Brasil. 10/05/2013. Disponível em: <http://reporterbrasil.org.br/2013/05/tragedia-em-bangladeshsimboliza-despotismo-do-lucro/>. Acesso em 11 Out. 2017.

2 RIVAS, Katherine. Cicatrizes da tragédia em oficinas têxteis de Bangladesh. In: Carta Capital. 23/05/2013. Disponível em: <http://envolverde.cartacapital.com.br/cicatrizes-da-tragedia-emoficinas-texteis-de-bangladesh/>. Acesso em 11 Out. 2017.
} 
sucessivas, aproveitando-se da exploração da miséria e da falta de instrução que, clandestinamente, coisifica e mata o ser trabalhador.

Nesse sentido, o presente estudo visa esclarecer como a mencionada lógica de consumo e produção, em especial, o chamado mercado fast fashion, vem alimentando o ciclo de superexploração do costureiro imigrante latino-americano em âmbito nacional.

Para tanto, a primeira parte deste trabalho expõe a nova tendência de mercado seguida pelas grandes marcas, o modelo fast fashion, que permite a redução de custos pela adoção da lógica sweating system, através da fragmentação precária do processo produtivo, facilitando a ocorrência do trabalho análogo ao escravo e, consequentemente, contribuindo para o fomento de práticas de concorrência desleal, a exemplo do dumping social.

A segunda parte passa a apresentar os direitos mínimos necessários para que se configure o trabalho decente, a fim de que seja estabelecido um contraponto ideal ao trabalho análogo ao escravo.

Em seguida, diferenciamos a escravidão do Brasil colônia da escravidão contemporânea, sendo certo que não mais estamos diante de uma superexploração legalizada que ratifica a propriedade de um ser humano sobre o outro.

Ao final, são definidos e, posteriormente, explicitados através de casos reais, os modos de execução da escravidão contemporânea, sejam aqueles convencionais, como o trabalho forçado, o trabalho em condições degradantes, as jornadas exaustivas e a escravidão por dívida, sejam os que são assim conhecidos por equiparação, como aquele que nega ao trabalhador acesso aos meios de transporte, que mantém vigilância ostensiva no local de trabalho e que retém documentos e objetos pessoais do trabalhador, todos com o intuito de mantê-lo em condição de superexploração. 
A terceira parte tem por objetivo elucidar o tipo penal de tráfico de pessoas, tendo em vista sua relação direta com o crime objeto de estudo, sendo meio recorrente para a entrada no país dos trabalhadores mais explorados pelas oficinas clandestinas, os imigrantes ilegais latinoamericanos.

A quarta parte discorre sobre a responsabilização das magazines perante a identificação de prática de trabalho análogo ao escravo no interior de suas cadeias produtivas, o que é, inicialmente, entendido como uma responsabilidade direta, pelo reconhecimento do vínculo de trabalho dentro da teoria da subordinação estrutural e, eventualmente, definido como responsabilidade solidária, com base nas teorias da responsabilização em cadeia, da cegueira deliberada, dos contratos conexos e do meio ambiente de trabalho precário.

Dadas as devidas conceituações ao longo do estudo ora desenvolvido, a quinta parte apresenta o caso paradigmático da grande grife ZARA, reconhecida mundialmente, que foi protagonista dos primeiros grandes flagrantes de trabalho análogo ao escravo na indústria têxtil brasileira.

A sexta parte cuida dos principais mecanismos de combate ao trabalho escravo moderno, com destaque para as ações integradas de prevenção e repressão mobilizadas por uma rede necessária de apoio contínuo (Sociedade Civil - ONGs - Sindicatos - Polícia Rodoviária GEFM - MPT - Autoridades do Poder Judiciário - etc.), para a "lista suja" e para Lei Estadual n ${ }^{\circ} 14.946 / 2013$ (SP).

A sétima e última parte, por fim, trata da nova Portaria MTB 1.129/2017, publicada em 16.10.2017, que traz sérios retrocessos ao país em matéria de direitos humanos, como o condicionamento das condições degradantes e das jornadas exaustivas à presença obrigatória de cárcere privado involuntário, desconsiderando as particularidades da escravidão 
contemporânea como clara estratégia política em favor da bancada ruralista do Congresso Nacional. 


\section{PARTE I - PANORAMA GERAL SOBRE A INDÚSTRIA DA MODA}

\section{Reflexões sobre o Fast Fashion como Novo Sistema de Consumo}

Conforme dados atualizados de 2016, o Brasil se encontra na posição de quinto maior produtor têxtil do mundo, com o faturamento da cadeia de confecções no valor de US\$ 37 bilhões, empregando no setor 1.5 milhão de trabalhadores diretos e 8 milhões de trabalhadores indiretos. ${ }^{3}$

Tais impressionantes números somente foram possíveis com o advento da Terceira Revolução Técnico Científica, quando, a partir da década de 1980, consolidou-se um novo modelo de produção denominado Fast Fashion, que se sustenta pela intensificação do processo de globalização econômica e o estabelecimento mundial de uma sociedade de consumo.

O Fast Fashion (Moda Rápida) é um modelo derivado do sistema atual de produção capitalista denominado Toyotismo, que igualmente busca flexibilizar a produção a partir do rápido escoamento e distribuição de mercadorias por meio da automoção e da lógica just-in-time. ${ }^{4}$

Trata-se de novo conceito de roupa incorporado pelas grandes varejistas do setor têxtil, a exemplo da H\&M, Zara, Renner, C\&A, Heringer, Marisa e Forever 21, cujo objetivo é a produção de moda rápida e em grande triagem a preço acessível para camadas mais populares.

O ônus do preço acessível, entretanto, não desaparece, pelo contrário, este é repassado aos trabalhadores das plantações de algodão e das oficinas de costura terceirizadas (custo social) e para o meio ambiente

\footnotetext{
${ }^{3}$ ABIT TÊXTIL E CONFECÇÃO. Perfil do Setor. Disponível em: $<$ http://www.abit.org.br/cont/perfil-do-setor>. Acesso em 15 ago. 2017.

${ }^{4}$ APOLINÁRIO, V. Análise do Toyotismo e dos seus Princípios Racionalizantes aplicados à gestão da produção e do trabalho. Interface - Revista do Centro de Ciencias Sociais Aplicadas, v. 13, n. 2, p. 5-19, 2016.
} 
(custo ambiental). ${ }^{5}$

Sob a égide deste novo sistema de consumo, as corporações de sucesso passaram a produzir principalmente marcas, e não mais produtos, posto que a flexibilidade do novo modelo econômico possibilita a terceirização/quarteirização de toda a sua manufatura. A marca traduz um conceito, um estilo de vida, e a produção de significado dos objetos tornouse a atividade principal das grandes grifes.

A nova abordagem de atribuição de sentido às roupas com o foco no marketing e não na produção e consumo conscientes acabou por naturalizar a percepção do "outro" como mercadoria, equiparando as relações humanas a bens de simples aquisição e descarte, bens consumíveis. Nesse mesmo rumo, seguiram-se as relações laborais, em que os trabalhadores são vistos como mercadorias que podem ser descartadas, importando-se o consumidor somente com o que lhe traz satisfação imediata dentro da estrutura individualista construída pela cultura do consumo, ou seja, importando-se somente com o produto final.

Registra-se que essa visão trazida pela sociedade de consumo e sua consolidação com o padrão Fast Fashion desconsidera a humanidade do trabalhador e o transforma em coisa, sendo o obreiro apenas mais um insumo a ser consumido no processo produtivo, o que permite a sonegação de direitos trabalhistas em prol do baixo custo de produção e da maximização dos lucros a qualquer preço. ${ }^{6}$

Importante salientar, ainda, que não somente a flexibilidade e a automação derivadas da Terceira Revolução Industrial deram margem para o modelo apresentado, como também, o seu consequente desemprego

\footnotetext{
5 OMS, Carolina; QUEIROZ, Nana. Moda a qualquer custo. In: Revista AZMina. 28/08/2015 9/03/1988. Disponível em <http://azmina.com.br/2015/08/moda-a-qualquer-custo/>. Acesso em 02 jul. 2017.

${ }^{6}$ TIMÓTEO, Gabrielle Loiuse Soares. Trabalho em condições análogas à escravidão na sociedade de consumo. In: PRADO, Adonia Antunes; GALVÃO, Edna Maria; FIGUEIRA, Ricardo Rezende (Orgs). A Universidade Discute a Escravidão Contemporânea: Práticas e Reflexões. $1^{\mathrm{a}}$ ed. Rio de Janeiro: Mauad X, 2015. p. 239-251.
} 
estrutural.

O mercado Fast Fashion também se consolidou através da massa de desempregados que, por conta das novas tecnologias, não fora absorvida pelo mercado de trabalho e passava a se submeter a serviços indignos que minimamente pudessem auxiliar no sustento do indivíduo e de sua família, permitindo a exploração extrema do trabalhador por meio da coerção coletiva do capital subsidiada pelo "exército industrial de reserva" disponível no mercado de trabalho desregulado.

Tais trabalhadores, apesar de serem tidos como mão de obra barata e descartável para o empresariado têxtil diante das condições de hipervulnerabilidade em que se encontram, representam o sustentáculo da produção varejista em larga escala.

Encontrados comumente na ponta das cadeias produtivas, tornam-se mais suscetíveis à retroalimentação do ciclo de trabalho escravo contemporâneo que envolve a Indústria da Moda, o que torna impositiva a reestruturação do mercado atual e a fiscalização em cadeia a partir da matriz para que se estabeleça como padrão o trabalho humanizado dentro do setor têxtil. 


\section{O Fast Fashion e a lógica do Sweating System}

A indústria da moda se segmenta pelas práticas que adota dentro de sua cadeia produtiva. Existem empresas que buscam a vivência de uma economia sustentável e empregam sistemas de produção que resguardam seus trabalhadores e reafirmam a responsabilidade socioambiental de sua marca, a exemplo daquelas que se comprometem com o modelo Factory System (Sistema de Fábrica), e outras corporações, coincidentemente as envolvidas no mercado fast fashion, que têm optado pela aplicação de práticas concorrencialmente condenadas, como o dumping social, e que se mostram totalmente alheias ao princípio da dignidade humana aceitando o trabalho análogo ao escravo na teia de sua produção, características próprias daquelas que aderem à lógica de negócios aplicada no Sweating System (Sistema de Suor).

O Factory System se define por privilegiar a contratação direta de trabalhadores, de modo a cumprir-se regularmente com o estipulado no contrato do trabalho, estando presente a concentração da fabricação de roupas em uma mesma unidade produtiva, não havendo a transformação simbiótica do local de trabalho em moradia.

Tal sistema, contudo, se apresenta completamente avesso ao padrão de superexploração delineado pelo Sweating System, caracterizado pela busca desenfreada do menor custo de produção através da precarização do trabalho, subcontratando-se trabalhadores com o pagamento de salários indecentes - inferiores ao necessário para se viver dignamente - para o exercício da confecção e costura, com impacto no preço das peças produzidas, vendidas a baixo custo.

Mais propriamente, o Sweating System manifesta como peculiaridade a simbiose entre casa-trabalho, não havendo uma separação saudável entre o que é definitivamente local de trabalho e o que se constitui 
como domicílio do trabalhador, de modo a se criar a figura híbrida do Sweatshop (Loja de Suor), que busca ocultar a exploração do trabalhador por meio da caracterização destes locais de trabalho e moradia como fábricas domésticas, dificultando a atuação do poder estatal em impor e fiscalizar o cumprimento das normas trabalhistas, vez que o mencionado controle é mais fácil de ser realizado a nível empresarial do que residencial.

Além disso, outra marca notável é a "fragmentação seletiva do processo fabril", tendo em vista que as atividades que necessitam de maior nível de instrução se mantém internalizadas pela empresa, enquanto que aquelas que carecem de mão de obra braçal e de baixa qualificação tendem a ser terceirizadas, ou até quarteirizadas, para fornecedores externos. ${ }^{7}$

Sobre o referido sistema, Renato Bignami faz as seguintes considerações:

(...) a produção está toda fracionada em uma cadeia de pequenas e microempresas que concorrem entre si mesmas, derrubando o valor do trabalho e ocasionando as péssimas condições no ambiente laboral. Cada célula de produção é responsável pela manufatura de uma parte da peca. A subcontratacão advinda dessa relação é estabelecida em virtude do menor preço e a contratação se faz na base da peça produzida e por prazo de entrega. Essa lógica vai descendo nas camadas sociais, segundo o nível de terceirização, até chegar ao obreiro, que também absorve, completamente, o sistema de produção, trabalhando e ganhando por peça e competindo com seus pares por mais trabalho e, consequentemente, mais dinheiro. ${ }^{8}$ (grifo nosso)

Nesse liame, é possível verificar que o Sweating System não somente se mostra precário na sua própria organização, como também exibe essa precariedade tanto nas relações de trabalho que contempla, como nas relações de mercado entre as empresas que compõem o setor, o que progride na caracterização do que hoje conhecemos como dumping social.

\footnotetext{
${ }^{7}$ BRASIL. Ministério Público do Trabalho. Procuradoria Regional do Trabalho da $2^{\mathrm{a}}$ Região. Ação Civil Pública. Réu: M5 Indústria e Comércio Ltda. 2014. Disponível em: $<$ http://reporterbrasil.org.br/documentos/acp-mofficer.pdf>. Acesso em 14 jul. 2017

${ }^{8}$ BIGNAMI, Renato. Trabalho escravo contemporâneo: O sweating system no contexto brasileiro como expressão do trabalho forçado urbano. Disponível em: $<$ https://www.sinait.org.br/arquivos/artigos/artigo19216c4627d24e2563a4335ceb2c9469.pdf>. Acesso em 02 ago 2017. p. 7.
} 


\section{As novas práticas concorrenciais da Indústria da Moda}

\section{- O Dumping Social}

Nossa ordem econômica está fundada no valor social do trabalho e na livre iniciativa, ambos preceitos consagrados pelo art. $1^{\circ}$ da Carta Magna brasileira, razão pela qual se busca resguardar os princípios vinculados à lealdade concorrencial a partir da repressão de práticas antimercadológicas, a exemplo do Dumping Social.

O Dumping Social ocorre através da redução dos custos da produção a partir da sonegação de direitos trabalhistas, ou seja, o produto passa a ser vendido por um preço mais barato à custa da superexploração desenfreada do trabalhador.

Dessa forma, a mencionada prática não somente prejudica os trabalhadores sujeitos a esta realidade, como também os empregadores que buscam gerenciar seu negócio de maneira regular, vez que a concorrência desleal acaba os excluindo do mercado ou, até mesmo, incentivando-os a igualmente adotar procedimentos que consolidam o trabalho análogo ao escravo.

Sobre a instigação do empreendedor regular à prática de mecanismos que incidem na concorrência desleal, ensina-se que:

Tal prática acaba, pois, favorecendo àquelas empresas que não observam a legislação trabalhista em detrimento daquelas que cumprem as regras impostas pelo ordenamento trabalhista. Dessa forma, a empresa inadimplente com as obrigações laborais acaba se favorecendo, pois gasta menos com o pagamento das obrigacões legalmente impostas, o que as possibilita baratear seus produtos, gerando assim uma concorrência desleal em face das outras empresas. Essa conduta acaba estimulando a burla ao cumprimento efetivo das normas trabalhistas, gerando um círculo vicioso de desrespeito aos direitos sociais, constitucionalmente garantidos. ${ }^{9}$ (grifos nossos)

Quanto à sua construção jurisprudencial, o Dumping Social vem se

\footnotetext{
${ }^{9}$ CHAVES, Maria Cláudia Gomes. Dumping social como fator de precarização das relações de trabalho. In: Conteudo Juridico, Brasilia-DF: 16/04/2010. Disponivel em: $<$ http://www.conteudojuridico.com.br/?artigos\&ver=2.26586>. Acesso em: 24 ago. 2017.
} 
consolidando nos tribunais brasileiros a partir da aplicação de indenizações ex officio pelos magistrados, com base no art. 404, PU, do CC, às empresas reincidentes no cometimento de práticas que violam a legislação trabalhista - como o pagamento de salários irrisórios, não recolhimento de FGTS, não concessão de intervalos intra e entre jornadas, não fornecimento de EPIs, submissão do empregado a condições degradantes, dentre outros atos ilícitos -, posto que tais condutas favorecem a concorrência desleal entre corporações mediante a depreciação do trabalhador. ${ }^{10}$

O parágrafo único, do art. 404, do CC, passa então a ser utilizado como um instrumento para se fundamentar indenização suplementar por motivo de Dumping Social que será - comumente - destinada ao Fundo de Amparo aos Trabalhadores (FAT), tendo em vista o seu caráter transindividual. Nesse liame, para simples conferência, segue o mencionado dispositivo e respectivo precedente de aplicação de nosso Tribunal Regional do Trabalho da $1^{\text {a }}$ Região:

Art. 404. As perdas e danos, nas obrigações de pagamento em dinheiro, serão pagas com atualização monetária segundo índices oficiais regularmente estabelecidos, abrangendo juros, custas e honorários de advogado, sem prejuízo da pena convencional.

Parágrafo único. Provado que os juros da mora não cobrem o prejuízo, e não havendo pena convencional, pode o juiz conceder ao credor indenização suplementar. - (grifo nosso)

AÇÃO CIVIL PÚBLICA. -DUMPING SOCIAL-. DANO À SOCIEDADE. INDENIZAÇÃO SUPLEMENTAR. As agressões reincidentes e inescusáveis aos direitos trabalhistas geram um dano à sociedade, pois com tal prática desconsidera-se, propositalmente, a estrutura do Estado social e do próprio modelo capitalista com a obtenção de vantagem indevida perante a concorrência. A prática, portanto, reflete o conhecido -dumping social-, motivando a necessária reação do Judiciário Trabalhista para corrigi-la. $\mathrm{O}$ dano à sociedade configura ato ilícito, por exercício abusivo do direito, já que extrapola limites econômicos e sociais, nos exatos termos dos artigos 186, 187 e 927 do Código Civil. Encontra-se no artigo 404, parágrafo único, do Código Civil, o fundamento de ordem positiva para impingir ao agressor contumaz uma indenizacão suplementar, como, aliás, já previam os artigos 652 , d, e $832, \S 1^{\circ}$, da CLT $-1^{\text {a }}$ Jornada de Direito Material do Trabalho - ENUNCIADO 04.

${ }^{10}$ CHAVES, Maria Cláudia Gomes. Dumping social como fator de precarização das relações de trabalho. In: Conteudo Juridico, Brasilia-DF: 16/04/2010. Disponivel em: $<$ http://www.conteudojuridico.com.br/?artigos\&ver=2.26586>. Acesso em: 24 ago. 2017. 
(TRT-1 - RO: 00001458820135010053 RJ, Relator: Edith Maria Correa Tourinho, Data de Julgamento: 17/12/2013, Oitava Turma, Data de Publicação: 13/01/2014) - (grifos nossos)

Frisa-se, entretanto, que a condenação ex officio em indenizações suplementares vem sendo rejeitada e reformada pelo TST sob o argumento de julgamento extra petita e violação ao princípio da ampla defesa, conforme se depreende do seguinte acórdão:

RECURSOS DE REVISTA. DUMPING SOCIAL. INDENIZAÇÃO. CONDENAÇÃO EX OFFICIO. PRINCÍPIOS DA AMPLA DEFESA E DO CONTRADITÓRIO. JULGAMENTO EXTRA PETITA 1. A Constituição Federal garante aos litigantes em processo judicial o exercício do contraditório e da ampla defesa, com os meios e recursos a ela inerentes (art. $5^{\circ}, \mathrm{LV}, \mathrm{da} \mathrm{CF}$ ). 2. Nos termos do art. 128 do CPC, o Juiz deverá decidir a lide nos limites em que foi proposta, sendo-lhe vedado conhecer de questões não suscitadas, para cujo conhecimento a lei exige a iniciativa das partes. 3. Acórdão regional que condena a empregadora, de ofício, ao pagamento de indenização por dumping social, não obstante a ausência de pedido e de oportunidade para a parte expor suas razões em contraditório e exercer a ampla defesa, viola a ordem constitucional vigente, bem como extrapola os limites da lide. 4. Recursos de revista das Reclamadas de que se conhece e a que se dá provimento .

(TST - RR: 28999320125150070, Relator: João Oreste Dalazen, Data de Julgamento: 02/12/2015, 4 a Turma, Data de Publicação: DEJT 18/12/2015) (grifo nosso)

Outrossim, compete ressaltar, por oportuno, que as empresas possuem a função social, ou melhor, um dever social de favorecer o crescimento socioeconômico da região e dos indivíduos pertencentes à comunidade em que estão inseridas. Por conseguinte, o cuidado com o meio ambiente, o respeito aos interesses da sociedade, o comprometimento com os consumidores e fornecedores, a valorização do trabalhador e a manutenção da lealdade concorrencial são compromissos intrínsecos à atividade desenvolvida, não somente a objetivação ao lucro.

Em outras palavras, “(...) o conceito de função social da empresa engloba a ideia de que esta não deve visar somente o lucro, mas também preocupar-se com os reflexos que suas decisões têm perante a sociedade, seja de forma geral, incorporando ao bem privado uma utilização voltada 
para a coletividade; ou de forma específica, trazendo realização social ao empresário e para todos aqueles que colaboraram para alcançar tal fim."11

Convém ainda mencionar que tal comprometimento necessário da empresa com a sociedade encontra base legal na Lei das Sociedades Anônimas - Lei n ${ }^{\circ} 6.404 / 1976$, senão vejamos:

Art. 116. Parágrafo único. O acionista controlador deve usar o poder com o fim de fazer a companhia realizar o seu objeto e cumprir sua funcão social, e tem deveres e responsabilidades para com os demais acionistas da empresa, os que nela trabalham e para com a comunidade em que atua, cujos direitos e interesses deve lealmente respeitar e atender. - (grifo nosso)

Por conseguinte, é certo dizer que o objetivo do reconhecimento do Dumping Social ultrapassa os direitos individuais do trabalhador agredido, tendo por foco a compensação da coletividade que foi prejudicada pela conduta da empresa em face ao seu desprezo ao cumprimento da sua função social, vez que a sonegação de direitos trabalhistas por ela perpetrada afeta diretamente todos os trabalhadores que pertencem ao seguimento violentado, bem como, todas as empresas que competem no setor, e indiretamente, os interesses da sociedade em sua integralidade.

No caso das grifes, a categoria de produção onde mais se verifica o uso de mão de obra escrava é relacionada à confecção das roupas, o que representa um dos componentes de maior peso no custo da mercadoria.

Nesse liame, o uso de mão de obra análoga à escrava na estrutura responsável pelo corte e costura das roupas representa indicação de ganho expressivo na competitividade para a venda de roupas, tendo em vista que o custo mínimo no pagamento de serviços de costura reflete um preço

${ }^{11}$ CARNEIRO, Paloma Torres. Função social da empresa. In: Ambito Jurídico, Rio Grande, XIV, n. 92, set 2011. Disponível em: $<$ http://www.ambitojuridico.com.br/site/index.php?n_link=revista_artigos_leitura\&artigo_id=10318>. Acesso em: 17 ago. 2015. 
mínimo na venda de produtos inalcançável por outras empresas do mesmo setor que seguem regularmente a legislação trabalhista. ${ }^{12}$

12 BRASIL. Ministério Público do Trabalho. Procuradoria Regional do Trabalho da 2a Região. Ação Civil Pública. Réu: M5 Indústria e Comércio Ltda. 2014. Disponível em: $<$ http://reporterbrasil.org.br/documentos/acp-mofficer.pdf>. Acesso em 14 jul. 2017 


\section{PARTE II - UMA BREVE ANÁLISE SOBRE O TRABALHO DECENTE E AS CONCEITUAÇÕES QUE ENVOLVEM O TRABALHO ANÁLOGO AO ESCRAVO}

\section{O Trabalho Decente}

Trabalho decente é aquele que se reveste das condições mínimas necessárias para a preservação dos Direitos Humanos do trabalhador, prestigiando-se a sua dignidade como qualidade intrínseca à pessoa humana, inalienável e irrenunciável.

Além de meio de subsistência digna para o obreiro e sua família, o trabalho também deve servir como instrumento para a realização pessoal do indivíduo.

Nesse liame, conforme ensinado pelo doutrinador José Claudio Monteiro $^{13}$, para que se possa falar em trabalho decente, é necessário considerar um conjunto mínimo de direitos necessários à preservação da dignidade do trabalhador. Para isso, devemos fazer uma leitura integrada da nossa CLT em atenção à Constituição Cidadã e a certas normas internacionais que refletem uma preocupação convergente sobre o tema em apreço.

A CRFB merece aqui destaque por apresentar em seu texto extenso rol de preceitos fundamentais a serem seguidos na busca pelo pleno emprego.

A título de ilustração, convém mencionar o reconhecimento da dignidade humana e do valor social do trabalho como bases do Estado Democrático de Direito (art. $1^{\circ}$, inc. III e IV); a erradicação da pobreza e marginalização, bem como, a redução das desigualdades sociais e regionais

\footnotetext{
${ }^{13}$ BRITO FILHO, José Cláudio Monteiro de. Trabalho Decente: Análise jurídica da exploração do trabalho - Trabalho escravo e outras formas de trabalho indigno. $4^{\text {a }}$ ed. São Paulo: LTr, 2016.
} 
como objetivos fundamentais da República (art. $3^{\circ}$, inc. III); a defesa da inviolabilidade do direito à vida, à liberdade, à igualdade e à segurança (art. $5^{\circ}$, caput,); a vedação à tortura ou ao tratamento desumano ou degradante (art. $5^{\circ}$, inc. III); a defesa à inviolabilidade da intimidade, da vida privada, da honra e da imagem (art. $5^{\circ}$, inc. X); a liberdade do exercício de qualquer trabalho, ofício ou profissão como direitos consagrados (art. $5^{\circ}$, inc. XIII); a defesa do direito à liberdade de locomoção (art. $5^{\circ}$, inc. XV); a função social da propriedade como instituto consolidado (art. $5^{\circ}$, inc. XXIII); a proibição de se impor a pena de trabalhos forçados ou cruéis (art. $5^{\circ}$, inc. XLVI); a vedação à prisão por motivos de dívida (art. $5^{\circ}$, inc. XLVI); a proteção contra o desemprego (art. $7^{\circ}$, inc. II); a condenação de qualquer tipo de discriminação e o prestígio à igualdade (art. $7^{\circ}$, inc. XX, XXX, XXI e XXXII); a preocupação pela justa remuneração (art. $7^{\circ}$, inc. IV); a necessidade de limitação de jornada de trabalho (art. $7^{\circ}$, inc. XIII e XIV); a exigência de concessão de períodos de repouso (art. $7^{\circ}$, inc. XV e XVII) e, por fim, a proibição do trabalho infantil (art. $7^{\circ}$, inc. XXXIII).

Para interpretação conjunta aos direitos acima elencados e àqueles presentes no diploma trabalhista pátrio, citamos também as normas internacionais que apresentam um maior compromisso na defesa do trabalho digno.

Temos a Convenção das Nações Unidas sobre Escravatura (1926) emendada pelo Protocolo de 1953 e a Convenção Suplementar sobre a Abolição da Escravatura (1956), a Declaração dos Direitos Humanos e seus direitos concentrados nos artigos XXIII e XXIV, que tratam mais especificamente da matéria trabalhista, o Pacto Internacional dos Direitos Econômicos, Sociais e Culturais, ratificado pelo Brasil e internalizado sob a forma do Decreto $n^{\circ}$ 591/1992, que traz noções de trabalho justo em seus artigos $6^{\circ}$ e $7^{\circ}$, e as Convenções da Organização Internacional do Trabalho (OIT), particularmente aquelas que cuidam da vedação ao trabalho forçado (29 e 105), da liberdade sindical (87 e 98), do repúdio à discriminação (100 
e 111) e da proibição à prestação de serviços abaixo de uma idade mínima (138 e 142).

Dada a sua elevada importância, convém destacar os artigos da Declaração Universal dos Direitos Humanos que consagram os direitos instrínsecos ao trabalhador:

Art. $23^{\circ}$

1. Toda a pessoa tem direito ao trabalho, à livre escolha do trabalho, a condições equitativas e satisfatórias de trabalho e à proteção contra o desemprego.

2. Todos têm direito, sem discriminação alguma, a salário igual por trabalho igual.

3. Quem trabalha tem direito a uma remuneração equitativa e satisfatória, que lhe permita e à sua família uma existência conforme com a dignidade humana, e completada, se possível, por todos os outros meios de proteção social.

4. Toda a pessoa tem o direito de fundar com outras pessoas sindicatos e de se filiar em sindicatos para defesa dos seus interesses.

Art. $24^{\circ}$

Toda a pessoa tem direito ao repouso e aos lazeres, especialmente, a uma limitação razoável da duração do trabalho e as férias periódias pagas.

O arcabouço normativo ora enunciado nos permite, dessa forma, definir os (9) direitos fundamentais do "homem-trabalhador", capazes de protegê-lo da exploração desenfreada pelo capital, assegurando condições dignas para o exercício de sua profissão. ${ }^{14}$

Como base para todos os demais direitos, citamos, inicialmente, o (1) Direito ao Trabalho, que se constitui no dever do Estado em criar condições para que o trabalhador, parte mais vulnerável da relação, não tenha sua vontade mitigada pela imposição da superioridade (via de regra econômica) do seu empregador, de forma a se alcançar um equilíbrio entre as partes, propiciando que o obreiro exerça seu ofício de forma honesta, garantindo sua subsistência e de sua família.

Em seguida, podemos listar todos os demais direitos mínimos que ${ }^{14}$ BRITO FILHO, José Cláudio Monteiro de. Trabalho Decente: Análise jurídica da exploração do
trabalho - Trabalho escravo e outras formas de trabalho indigno. $4^{\mathrm{a}}$ ed. São Paulo: LTr, 2016. 
podem ser extraídos deste primeiro, quais sejam: (2) Direito à Liberdade de Escolha do Trabalhador, o que veda qualquer forma de sujeição do empregado ao exercício não espontâneo de seu ofício; (3) Direito à Igualdade de Oportunidades, em que se prestigia a igualdade material para o acesso ao trabalho, bem como, no exercício da profissão, sem discriminações de qualquer natureza, seja de gênero, sexual, econômica, religiosa, por idade, dentre outras; (4) Direito a Condições de Saúde e Segurança no Trabalho, buscando-se um ambiente de trabalho que priorize a vida do trabalhador; (5) Direito à Remuneração Justa, em que a contraprestação deve ser economicamente compatível com o trabalho prestado, respeitando-se um percentual mínimo para o pagamento in natura; (6) Direito à Jornada de Trabalho não Exaustiva, em que se observe a limitação de jornada, bem como, que se conceda períodos de repouso suficientes para a recuperação física e psicológica do trabalhador; (7) Direito à Fixação de Idade Mínima para o Trabalho, promovendo-se a vedação ao trabalho infantil, sendo proibida a prática de ofício por menores de 16 anos, salvo na figura de aprendiz aos 14 anos em circunstâncias não insalubres e que respeitem a sua condição de vulnerabilidade; (8) Direito à Liberdade Sindical, proporcionando a reunião de trabalhadores em associações que busquem continuamente melhores condições e uma maior paridade de forças com os que detêm os meios de produção; e (9) Direito à Seguridade Social, como a proteção em caso de desemprego, acidentes de trabalho, doenças ocupacionais e aposentadoria.

Tais direitos nada mais representam que a essência do que se entende por trabalho digno, de maneira que a ausência de qualquer um deles torna precária a prática laboral, sujeitando o indivíduo a condições aviltantes para o exercício da profissão, o que trespassa a esfera individual, agredindo a coletividade como um todo, vez que nossa sociedade se encontra fundada no valor social do trabalho e no princípio da dignidade humana. 


\section{O Trabalho Análogo ao Escravo - Definição, Conceitos e Modos de Execução}

Inicialmente, cumpre aqui esclarecer que o uso da expressão "trabalho escravo" para a configuração do crime objeto de estudo não se apresenta como a mais adequada para definir as práticas de superexploração perpetradas na contemporaneidade, tendo em vista que a condição de escravo foi juridicamente abolida desde 1988, com o advento da Lei Áurea, não se podendo sujeitar nenhum indivíduo ao status de "propriedade" de um terceiro em pleno séc. XXI.

Nesse sentido, o crime certo a ser considerado como tal é aquele denominado de plágio, cujo tipo penal consiste em reduzir alguém à condição análoga à de escravo, presente no art. 149 do CP. ${ }^{15}$

A noção de plágio (plagium) possui precedentes históricos no Direito Romano, onde se buscava punir a conduta de conduzir homem livre por direito à escravidão (chamada de escravidão indevida), em cenário distinto daquele ostentado na sujeição compulsória do indivíduo que era visto desde sua origem, seja por dívida, por prisão em guerra ou por razões étnicas, como animal ou coisa passível de escravidão legalizada. ${ }^{16}$

Não obstante o ora elucidado, por a expressão "trabalho escravo" e suas variantes possibilitarem uma maior assimilação de ideias, utilizaremos neste estudo os termos "trabalho escravo contemporâneo", "trabalho forçado", "trabalho em condições degradantes", dentre outros, objetivando a representação de uma mesma realidade: o trabalho análogo ao escravo

\footnotetext{
${ }^{15}$ MELO, Luís Antônio Camargo de. Premissas para um eficaz combate ao trabalho escravo. Revista do Ministério Público do Trabalho, Brasília, ano XIII, n. 26. São Paulo: Ltr, 2003. p. 1133. Disponível em: <http://www.anpt.org.br/attachments/article/2720/Revista\%20MPT\%20\%20Edi\%C3\%A7\%C3\%A3o\%2026.pdf>. Acesso em 04 fev. 2017.

${ }^{16}$ ANDRADE, Carlos Eduardo Almeida Martins de. Do crime de redução à condição análoga à de escravo na legislação, doutrina e jurisprudência. In: Âmbito Jurídico, Rio Grande, XV, n. 98, mar 2012. Disponível em:

$<\mathrm{http} / / / \mathrm{www} . a m b i t o j u r i d i c o . c o m . b r / s i t e / ? \mathrm{n}$ _link=revista_artigos_leitura\&artigo_id=1118 $3 \&$ revista_caderno $=3>$. Acesso em 20 set. 2017 .
} 
presente nos dias de hoje. ${ }^{17}$

\subsection{O Trabalho Escravo Típico e o Contemporâneo}

Comumente nós associamos o trabalho escravo à figura dos escravos acorrentados e chicoteados no tempo do Brasil Colônia, o que afasta nossa sensibilidade quanto aos escravos encontrados nos tempos modernos.

O trabalho escravo contemporâneo se manifesta de forma singular daquele trabalho escravo típico que contava com a presença de grilhões, capatazes e senzalas.

Podemos dizer que o trabalho escravo típico era objeto de política de Estado, por meio do qual o ser humano (e não sua força de trabalho) era vendido como mercadoria a ser explorada, sendo disciplinado por meio de lei e mantido através da coerção direta dos proprietários e do próprio governo.

Em panorama oposto, no Estado contemporâneo, o trabalho escravo é formalmente proibido pelo Brasil, não sendo os próprios obreiros a mercadoria, mas sim sua força de trabalho, de modo que o labor exercido em condições de extrema precariedade ocorre veladamente por meio da coerção dissimulada empregada pelos tomadores de serviço, não se encontrando com tanta frequência a violência comum à escravidão típica dentro desta atual logística de abusiva sujeição do trabalhador. ${ }^{18}$

Convém assim dizer, que a escravidão contemporânea nada mais é que um dos "efeitos colaterais" de um sistema capitalista desregulado, tal

\footnotetext{
17 MELO, Luís Antônio Camargo de. Premissas para um eficaz combate ao trabalho escravo. Revista do Ministério Público do Trabalho, Brasília, ano XIII, ${ }^{\circ}$. 26. São Paulo: Ltr, 2003. p. 1133. Disponível em: <http://www.anpt.org.br/attachments/article/2720/Revista\%20MPT\%20\%20Edi\%C3\%A7\%C3\%A3o\%2026.pdf>. Acesso em 04 fev. 2017.

${ }^{18}$ FILGUEIRAS, Vitor Araújo. Trabalho análogo ao escravo e o limite da relação de emprego: Natureza e disputa na regulação do Estado. In: PRADO, Adonia Antunes; GALVÃO, Edna Maria; FIGUEIRA, Ricardo Rezende (Orgs). A Universidade Discute a Escravidão Contemporânea: Práticas e Reflexões. $1^{\mathrm{a}}$ ed. Rio de Janeiro: Mauad X, 2015. p. 133-156.
} 
como a miséria e a fome.

De forma mais esquemática, apresentamos quadro comparativo de Kevin Bales que busca diferenciar ambas as formas de escravidão sucintamente:

\section{Diferenças entre antiga e nova escravidão ${ }^{19}$}

\begin{tabular}{|c|c|}
\hline Antigas formas de escravidão & Novas formas de escravidão \\
\hline Propriedade legal permitida & Propriedade legal proibida \\
\hline Custo de aquisição alto & Custo de aquisição muito baixo \\
\hline Lucros baixos & Lucros muito altos \\
\hline Escassez de potenciais escravos & $\begin{array}{c}\text { Superoferta de potenciais } \\
\text { escravos }\end{array}$ \\
\hline Relacionamento de longo prazo & Relacionamento de curto prazo \\
\hline Escravo é bem a ser mantido & Escravo é descartável \\
\hline Diferenças étnicas importantes & $\begin{array}{c}\text { Diferenças étnicas menos } \\
\text { importantes }\end{array}$ \\
\hline
\end{tabular}

Fato é que a característica determinante da atual forma de superexploração do trabalhador é a redução deste indivíduo à condição análoga à escrava por conta de sua hipervulnerabilidade no meio social em que se encontra, não mais por questões propriamente étnicas - embora tal característica também possa contribuir para a vulnerabilidade do sujeito.

Além disso, podemos dizer que a nova escravidão trouxe a evolução do objeto essencial a ser tutelado, de modo que, atualmente, temos a necessidade de que a proteção vá além da liberdade individual, abarcandose todos os bens tutelados pelo princípio da dignidade humana.

Quanto à apontada necessidade de ampliação do bem jurídico a ser protegido, o trecho a seguir nos mostra sua aplicação em uma sociedade que ilusoriamente considera seus trabalhadores sujeitos a condições degradantes

19 TIMÓTEO, Gabrielle Loiuse Soares. Trabalho em condições análogas à escravidão na sociedade de consumo. In: PRADO, Adonia Antunes; GALVÃO, Edna Maria; FIGUEIRA, Ricardo Rezende (Orgs). A Universidade Discute a Escravidão Contemporânea: Práticas e Reflexões. $1^{\mathrm{a}}$ ed. Rio de Janeiro: Mauad X, 2015. p. 247 - Quadro comparativo de K.Bales, 2004, adaptado pela Autora. 
como cidadãos livres:

É análogo, pois são as mesmas condições, mas com base em outros mecanismos de coerção. Isso não torna o fato menos grave, pelo contrário, torna o fenômeno mais cruel, pois a coercão impessoal do mercado sugere que o trabalhador aceita a degradância por opcão, pois pretensamente livre. ${ }^{20}$ (grifo nosso)

Por conseguinte, é certo dizer que o Brasil não deixou de ser um país escravocrata, muito pelo contrário, ele vive uma "escravocracia camuflada" em que não mais somente negros estão fadados ao trabalho em condições de extrema precariedade, como também brancos, pobres, imigrantes, mulheres e crianças experimentam o trabalho análogo ao escravo nas mais diversas regiões do país. ${ }^{21}$

\subsection{O art. 149 do Código Penal e a Ampliação dos modos de execução do trabalho escravo}

Em 11 de dezembro de 2003, foi promulgada a Lei $n^{\circ} 10.803$, que trouxe nova redação ao crime disciplinado pelo art. 149 do CP e adaptou nossa legislação pátria ao conceito contemporâneo internacional de trabalho análogo ao escravo, definindo um marco na proteção de direitos fundamentais do trabalhador brasileiro.

Para uma breve conferência, segue o dispositivo antes e após a alteração proporcionada pela Lei $n^{\circ} 10.803 / 2003$ :

\footnotetext{
ANTES DA LEI $n^{\circ} \mathbf{1 0 . 8 0 3 / 2 0 0 3}$

Redução a condição análoga à de escravo

Art. 149. Reduzir alguém a condição análoga à de escravo:

Pena - reclusão, de dois a oito anos.
}

\footnotetext{
${ }^{20}$ FILGUEIRAS, Vitor Araújo. Trabalho análogo ao escravo e o limite da relação de emprego: Natureza e disputa na regulação do Estado. In: PRADO, Adonia Antunes; GALVÃO, Edna Maria; FIGUEIRA, Ricardo Rezende (Orgs). A Universidade Discute a Escravidão Contemporânea: Práticas e Reflexões. $1^{\mathrm{a}}$ ed. Rio de Janeiro: Mauad X, 2015. p. 147.

21 SANTOS, Ronaldo Lima dos. A escravidão por dívidas nas relações de trabalho no Brasil contemporâneo. Revista do Ministério Público do Trabalho, Brasília, ano XIII, n ${ }^{\circ}$ 26. São Paulo: Ltr, 2003. p. 47-66. $\quad$ pisponível $<$ http://www.anpt.org.br/attachments/article/2720/Revista\%20MPT\%20\%20Edi\%C3\%A7\%C3\%A3o\%2026.pdf>. Acesso em 04 fev. 2017.
} 


\section{DEPOIS DA LEI ${ }^{\circ} 10.803 / 2003$}

Art. 149. Reduzir alguém a condição análoga à de escravo, quer submetendo-o a trabalhos forçados ou a jornada exaustiva, quer sujeitando-o a condições degradantes de trabalho, quer restringindo, por qualquer meio, sua locomoção em razão de dívida contraída com o empregador ou preposto:

Pena - reclusão, de dois a oito anos, e multa, além da pena correspondente à violência.

$\S 1$ o Nas mesmas penas incorre quem

I - cerceia o uso de qualquer meio de transporte por parte do trabalhador, com o fim de retê-lo no local de trabalho;

II - mantém vigilância ostensiva no local de trabalho ou se apodera de documentos ou objetos pessoais do trabalhador, com o fim de retê-lo no local de trabalho.

$\S 2$ o A pena é aumentada de metade, se o crime é cometido:

I - contra criança ou adolescente;

II - por motivo de preconceito de raça, cor, etnia, religião ou origem.

É possível notar que a redação foi ampliada, de modo que o tipo penal compreendido passou de uma forma sintética, aberto a interpretações diversas (restritivas ou não), para uma forma analítica, que trouxe sete tipos de modos de execução da superexploração do trabalhador.

Nesse liame, nasce uma perspectiva além daquela do trabalho forçado clássico como meio de escravidão contemporânea, ao passo que o núcleo de proteção do indivíduo deixou de ser a liberdade, passando-se a englobá-la dentro do conceito de dignidade humana.

Ou seja, o que temos é uma busca pela preservação da dignidade do trabalhador, que contempla, dentre muitos outros bens jurídicos a serem tutelados, a liberdade, de modo que a superexploração da miséria e das necessidades do ser humano em âmbito laboral passa a ser sim considerada uma forma de reduzi-lo a condições análogas à escravidão.

Ressalta-se que apesar de o núcleo de proteção ter evoluído da liberdade para a dignidade do indivíduo, é importante deixar claro que o conceito de liberdade em essência permanece sendo preservado em quaisquer dos sete meios de execução a serem combatidos, vez que, em todos eles, é possível identificar uma relação de sujeição (diferente daquela de subordinação jurídica) do empregado ao pleno domínio do empregador 
que, direta ou indiretamente, fere a liberdade da pessoa.

O absoluto controle de um indivíduo sobre o outro dentro do ambiente de trabalho sem a limitação do Poder Diretivo do empregador pelos princípios constitucionais que protegem a liberdade, a intimidade e a dignidade do obreiro, é a essência do tipo penal em análise, merecendo destaque na sua identificação.

Adentrando-se propriamente aos meios de execução do trabalho análogo ao escravo, podemos dividi-los em duas categorias, as típicas (convencionais) e aquelas entendidas como igualmente ilícitas por equiparação. ${ }^{22}$

O primeiro modo de execução típico de trabalho semelhante ao escravo, qual seja, o trabalho forçado, tem por sua característica determinante a prestação compulsória do labor, anulando-se a vontade daquele que detém a mão de obra, transformando-o em máquina.

Em seguida, temos o segundo modo de execução, a jornada exaustiva de trabalho, que apresenta como peculiaridade o exaurimento físico-mental do trabalhador através de um ritmo de trabalho imposto pelo tomador de serviços que compromete sua saúde e propicia acidentes de trabalho.

Importante frisar que a submissão do obreiro a jornadas excessivas deverá ocorrer por vícios de vontade deste último, não sendo a limitação de jornada disciplinada por lei parâmetro definitivo para que se determine se o cumprimento ao tempo previsto para certa atividade, mesmo que legalmente prescrito, seja capaz de afastar a jornada excessiva e prejudicial ao trabalhador. ${ }^{23}$

\footnotetext{
${ }^{22}$ BRITO FILHO, José Cláudio Monteiro de. Trabalho Decente: Análise jurídica da exploração do trabalho - Trabalho escravo e outras formas de trabalho indigno. $4^{\mathrm{a}}$ ed. São Paulo: LTr, 2016.

${ }^{23}$ BRITO FILHO, José Cláudio Monteiro de. Trabalho Decente: Análise jurídica da exploração do trabalho - Trabalho escravo e outras formas de trabalho indigno. $4^{\mathrm{a}}$ ed. São Paulo: LTr, 2016.
} 
Ainda, citamos a categoria de condições degradantes de trabalho, que se resume na sujeição do obreiro a circunstâncias humilhantes de trabalho e remuneração. Por se tratar de hipótese que possa ser considerada, por alguns, de muita abstração, convém aqui mencionar, a título de exemplo, a falta de ambiente de trabalho salubre e seguro, a cobrança pelo fornecimento de equipamentos e materiais de ofício, a falta ou o fornecimento de alimentação e água em condições impróprias para o consumo, a disposição de alojamentos precários, dentre outros.

Podemos também falar do modelo da escravidão por dívida contraída, comumente chamada pela doutrina de "servidão por dívida", truck system, ou, até mesmo, "sistema de barracão", que nada mais é do que impedir o trabalhador de deixar o local de trabalho por ter-se endividado compulsoriamente com o tomador de serviços ou com o aliciador contratado por este, apelidado de "gato"/"zangão"/"turmeiro", sendo tal dívida normalmente composta pela passagem para o local da exploração, pelo pagamento de outras dívidas que por ventura o trabalhador e sua família possuam no local do aliciamento, pelas despesas com a nova moradia e pelos custos com instrumentos de trabalho, roupas e suprimentos adquiridos em comércio próprio do patrão, de modo que o débito assumido passa a crescer de forma vertiginosa, com juros exorbitantes ou por meio de fraudes, desproporcional ao que fora gasto pelo trabalhador, sendo praticamente impossível de ser saldado.

Por se tratar de dívida de difícil pagamento, o trabalho é baseado na intimidação pelo tomador de serviços, que ocupa a área de realização de atividades com uma vigilância ostensiva, além de usar certos trabalhadores que tentaram escapar de seu sistema como exemplo, aplicando-lhes graves sanções.

Destaca-se que a licitude da dívida adquirida não descaracteriza o modo de execução quando o empregador permanece constrangendo moral 
ou fisicamente o indivíduo.

Por fim, temos as modalidades de trabalho escravo por equiparação, cujo objetivo é comum a todas elas: reter o trabalhador no local de trabalho.

Nesse sentido, o trabalho escravo por equiparação pode ser verificado quando o tomador de serviços (a) nega aos seus trabalhadores acesso a meios de transporte para o deslocamento "trabalho-casa", como uma maneira de viciar a vontade dos trabalhadores; (b) mantém vigilância ostensiva no ambiente de trabalho, coagindo-os a permanecer no mesmo local; e (c) é usada a retenção de documentos e objetos pessoais do trabalhador como artifício para negar seus direitos e mantê-lo sob a condição de superexploração.

Convém salientar que na caracterização do trabalho escravo contemporâneo encontramos sempre a presença de vícios de vontade do trabalhador explorado, seja no início do aliciamento do obreiro, no começo da prestação de serviços, durante o contrato de trabalho ou no término desta relação.

Assim sendo, registra-se ser imprescindível a coação do trabalhador para permanecer prestando seus serviços, a qual poderá ser moral, psicológica e física. $^{24}$

A coação moral tende a ocorrer, por exemplo, nos casos de escravidão por dívidas fraudulentas, em que o tomador de serviços se aproveita da falta de instrução de seu empregado, ou, até mesmo, do senso de honra desse em relação ao pagamento de suas obrigações, para “acorrentá-1o" ao trabalho.

Por outro lado, a coação psicológica, tem por principal instrumento a

${ }^{24}$ MELO, Luís Antônio Camargo de. Premissas para um eficaz combate ao trabalho escravo. Revista do Ministério Público do Trabalho, Brasília, ano XIII, ${ }^{\circ}$. 26. São Paulo: Ltr, 2003. p. 1133. Disponível em: <http://www.anpt.org.br/attachments/article/2720/Revista\%20MPT\%20\%20Edi\%C3\%A7\%C3\%A3o\%2026.pdf>. Acesso em 04 fev. 2017. 
instauração do medo de represálias físicas no ambiente de trabalho, as quais serão deflagradas contra o trabalhador que não seguir as ordens do tomador de serviços.

Geralmente, tal coação se dá por meio da vigilância desnecessariamente armada dos trabalhadores, da distância do local de prestação de serviços da cidade, bem como, da retenção de documentos seguida de ameaça de denúncia quanto à situação ilegal dos imigrantes trabalhadores no Brasil.

Finalmente, temos a coação propriamente física, em que os trabalhadores "rebeldes" ou "ineficientes" são sujeitados a castigos físicos, servindo muitas vezes de exemplo para os demais trabalhadores.

Nesse liame, podemos também chamar de trabalho análogo ao escravo aquele em que o trabalhador é submetido a quaisquer das três coações descritas para viciar a sua vontade, sendo - mesmo que veladamente - obrigado a permanecer laborando, ainda que no início tenha livremente ajustado a prestação de serviços.

Portanto, resta claro que obreiro não se enquadrará em condição análoga ao de trabalhador escravo quando, minimamente, tiver garantida a sua capacidade de autodeterminação.

Cumpre esclarecer, que o vício de vontade sofrido pelos trabalhadores explorados tem repercussões que ultrapassam a pessoa do empregado e atingem de forma destrutiva sua família, culminando, por exemplo, na privação de seus filhos à educação institucional, na sujeição da família a adquirir doenças contagiosas quando convivem no mesmo alojamento precário e superlotado que o trabalhador, na apreensão de documentos dos familiares, no desamparo à família em caso de morte ou doença do obreiro, na não incomum escravização de filhos e cônjuges, 
dentre outras situações. ${ }^{25}$

E vai além, o vício de vontade sofrido pelo trabalhador, na realidade, é suportado por toda a coletividade, tendo em vista que a proibição à escravidão é um direito difuso que alcança a todos, bastando, para isso, sua condição humana.

Ainda assim, a prática em referência ocorre de forma tão reiterada que já possui um "procedimento padrão", sendo possível estruturar a cadeia de condutas regularmente perpetradas contra o sujeito hipervulnerável que, diante da ausência de políticas públicas capazes de prevenir, punir e remediar o trabalho escravo, se vê dentro de um ciclo vicioso de superexploração.

Em síntese, podemos dizer que o procedimento de exploração do trabalhador ocorre - respeitando-se as particularidades de cada caso - do seguinte modo: 1. Prepostos do tomador de serviços, chamados de "gatos", "zangões" ou "turmeiros", realizam o recrutamento de trabalhadores oferecendo propostas tentadoras de trabalho em locais distantes de sua cidade de origem, com promessas de melhores condições de vida e salários expressivos; 2. O preposto, durante a arregimentação, tende a não exigir documentos de identificação ou carteira de trabalho, contudo, quando apresentado certo documento, este é retido, criando-se um vínculo de dependência do trabalhador para com o aliciador e o tomador de serviços; 3 . $\mathrm{O}$ preposto costuma emprestar certa quantia em dinheiro para que o trabalhador recém aliciado pague suas dívidas e de sua família no local de origem, além de também pagar o transporte deste trabalhador para o local de prestação de serviços sob título de crédito, favorecendo a escravidão por dívidas; 4. Quando a prestação de serviços se inicia, o trabalhador passa a

\footnotetext{
25 SANTOS, Ronaldo Lima dos. A escravidão por dívidas nas relações de trabalho no Brasil contemporâneo. Revista do Ministério Público do Trabalho, Brasília, ano XIII, $\mathrm{n}^{\circ}$. 26. São Paulo: Ltr, 2003. p. 47-66. $\quad$ pisponível $<$ http://www.anpt.org.br/attachments/article/2720/Revista\%20MPT\%20\%20Edi\%C3\%A7\%C3\%A30\%2026.pdf>. Acesso em 04 fev. 2017.
} 
ser submetido a condições degradantes de trabalho, jornadas exaustivas, recebendo, muitas vezes pagamento in natura e sendo cobrado pelos equipamentos que utiliza e pelo custo do alojamento de trabalho; 5. A dívida contraída com o tomador de serviços, os documentos retidos ilegalmente e a coação física, moral e psicológica do trabalhador funcionam como ferramentas para a manutenção deste na relação precária de trabalho; 6. Em caso de descoberta do uso de trabalho análogo ao escravo por certo tomador de serviços, o trabalhador é resgatado; 7. Verificada a ausência de políticas públicas e mecanismos que fixem o trabalhador no local de origem, é possível que se confirme a reincidência do mesmo no sistema de trabalho escravo contemporâneo. ${ }^{26}$

Tais práticas violam, sobretudo, os princípios da intangibilidade salarial (art. 462, caput, da CLT) e da irredutibilidade do salário (art. $7^{\circ}$, inc. VI, da CRFB), a vedação à prática do "sistema de barracão", a limitação do pagamento do salário em utilidades (art. 82 da CLT), dentre outros direitos trabalhistas a serem melhor exemplificados em capítulo próprio que contempla a análise de caso concreto.

Ademais, cumpre ainda mencionar a ligação direta do art. 149 do CP com demais tipos penais previstos no citado código, como o crime de exposição da vida ou saúde de outrem a perigo direto e iminente verificado no art. 132, ainda que decorrente do transporte em condições ilegais, conforme PU do mesmo artigo; o crime de constranger alguém à prática ou não de determinado ofício presente no inc. I do art. 197; o crime de frustração de direito assegurado por lei trabalhista descrito pelo caput do art. 203, bem como, aquele que trata da servidão por dívida, inc. I, e da manutenção compulsória do trabalhador no serviço por coação e retenção de documentos, inc. II; o crime de aliciamento de trabalhadores exposto nos

\footnotetext{
26 SANTOS, Ronaldo Lima dos. A escravidão por dívidas nas relações de trabalho no Brasil contemporâneo. Revista do Ministério Público do Trabalho, Brasília, ano XIII, n ${ }^{\circ}$ 26. São Paulo: Ltr, 2003. p. 47-66. Disponível $<$ http://www.anpt.org.br/attachments/article/2720/Revista\%20MPT\%20\%20Edi\%C3\%A7\%C3\%A30\%2026.pdf>. Acesso em 04 fev. 2017.
} 
arts. 206 e 207, e aquele que disciplina o tráfico de pessoas, presente o art. $149-\mathrm{A} .^{27}$

Destaca-se, por fim, que o último crime ora elencado, qual seja, o de tráfico de seres humanos, é a "porta de entrada" dos imigrantes ilegais - de maioria latino-americana - que hoje se encontram nos centros urbanos do nosso país submetidos a condições de trabalho análogas as verificadas na escravidão, valendo-se, dessa forma, de maior aprofundamento neste estudo monográfico.

\subsection{A Sujeição de Imigrantes ao Trabalho Análogo ao Escravo no Interior da Cadeia Produtiva da Indústria da Moda Brasileira}

No ano de 2013, pela primeira vez no Brasil, a maioria dos casos de resgate de trabalhadores em situação análoga à escrava ocorreu nos centros urbanos, principalmente em setores como a construção civil e a indústria têxtil. ${ }^{28}$

Só no estado de São Paulo, região que contempla o maior número de denúncias de trabalho escravo em oficinas, foram resgatados cerca de 1.529 trabalhadores em condições de superexploração entre os anos de 2003$2017^{29}$, sendo a grande maioria deles composta por imigrantes ilegais de países periféricos, especialmente latino-americanos.

Certo é que as magazines de vestuário viram no trabalhador imigrante uma oportunidade de alcançar o sucesso econômico pela sonegação de direitos trabalhistas, aproveitando-se da natural exclusão social sofrida por este tipo de sujeito ante a sua - comum - situação irregular no país.

\footnotetext{
27 SAKAMOTO, Leonardo (Org.). Comitê de Coordenação e Monitoramento do Pacto Nacional pela Erradicação do Trabalho Escravo. Cartilha das Confecções. In: Repórter Brasil. 2012. Disponível em: <http://reporterbrasil.org.br/documentos/pacto_web.pdf>. Acesso em 20 out. 2017.

${ }^{28}$ OIT. O trabalho forçado no Brasil. Disponível em: <http://www.ilo.org/brasilia/temas/trabalhoescravo/WCMS_393066/lang--pt/index.htm>. Acesso em 02 set. 2017.

29 MPT. Observatório Digital do Trabalho Escravo no Brasil. Disponível em: $<$ https://observatorioescravo.mpt.mp.br/>. Acesso em 06 ago. 2017.
} 
Para que seja possível tal aproveitamento, as grifes valem-se de arranjos próprios de subcontratação, a fim de diminuir os custos de sua produção, externalizar sua atividade de corte e costura e afastar do alcance da responsabilidade de suas marcas qualquer violação perpetrada contra "terceiros" (imigrantes que trabalham nas oficinas) por "terceiros" (fornecedores).

Normalmente, estas empresas tomam para si o dever de criação e marketing de seus produtos e transferem a atividade de confecção para fornecedores. Como estes últimos não costumam possuir larga capacidade produtiva, novamente temos a ocorrência da subcontratação, sendo agora de oficinas menores, chamadas de facções, muitas vezes clandestinas.

As oficinas clandestinas constituem a base da cadeia produtiva fast fashion e, contando com a fiscalização inadequada ou até mesmo inexistente das magazines, costumam "contratar" trabalhadores imigrantes sem documentação regular no país e sem a formalização de qualquer contrato de trabalho.

É a partir da citada lógica de subcontratação indiscriminada dentro do setor têxtil, que busca tirar proveito da vulnerabilidade social e econômica dos trabalhadores por meio de recorrentes processos de terceirização e quarteirização do processo produtivo $^{30}$, que é possível verificar a ocorrência dos diferentes modos de execução de trabalho análogo ao escravo conceituados no capítulo anterior.

A título de exemplo, citaremos aqui alguns casos de superexploração de imigrantes por certas marcas que configuraram tipos variados de trabalho escravo contemporâneo.

Como primeiro flagrante, recorremos ao caso da facção que produzia

\footnotetext{
${ }^{30}$ CABREIRA, Lucas Ferreira; WOLFF, Simone. Precarização e informalidade na indústria de confeç̧ões em Cianorte: Crise na tutela trabalhista. Disponível em: $<\mathrm{http} / / /$ www.estudosdotrabalho.org/texto/gt7/precarizacao.pdf>. Acesso em 17 set. 2017.
} 
peças para a rede varejista Marisa, registrada como Indústria de Comércio e Roupas CSV Ltda., onde foram apreendidos cadernos pelos auditores fiscais que continham anotações de supostas dívidas dos trabalhadores com o empregador da oficina, indicando obrigações de natureza claramente ilícita, bem como, a relação de salários em valores bem abaixo do piso da categoria à época do flagrante, que não possibilitariam o saldo das cobranças registradas, sendo evidente a servidão por dívida estabelecida, conforme trecho que se segue:

Foram apreendidos cadernos com anotações que remetem diretamente a cobrancas ilegais de passagens da Bolívia para o Brasil, a "taxas" não permitidas de despesas designadas com termos como "fronteira" e "documentos" - o que, segundo a fiscalização, consiste em "fortes indícios de tráfico de pessoas" -, ao endividamento por meio de vales e a descontos indevidos. Há registros de "salários" de R $\$ 202$ e de R \$247, menos da metade do salário mínimo ( $\mathrm{R} \$ 510)$ e menos de um terco do piso da categoria $(\mathrm{R} \$ 766){ }^{31}$ (grifos nossos)

A magazine Renner também foi alvo de fiscalização por auditores fiscais, momento em que foram encontradas evidências de trabalho análogo ao escravo nas facções que faziam parte de sua cadeia produtiva, a exemplo do trabalho em condições degradantes - que viola inúmeras normas de saúde e segurança - identificado não somente nas próprias oficinas, como também nos alojamentos em que residiam seus trabalhadores, senão vejamos:

A reportagem visitou o maior dos alojamentos, um edifício de quatro andares a
um quarteirão da oficina. No térreo, uma placa indica que ali funciona um templo
evangélico. Os mais de 20 trabalhadores e trabalhadoras, alguns com seus filhos,
se apertam nos três pavimentos superiores, espalhados por diminutos dormitórios
formados por divisórias de madeira, sob completa falta de higiene e
privacidade, risco de incêndio e explosão de botiiões de gás, e alimentos
armazenados em locais impróprios e cheios de insetos.
Uma rápida observação do ambiente é suficiente para constatar que o local é
repleto de soluções improvisadas. Os colchões estão em mau estado, não há
armários, objetos pessoais se acumulam em um só canto dos cômodos, e a
privacidade é preservada com toalhas, pedacos de papelão ou lonas nas

31 HASHIZUME, Maurício. Escravidão é flagrada em oficina de costura ligada à Marisa. In: Repórter Brasil, 2010. Disponível em <http://reporterbrasil.org.br/2010/03/escravidao-e-flagradaem-oficina-de-costura-ligada-a-marisa/> . Acesso em 19 out. 2017. 
janelas e portas. "São suprimidos, dessa forma, direitos fundamentais à privacidade e à intimidade dos trabalhadores, os quais se submetem a essas condições para garantir a própria subsistência e a de suas famílias", diz o relatório de fiscalização.

Em um dos espaços, um fogão e um botijão de gás funciona ao lado de um vaso sanitário. Os vários botijões instalados no prédio, aliás, representam risco de explosão, pois estão acomodados em locais fechados e com pouca ventilação. O lixo não é condicionado em recipientes com tampa, causando mau cheiro e atraindo insetos. Os banheiros são coletivos e se encontram em más condições de higiene. $E$ as paredes apresentam grande quantidade de mofo e infiltracões.

Os alimentos são armazenados de forma precária: no chão ou sobre móveis, sem vedação, e, inclusive, no interior de dormitórios. Foram encontrados também produtos vencidos ou à temperatura ambiente quando deveriam ser refrigerados. Para piorar, estavam expostos à contaminação, por conta da grande quantidade de baratas existentes, inclusive, dentro de geladeiras. Os integrantes da fiscalização apontaram, ainda, que a alimentação era muito pobre em nutrientes: eram fornecidos apenas arroz, feijão, salsicha e verduras. Em depoimentos, muitos trabalhadores reclamaram da qualidade da comida oferecida.

$\mathrm{Na}$ visita à oficina, também acompanhada pela reportagem, a fiscalização constatou a falta de aterramento elétrico das máquinas de costura, instalacões elétricas improvisadas, causando riscos de incêndio, e iluminação precária nos banheiros. Além disso, não havia proteção das partes móveis das máquinas; os trabalhadores costuravam próximos de polias e correias, correndo o risco de amputação de membros. ${ }^{32}$ (grifos nossos)

\section{Outra verejista têxtil que reduziu seus empregados à condição} análoga à escrava foi a empresa $\mathrm{C} \& \mathrm{~A}$, que regulava o horário de trabalho de forma abusiva, desrespeitando a folga em feriados, os intervalos, os limites de prorrogação de jornada, dentre outras normas trabalhistas, configurando-se a escravidão por meio da jornada exaustiva, de acordo com o adiante relatado:

Entre outras irregularidades, a C\&A obrigava o trabalho em feriados sem autorização em convenção coletiva, não homologava rescisões no sindicato dos trabalhadores, não concedia intervalo de 15 minutos quando a duração do trabalho ultrapassava quatro horas, impedia o intervalo para repouso e alimentação em situações diversas, prorrogava a jornada de trabalho além do limite legal de duas horas diárias e não pagava horas extras no mês seguinte à

\footnotetext{
32 OJEDA, Igor. Fiscalização flagra exploração de trabalho escravo na confecção de roupas da Renner. In: Repórter Brasil. $2014 . \quad$ Disponível em: $<$ http://reporterbrasil.org.br/2014/11/fiscalizacao-flagra-exploracao-de-trabalho-escravo-naconfeccao-de-roupas-da-renner/>. Acesso em 20 out. 2017.
} 
prestação de serviços. $^{33}$

Registra-se, por oportuno, que os modos de superexploração mencionados nesta seção raramente ocorrem de forma isolada, de modo que o trabalho forçado, a retenção de documentos, a vigilância ostensiva e a negativa de acesso ao transporte casa-trabalho costumam deflagrarem-se em caráter simultâneo aos demais modos de trabalho escravo apresentados. Em outras palavras, é possível dizer que não raro há a constatação de diversos modos de execução de trabalho escravo em um mesmo flagrante.

${ }^{33}$ Tribunal Superior do Trabalho. Rede de lojas é condenada em dano moral coletivo por exigir jornada excessiva. 2014. Disponível em $<\mathrm{http} / /$ www.tst.jus.br/noticias//asset_publisher/89Dk/content/id/9153643>. Acesso em 20 out. 2017. 


\section{PARTE III - O TRÁFICO DE IMIGRANTES LATINO- AMERICANOS PARA A SUSTENTAÇÃO DO SETOR TÊXTIL}

Em 2015, o número de imigrantes que entraram e foram registrados pela Polícia Federal no território brasileiro ultrapassou a soma de 100 mil, sendo destes, mais de 36 mil latino-americanos. ${ }^{34}$

O Brasil e a Agentina costumam ser os pólos receptores de imigrantes mais pobres - em especial os bolivianos - devido ao menor custo de transporte em comparação ao custo para países centrais do continente, além da extensa fronteira que separa a Bolívia destes dois países. ${ }^{35}$

Contudo, como a Argentina tem passado por sequenciais crises econômicas e sociais desde a década de 90, o fluxo de imigrantes passou a ser mais intenso para o Brasil ${ }^{36}$, que veio ao longo dos anos apresentando visibilidade como nação em crescente desenvolvimento - na condição de país emergente - o que gerou expectativas em âmbito continental quanto à possibilidade de se encontrar um mercado de trabalho que proporcionasse melhores condições de vida ao estrangeiro.

Em caráter complementar, vale a menção de que também houve o aumento da imigração para o país a partir da implementação da Lei de Anistia de 1988, que pretendia regular os trabalhadores estrangeiros

\footnotetext{
34 VELASCO, Clara; MANTOVANI, Flávia. Em 10 anos, número de imigrantes aumenta 160\% no Brasil, diz PF. In: G1. 25/06/2016. Disponível em: $<$ http://g1.globo.com/mundo/noticia/2016/06/em-10-anos-numero-de-imigrantes-aumenta-160-nobrasil-diz-pf.html>. Acesso em 16 out. 2017.

${ }^{35}$ CACCIAMALI, Maria Cristina; AZEVEDO, Flávio Antônio de. Entre o tráfico humano e a opção da mobilidade social: A situação dos imigrantes bolivianos na cidade de São Paulo. In: Seminário Internacional Trabalho Escravo por Dívida e Direitos Humanos. Painel: A produção Científica em Construção - Estudos sobre Conflitos no Campo e Trabalho Escravo. 10/11/2005. Disponível em: < http://www.gptec.cfch.ufrj.br/pdfs/trafhumano.pdf>. Acesso em 02 nov. 2017.

${ }^{36}$ CACCIAMALI, Maria Cristina; AZEVEDO, Flávio Antônio de. Entre o tráfico humano e a opção da mobilidade social: A situação dos imigrantes bolivianos na cidade de São Paulo. In: Seminário Internacional Trabalho Escravo por Dívida e Direitos Humanos. Painel: A produção Científica em Construção - Estudos sobre Conflitos no Campo e Trabalho Escravo. 10/11/2005. Disponível em: < http://www.gptec.cfch.ufrj.br/pdfs/trafhumano.pdf>. Acesso em 02 nov. 2017.
} 
indocumentados. $^{37}$

Este fenômeno intenso de imigração dos trabalhadores latinoamericanos para o Brasil em busca de oportunidades de trabalho é melhor explicitado pelo MPT na presente passagem:

Os imigrantes flagrados em São Paulo, por sua vez, vieram para o Brasil coagidos pela pobreza reinante em seus países, Paraguai e Bolívia, assim como os imigrantes da África, Europa Central e Oriental, Ásia e América Latina buscam na Europa mais rica oportunidades de trabalho e sobrevivência que não encontram nos países de origem, colocando-se em situação mais vulnerável ainda, em consequência da clandestinidade. ${ }^{38}$

Ocorre que um dos setores urbanos que proporcionou a maior abertura ao imigrante para o trabalho foi o de corte e costura, que se aproveitou da hipervulnerabilidade decorrente da situação irregular no país, da barreira linguística e da miséria deste tipo específico de trabalhador para a utilização de sua mão de obra de maneira desregulada, sem observância à legislação trabalhista nacional.

A captação de imigrantes para o trabalho na indústria têxtil passou a ocorrer então sob a forma de aliciamento por prepostos do tomador de serviços, responsáveis pelo transporte irregular dos trabalhadores até o local de prestação do labor. Tal prática pode ser esclarecida a partir dos trechos a seguir:

Em quase dois anos de intensas investigações, pudemos verificar que tudo começa com anúncios veiculados em rádios da Bolívia, "seduzindo" as pessoas a trabalhar na cidade de São Paulo com todos os gastos pagos (transporte, casa e comida) e promessas de grandes salários e vida digna. Esses imigrantes viajam milhares de quilômetros e entram no Brasil, pela cidade

\footnotetext{
${ }^{37}$ MERÇON, Marineis. Imigrantes bolivianos no trabalho escravo contemporâneo: análise do caso Zara a partir das RPGs. In: Revista do CEDS. Periódico do Centro de Estudos em Desenvolvimento Sustentável da UNDB. N. 2 - Vol. 1 - março/julho 2015 - Semestral. Disponível em:

$<$ http://www.undb.edu.br/publicacoes/arquivos/revceds_n_2_imigrantes_bolivianos_e_trabalho_es cravo_contemporaneo_caso_zara_marineis_mercon.pdf $>$. Acesso em 23 out. 2017.

${ }^{38}$ SOARES, Evanna. Meios coadjuvantes de combate ao trabalho escravo pelo Ministério Público do Trabalho. Revista do Ministério Público do Trabalho, Brasília, ano XIII, n . 26. São Paulo: Ltr, 2003. p. 34-46. Disponível em:

$<$ http://www.anpt.org.br/attachments/article/2720/Revista\%20MPT\%20-

$\% 20$ Edi\%C3\%A7\%C3\%A3o\%2026.pdf>. Acesso em 04 fev. 2017. p. 37.
} 
de Corumbá, sem passaporte ou apenas com visto de turista. ${ }^{39}$ (grifo nosso)

Quando chegam a São Paulo, são distribuídos entre as oficinas de costuras espalhadas por diversos bairros da cidade de São Paulo, tais como: Bom Retiro, Pari, Moóca e Brás. Ali moram e trabalham, sem descanso, sem nenhum direito trabalhista, em ambiente perigoso e insalubre, pois sempre encontramos lugares sem ventilação, com fiação exposta e tecidos espalhados pelo chão. Na maioria das vezes percebemos fortes indícios de trabalho escravo, porém os trabalhadores nada dizem com receio de represália e de possível expulsão, já que afirmam viverem em melhores condições no Brasil do que em seu país. ${ }^{40}$ (grifos nossos)

Evidentemente, a conduta em comento exibe contornos de tráfico de pessoas - mesmo que o obreiro não seja inicialmente ludibriado - tendo em vista que, quando os trabalhadores chegam ao Brasil, são coagidos a trabalhar em condições subumanas para, inicialmente, saldarem suas dívidas de deslocamento, alimentação e alojamento.

Posteriormente, estes mesmos trabalhadores são coagidos de diversas outras formas, como por meio da retenção de documentos e ameaças de denúncias às autoridades competentes que os levem à deportação, para permanecerem inertes aos abusos diante de sua situação irregular, estando sujeitos às condições mais aviltantes de exploração do trabalho escravo moderno.

Para uma compreensão mais satisfatória sobre o tema, convém nos atentarmos à seguinte definição acerca do conceito de tráfico humano:

A simples facilitação de entrada ilegal, em qualquer território, não pode ser diretamente associada ao tráfico humano. $\mathrm{O}$ tráfico humano é caracterizado por pessoas que ultrapassam fronteiras e logo após, mediante coerção, fraude ou força, estarão sujeitas a um tipo de exploração ou de abuso. Indiferentemente de como a pessoa adentra no país de destino, se por meios legais ou não, existe por

\footnotetext{
39 MENDES, Almara Nogueira. Nova forma de escravidão urbana: Trabalho de imigrantes. Revista do Ministério Público do Trabalho, Brasília, ano XIII, n ${ }^{\circ}$ 26. São Paulo: Ltr, 2003. p. 6770. Disponível em: <http://www.anpt.org.br/attachments/article/2720/Revista\%20MPT\%20\%20Edi\%C3\%A7\%C3\%A3o\%2026.pdf>. Acesso em 04 fev. 2017. p. 68.

40 MENDES, Almara Nogueira. Nova forma de escravidão urbana: Trabalho de imigrantes. Revista do Ministério Público do Trabalho, Brasília, ano XIII, nº 26. São Paulo: Ltr, 2003. p. 6770. Disponível em: <http://www.anpt.org.br/attachments/article/2720/Revista\%20MPT\%20\%20Edi\%C3\%A7\%C3\%A3o\%2026.pdf>. Acesso em 04 fev. 2017. p. 68.
} 
parte de outrem uma intenção prévia de exploração ou de abuso. ${ }^{41}$ (grifo nosso)

O supracitado esclarecimento encontra respaldo no Protocolo de Palermo, ratificado pelo Brasil junto à ONU em janeiro de 2004 e internalizado em março do mesmo ano, com o Decreto $\mathrm{n}^{\circ}$. 5.017, sendo relevante a menção das alíneas a e $\underline{b}$, de seu art. $3^{\circ}$, que trazem a definição de tráfico de pessoas e sua correlação direta com o trabalho forçado:

Artigo 3 - Definições

Para efeitos do presente Protocolo:

a) A expressão "tráfico de pessoas" significa o recrutamento, o transporte, a transferência, o alojamento ou o acolhimento de pessoas, recorrendo à ameaça ou uso da força ou a outras formas de coação, ao rapto, à fraude, ao engano, ao abuso de autoridade ou à situacão de vulnerabilidade ou à entrega ou aceitação de pagamentos ou benefícios para obter o consentimento de uma pessoa que tenha autoridade sobre outra para fins de exploração. A exploração incluirá, no mínimo, a exploração da prostituição de outrem ou outras formas de exploração sexual, o trabalho ou servicos forcados, escravatura ou práticas similares à escravatura, a servidão ou a remoção de órgãos; (grifos nossos)

b) O consentimento dado pela vítima de tráfico de pessoas tendo em vista qualquer tipo de exploração descrito na alínea a) do presente Artigo será considerado irrelevante se tiver sido utilizado qualquer um dos meios referidos na alínea a); (...) (grifos nossos)

$\mathrm{Na}$ oportunidade, cumpre registrar que o entendimento previsto no revogado art. 231 do $\mathrm{CP}$, que caracterizava como tráfico de pessoas somente os casos em que fosse constatado o aliciamento para finalidade exclusiva do exercício da prostituição pela pessoa traficada, foi finalmente superado com o advento da Lei $\mathrm{n}^{\circ} 13.344 / 2016$, estando, atualmente, o Brasil em sintonia com a legislação internacional, sendo agora abarcado no conceito de tráfico humano a submissão de pessoas a qualquer modalidade de trabalho em condições análogas a de escravo mediante aliciamento, conforme o prescrito pelo art. 149-A do nosso diploma criminal:

${ }^{41}$ CACCIAMALI, Maria Cristina; AZEVEDO, Flávio Antônio de. Entre o tráfico humano e a opção da mobilidade social: A situação dos imigrantes bolivianos na cidade de São Paulo. In: Seminário Internacional Trabalho Escravo por Dívida e Direitos Humanos. Painel: A produção Científica em Construção - Estudos sobre Conflitos no Campo e Trabalho Escravo. 10/11/2005. Disponível em: < http://www.gptec.cfch.ufrj.br/pdfs/trafhumano.pdf>. Acesso em 02 nov. 2017. p. 2. 


\section{Tráfico de Pessoas}

Art. 149-A. Agenciar, aliciar, recrutar, transportar, transferir, comprar, alojar ou acolher pessoa, mediante grave ameaça, violência, coação, fraude ou abuso, com a finalidade de:

I - remover-lhe órgãos, tecidos ou partes do corpo;

II - submetê-la a trabalho em condições análogas à de escravo;

III - submetê-la a qualquer tipo de servidão;

IV - adoção ilegal; ou

V - exploração sexual.

Pena - reclusão, de 4 (quatro) a 8 (oito) anos, e multa.

$\S 1$ o A pena é aumentada de um terço até a metade se:

I - o crime for cometido por funcionário público no exercício de suas funções ou a pretexto de exercê-las;

II - o crime for cometido contra criança, adolescente ou pessoa idosa ou com deficiência;

III - o agente se prevalecer de relações de parentesco, domésticas, de coabitação, de hospitalidade, de dependência econômica, de autoridade ou de superioridade hierárquica inerente ao exercício de emprego, cargo ou função; ou IV - a vítima do tráfico de pessoas for retirada do território nacional.

§ 20 A pena é reduzida de um a dois terços se o agente for primário e não integrar organização criminosa.

Ainda, no que se refere à legislação brasileira, cumpre citar a nova Lei de Imigração - Lei $\mathrm{n}^{\circ} 13.445 / 2017$ - que foi sancionada em substituição ao Estatuto do Estrangeiro e tem como objetivo, além de regulamentar a entrada e permanência do estrangeiro no país, facilitar os procedimentos burocráticos de regularização migratória, institucionalizando o procedimento para a concessão de visto humanitário, acabando com a prisão por situação irregular e dando fim a algumas restrições, como a de livre associação sindical. ${ }^{42}$

Não obstante todo o arcabouço normativo que condena o tráfico humano e protege o estrangeiro, o imigrante traficado chega ao país de destino e se depara com a figura da oficina clandestina, onde não somente é sujeito à escravidão por dívida originária do seu próprio aliciamento e à escravidão por retenção de documentos, como também, passa a enfrentar jornadas que o consomem, exaurindo o trabalhador por completo, e

42 REPÓRTER BRASIL. Migração: O Brasil em Movimento / Natália Suzuki (org.); Equipe 'Escravo, nem pensar'. - São Paulo, 2017. Disponível em: <http://escravonempensar.org.br/wpcontent/uploads/2017/10/caderno-migrac\%CC\%A7a\%CC\%83o-22_08_17-baixa.pdf $>$. Acesso em 02 set. 2017. 
condições degradantes de alojamento e trabalho.

Trata-se de clandestina por apresentar a finalidade de servir como "reduto" de superexploração de mão de obra imigrante e comumente estar camuflada como uma simples casa de vizinhança, que sempre está de janelas fechadas e tem o ruído das máquinas abafado pelo som do rádio ligado. ${ }^{43}$

Sua "razão de existir", por assim dizer, é precipuamente esconder dos "olhos" da sociedade crítica e consciente o modo como são confeccionadas as roupas vendidas pelas grandes grifes.

Por este motivo, inclusive, as oficinas que se utilizam de mão de obra escrava frequentemente figuram como "terceirizadas" das grandes marcas de roupa ao mesmo tempo em que produzem parte significativa de sua mercadoria, objetivando-se camuflar os meios escusos de fabricação e afastar qualquer responsabilidade pela ocorrência de trabalho análogo ao escravo no interior da cadeia produtiva da Indústria da Moda.

43 MENDES, Almara Nogueira. Nova forma de escravidão urbana: Trabalho de imigrantes. Revista do Ministério Público do Trabalho, Brasília, ano XIII, n . 26. São Paulo: Ltr, 2003. p. 6770. Disponível em: <http://www.anpt.org.br/attachments/article/2720/Revista\%20MPT\%20\%20Edi\%C3\%A7\%C3\%A3o\%2026.pdf>. Acesso em 04 fev. 2017. 


\section{PARTE IV - A CONFIGURAÇÃO DA RESPONSABILIDADE DAS MAGAZINES ANTE O TRABALHO ESCRAVO IDENTIFICADO NA SUA CADEIA PRODUTIVA}

\section{A Teoria da Subordinação Estrutural}

Considerando, preliminarmente, que o art. $3^{\circ}$ da CLT reconhece a existência de vínculo empregatício quando presentes a pessoalidade e a subordinação jurídica, é possível se constatar, a contrário senso, que na terceirização lícita somente haverá pessoalidade e subordinação do terceirizado perante a empresa interposta, sendo esta a empregadora da relação jurídica de fato.

Sucede que, frequentemente, vislumbra-se nas oficinas clandestinas - facções - de corte e costura que participam da cadeia de terceirização de multinacionais fortes indícios do exercício de poder diretivo, hierárquico e disciplinar - intrínsecos ao conceito de subordinação - destas últimas sob seus terceirizados a partir do atendimento compulsório ao modelo de negócios da empresa tomadora, estando claro o mero fornecimento de mão de obra com o intuito do real empregador se isentar dos riscos do negócio, bem como, do pagamento de direitos trabalhistas e previdenciários.

O mencionado modelo de negócios tende a ser introduzido nas oficinas de costura por meio de um "Manual de Fornecimento"44, que serve como instrumento velado para uso do poder diretivo pelas magazines e, dessa forma, estabelece uma série de parâmetros a serem rigorasamente cumpridos, como: a definição de peças, desenho de roupas, qualidade, preço, cores, medidas, modelo, material a ser utilizado, quantidade a ser produzida, prazo para entrega, especificação de adornos e etiquetas, e, inclusive, a imposição de penalidades diante do não cumprimento de tais exigências, como, por exemplo, a aplicação de multa aos trabalhadores e o

\footnotetext{
${ }^{44}$ BRASIL. Ministério Público do Trabalho. Procuradoria Regional do Trabalho da $2^{\mathrm{a}}$ Região. Ação Civil Pública. Réu: M5 Indústria e Comércio Ltda. 2014. Disponível em: $<$ http://reporterbrasil.org.br/documentos/acp-mofficer.pdf $>$. Acesso em 14 jul. 2017
} 
descredenciamento.

As diretrizes acima elencadas demonstram uma efetiva subordinação entre o tomador de serviços (real empregador) e aqueles que fornecem sua mão de obra sob o título de terceirização.

Permitindo uma melhor visualização da subordinação em referência, podemos trazer ao estudo a Teoria da Subordinação Estrutural ou Integrativa $^{45}$, formulada pelo Professor Maurício Godinho, que busca caracterizar como empregado todo o trabalhador inserido no contexto macro de ambiente de trabalho que esteja, indireta ou diretamente, sob a gestão do tomador de serviços, sendo a integração do trabalhador à dinâmica organizativa e operacional do tomador com sua consequente incorporação e submissão à cultura corporativa da empresa elemento essencial do instituto. ${ }^{46}$

O conceito da subordinação estrutural nasce diante dos novos sistemas de produção do século XXI, em especial, as dinâmicas mercadológicas voltadas para a acumulação flexível (Modelo do Toyotismo), que passaram a permitir a gestão indireta do empregador sobre seus funcionários, concentrando-se este em apenas ordenar a produção como um todo.

Diante das recentes tendências trazidas pela complexidade da sociedade globalizada que ampliaram as formas de subcontratação de trabalhadores, a exemplo dos casos de cooperativas e terceirizações, necessário se faz a adoção de institutos que estabeleçam a manutenção do Princípio Protetivo do Trabalhador a fim de que contratações fraudulentas sejam evitadas. ${ }^{47}$

45 BRASIL. Ministério Público do Trabalho. Procuradoria Regional do Trabalho da 2a Região. Ação Civil Pública. Réu: M5 Indústria e Comércio Ltda. 2014. Disponível em: $<$ http://reporterbrasil.org.br/documentos/acp-mofficer.pdf>. Acesso em 14 jul. 2017

${ }^{46}$ DELGADO. Maurício Godinho. Curso de Direito do Trabalho. 15 a ed. São Paulo: LTr, 2016.

${ }^{47}$ DELGADO. Maurício Godinho. Curso de Direito do Trabalho. $15^{\mathrm{a}}$ ed. São Paulo: LTr, 2016. 
Nesse liame, podemos dizer que a Teoria da Subordinação Estrutural vem para abraçar as novas relações de emprego que a subordinação clássica não mais consegue englobar, sendo fundamental sua aplicação em casos que buscam desvirtuar a terceirização/quarteirização.

Vale ressaltar que no contexto da Subordinação Estrutural, a empresa que se apresenta como tomadora de serviços - antes tida responsável subsidiária - passa a atuar na figura de devedora principal, quando verificado que o trabalhador terceirizado é essencial para a estrutura da atividade desenvolvida, a ponto de ser constatada uma total dependência recíproca entre empregado e empregador. ${ }^{48}$

Nesse sentido, seguem acertadas jurisprudências de nossos Tribunais Regionais do Trabalho sobre o tema, demonstrando-se a plena aplicação do instituto:

VÍNCULO DE EMPREGO. SUBORDINAÇÃO ESTRUTURAL. Há subordinacão estrutural quando o trabalhador se insere na organizacão empresarial, de forma não eventual, pessoal e onerosa, prestando serviços essenciais e ligados ao objeto da reclamada, integrando-se, portanto, no empreendimento. Estando presentes todos os elementos a tanto, é reconhecido o vínculo de emprego entre as partes.

(TRT-4 - RO: 00204257220145040373, Data de Julgamento: 05/05/2017, $7^{\mathrm{a}}$ Turma) - (grifos nossos)

VÍNCULO DE EMPREGO. SUBORDINAÇÃO ESTRUTURAL. $\underline{\mathbf{O} \text { autor }}$ executava servicos ligados diretamente ao objeto social da reclamada, de modo habitual e rotineiro, caracterizando-se, assim, a subordinação estrutural. Havia, ainda, a presença dos demais elementos previstos nos artigos $2^{\circ}$ e $3^{\circ}$ da CLT. Deve-se reconhecer, portanto, o vínculo de emprego entre as partes.

(TRT-1 - RO: 01008301320165010049, Relator: JOSÉ LUIS CAMPOS XAVIER, Data de Julgamento: 10/05/2017, Sétima Turma, Data de Publicação: 05/06/2017) - (grifos nossos)

EMPRESA DE CONSTRUÇÃO E COMERCIALIZAÇÃO DE IMÓVEIS. INSERÇÃO DO TRABALHADOR CORRETOR/VENDEDOR NOS OBJETIVOS DO EMPREENDIMENTO. PRESENÇA DE SUBORDINAÇÃO

${ }^{48}$ FRAGA, Cristiano. Subordinação Estrutural: Um novo paradigma para as relações de emprego. Disponível em:

$<$ http://www3.pucrs.br/pucrs/files/uni/poa/direito/graduacao/tcc/tcc2/trabalhos2011_1/cristiano_fr aga.pdf $>$. Acesso em 20 ago. 2017. 
ESTRUTURAL. VÍNCULO DE EMPREGO RECONHECIDO - Se a trabalhadora se encontrava inteiramente inserida nos objetivos econômicos e sociais da empresa de construção e venda de imóveis, que coordenava o labor e dele auferia os frutos, evidenciada a sujeição ao poder diretivo empresarial, independentemente da qualificação que possa ter sido atribuída ao contrato. Relação de emprego reconhecida. Recurso improvido neste tópico.

(TRT-24 00242567920155240004, Relator: FRANCISCO DAS CHAGAS LIMA FILHO, 2 ${ }^{\text {a }}$ TURMA, Data de Publicação: 09/08/2017) - (grifos nossos)

No âmbito da indústria da moda e sua rede de subcontratações, "A tese da subordinação jurídico estrutural defende que a proteção ao trabalhador seja feita a partir da chamada subordinação objetiva, ou seja, pelo reconhecimento de que sua atividade é controlada pela grife, ainda que seu contrato de trabalho seja com a oficina de costura"49.

Assim sendo, estando evidente o elevado nível de dependência das grandes empresas do mercado fast fashion para com seus "terceirizados" e, consequentemente, sendo perceptível que tais empregados constituem parte essencial da sua cadeia produtiva - com a frequente ocorrência de exclusividade na prestação de serviços entre as oficinas e as grifes -, é facilmente afastável a autonomia pretendida em uma relação meramente comercial de compra e venda de mercadorias.

Por esse e os demais motivos apresentados, é plenamente possível dizer que os empregados subcontratados que estão inseridos dentro da estrutura essencial de uma empresa através de uma lógica de fracionamento organizacional, recebendo ordens claras sobre como agir e como produzir, verificando-se, aliás, uma interdependência total entre o "terceirizado" e o tomador de serviços, se encontram verdadeiramente subordinados à magazine, que deverá responder diretamente por qualquer violação trabalhista a eles perpetrada, inclusive, aquela que configura o trabalho análogo ao escravo.

49 BRIANEZI, Thaís. Para procuradores, terceirização não anula culpa por trabalho escravo. In: Repórter Brasil. 14/11/2014. Disponível em <http://reporterbrasil.org.br/2014/11/procuradoresdefendem-responsabilizacao-civil-trabalhista-e-criminal-dos-elos-finais-das-cadeias-produtivasflagradas-com-trabalho-escravo/>. Acesso em 23 set. 2017. 


\section{A Responsabilidade em Cadeia}

Caso seja ultrapassada a possibilidade de se reconhecer a grife como real empregadora dos trabalhadores subcontratados que laboram em oficinas clandestinas, passamos aqui a defender a responsabilidade ao menos solidária do empresário que claramente se utiliza da intermediação de mão de obra para explorar a miséria e a hipervulnerabilidade dos imigrantes que buscam no mercado têxtil uma oportunidade de melhorar de vida.

Por meio da intermediação de mão de obra, muitas empresas do ramo fast fashion formadoras de cadeia produtiva acabam esquivando-se de encargos trabalhistas, subcontratando empresas menores que mantém seus trabalhadores laborando em condições de superexploração.

O trecho a seguir transcrito deixa bem nítida a intermediação de mão de obra revestida de terceirização com o simples objetivo de resguardar a empresa "dona da cadeia" de eventuais condenações trabalhistas, vez que, não raro, o trabalho das oficinas clandestinas é completamente absorvido por uma só magazine:

Essas oficinas informais muitas vezes têm apenas uma empresa como cliente e produzem roupas exclusivamente para uma marca. Elas frequentemente são criadas por ex-funcionários da empresa cliente para cumprir as demandas de costura anteriormente atendidas pela força de trabalho própria da cliente. A fragilidade econômica dessas oficinas é um grande problema para os empregados. Muitas delas fecham logo após o início das atividades, não pagam verbas rescisórias e não emitem os documentos necessários para que seus empregados recebam o seguro-desemprego. ${ }^{50}$ (grifos nossos)

É necessário ressaltar, em observância ao que fora citado, que por se tratarem de meio estratégico para pulverizar a produção e camuflar uma

\footnotetext{
${ }^{50}$ CAMPOS, André (Repórter Brasil); HUIJSTEE, Mariëtte van; THEUWS, Martje (SOMO). $D a$ responsabilidade moral à responsabilização jurídica? As condições de escravidão moderna na cadeia global de suprimentos da indústria do vestuário e a necessidade de fortalecer os marcos regulatórios: o caso da Inditex-Zara no Brasil. Amsterdã, mai. 2015. Disponível em $<$ http://reporterbrasil.org.br/wp-content/uploads/2015/05/Reporter-Brasil-web-P.pdf $>$. Acesso em 20 set. 2017.
} 
intermediação de mão de obra, as oficinas clandestinas pouco possuem de caixa para arcar com suas condenações trabalhistas, sendo mais que necessário que a grife atue solidariamente no polo passivo para que os trabalhadores superexplorados possam, ao menos, reaver as verbas que fazem jus.

Certo é que aquele que possui o poder econômico determinante dentro de uma cadeia produtiva - a grande varejista - é o que mais se beneficia com o trabalho humano nela desempenhado, devendo minimamente arcar o ônus resultante das suas operações, onde se encaixaria a sua atuação como responsável solidário pelos danos perpetrados aos trabalhadores.

Nesse mesmo sentido, temos que:

É incontestável que o pequeno agenciador - o "gato", nas atividades rurais; o oficinista, na indústria têxtil ou o arregimentador de turmas, na construção civil - não é o principal obtentor de lucro no contexto da submissão de trabalhadores à condição análoga à de escravo. Por consequência, não deve ser o único a responder pelo fato, seja com a imposição de obrigações de fazer ou não fazer e/ou pagamento de indenizações, no caso do plano civil-trabalhista, seja com a pena criminal. Para além dessa primeira camada, há um encadeamento de exploração nesses modelos produtivos que envolve pecuaristas e frigoríficos, carvoeiros e siderúrgicas, confecções e grifes, construtoras terceirizadas e grandes empreiteiras. Então, sob pena de reprodução das estruturas excludentes e desiguais da nossa sociedade, punir apenas a camada mais imediata não é suficiente sequer para questionar o sistema laboral que reduz trabalhadores à situação de escravos. Necessário chegar aos maiores beneficiados e aos que auferem grandes lucros a partir dessa estrutura perversa. ${ }^{51}$ (grifo nosso)

Em entendimento complementar, seguem as jurisprudências adiante expostas:

DIREITOS TRABALHISTAS. Hipótese em que verificada a intermediação de mão de obra, mediante a prestação de trabalho da reclamante na cadeia de produção das empresas tomadoras, situação que importa em inequívoca

51 SEGATTI, Ana Elisa Alves Brito; NOVAES, Dirce Trevisi Prado; NOGUEIRA, Christiane Vieira; SABINO, João Filipe Moreira Lacerda; FORTES, Mariana Flesch. Trabalho Escravo: Reflexões sobre a Responsabilidade na Cadeia Produtiva. Revista do Ministério Público do Trabalho, Brasília, ano XXIV, $\mathrm{n}^{\circ}$. 48. São Paulo: Ltr, 2015. p. 68. Disponível em: < http://www.tridiacriacao.com/clientes/anpt/images/olds/arquivos/revista-MPT-48_anpt23121.pdf >. Acesso em 04 out.. 2017. 
fraude aos direitos trabalhistas, incidindo, na espécie, o disposto no art. $9^{\circ}$ da CLT. Responsabilidade solidária reconhecida. Recurso ordinário provido, no aspecto.

(TRT- 4 - RO: 00011877520115040372 RS 0001187-75.2011.5.04.0372, RELATOR: LAÍS HELENA JAEGER NICOTTI, Data de Julgamento: 16/07/2014, $2^{\text {a }}$ Vara do Trabalho de Sapiranga) - (grifos nossos)

AGRAVO DE INSTRUMENTO. RECURSO DE REVISTA INTERPOSTO NA VIGÊNCIA DA LEI $\mathrm{N}^{\circ} \quad 13.015 / 2014$. TERCEIRIZAÇÃO ILÍCITA. RESPONSABILIDADE SOLIDÁRIA. CONDIÇÕES ANÁLOGAS ÀS DE ESCRAVO 1. Ao contratar empresa inidônea, que mantém empregados em condicões de trabalho análogas às de escravo mediante pacto no qual a reducão de custos figura como objetivo a ser atingido, a tomadora de servicos torna-se coautora do ilícito cometido por aquela. 2. Tais circunstâncias atraem sua responsabilidade solidária pelos prejuízos causados, à luz do art. 942 do Código Civil. 3. Agravo de instrumento da Reclamada de que se conhece e a que se nega provimento.

(TST - AIRR: 13452020105020050, Relator: João Oreste Dalazen, Data de Julgamento: 24/05/2017, 4a Turma, Data de Publicação: DEJT 09/06/2017) (grifos nossos)

Registra-se que, no âmbito da responsabilidade solidária, os agentes que concorrem no dano são simultaneamente responsabilizados, devendo o trabalhador poder exigir seu crédito de todos os corresponsáveis pelo adimplemento da obrigação, inclusive das magazines, não tendo de ficar à mercê das facções para a garantia de seu direito.

Como tal responsabilidade não se presume, podemos recorrer a uma leitura integrada do parágrafo único, do art. $8^{\circ}$ da CLT, que permite o uso subsidiário de normas do direito comum que forem compatíveis com os princípios do direito do trabalho, com o art. 942 do $\mathrm{CC}$, que autoriza a responsabilização solidária de todos os responsáveis pela produção de um dano. $^{52}$

Ademais, é possível também aplicarmos, por analogia e com a permissão do já citado art. $8^{\circ}$ da CLT, a lógica protetiva do CDC responsável por atribuir a todos os integrantes de certa cadeia produtiva,

52 NAGAHIRO, Vanessa Cristina Parra; MELLER, Fernanda. Responsabilização das empresas nas cadeias produtivas frente ao trabalho escravo contemporâneo. In: Âmbito Jurídico, Rio Grande, XIX, n. 144, jan 2016. Disponível em: <http://www.ambitojuridico.com.br/site/?n_link=revista_artigos_leitura\&artigo_id=16700>. Acesso em 12 out. 2017. 
desde o fabricante até o importador, a responsabilidade objetiva e solidária pelos danos causados por produtos/serviços defeituosos, vez que os trabalhadores desta cadeia igualmente figuram ao lado do consumidor final como personas vulneráveis, sendo perfeitamente razoável que estejam amparados pelo mesmo fundamento. ${ }^{53}$

Por fim, convém destacar que a $103^{\mathrm{a}}$ Conferência Internacional do Trabalho (2014) estabeleceu como primordial o reconhecimento da responsabilidade em cadeia sempre que houver o risco de prestação de serviços e fabricação de produtos por meio do uso de mão de obra escrava. ${ }^{54}$

Diante de todo o exposto, entendendo-se que a responsabilização dos que exploram a mão de obra análoga à escrava deve ser desenvolvida abarcando o contexto de toda a cadeia produtiva e, não somente, a camada mais imediata ao trabalhador, a exemplo dos oficinistas, é impositivo que o ônus seja distribuído a todas as camadas de exploração, em especial, aos beneficiários finais - as grandes varejistas, uma vez que são estes os que verdadeiramente lucram com a lógica instaurada do trabalho escravo.

\footnotetext{
${ }^{53}$ NAGAHIRO, Vanessa Cristina Parra; MELLER, Fernanda. Responsabilização das empresas nas cadeias produtivas frente ao trabalho escravo contemporâneo. In: Ambito Jurídico, Rio Grande, XIX, n. 144, jan 2016. Disponível em: <http://www.ambitojuridico.com.br/site/?n_link=revista_artigos_leitura\&artigo_id=16700>. Acesso em 12 out 2017. 54 BRASIL. Ministério Público do Trabalho. Procuradoria Regional do Trabalho da $2^{\mathrm{a}}$ Região. Ação Civil Pública. Réu: M5 Indústria e Comércio Ltda. 2014. Disponível em: $<$ http://reporterbrasil.org.br/documentos/acp-mofficer.pdf>. Acesso em 14 jul. 2017
} 


\section{A Teoria da Cegueira Deliberada}

Também é possível invocar a Teoria da Cegueira deliberada para chegarmos à responsabilidade das grandes grifes de moda pelo uso de trabalho escravo contemporâneo dentro de sua cadeia produtiva.

Inicialmente, cumpre relembrar que as marcas fast fashion comumente realizam a terceirização do seu serviço de corte e costura a fornecedores que evidentemente não possuem mecanismo produtivo em larga escala, o que torna claro o seu consentimento com a subcontratação de facções, dando ensejo à quarteirização da produção.

Tal pulverização do processo produtivo por meio das subcontratações passa a ser tão somente instrumento de ocultação da precarização do trabalho, dificultando a fiscalização dos órgãos públicos.

Nesse liame, o MPT explica:

Trocando em miúdos, o que ocorre é o seguinte: a Ré pulveriza sua produção, sugando a força de trabalho migrante e precária, barateando os custos, fechando os olhos para o 'problema' social e trabalhista e, mais importante, se isentando de qualquer responsabilidade pelas irregularidades verificadas 'lá por baixo'. ${ }^{55}$ (grifo nosso)

Com o objetivo de enfrentar esta omissão quanto à responsabilidade pelas irregularidades identificadas no processo de manufatura têxtil, trazemos à discussão a Teoria da Cegueira Deliberada.

A Teoria da Cegueira Deliberada, também conhecida como Teoria da Síndrome do Avestruz, tem origem na Suprema Corte Americana e busca imputar a responsabilidade pelo crime derivado àquele que intencionalmente se omite quanto a um dever razoável de impedir a ocorrência do ilícito, ou seja, aquele que conscientemente “(...) comportase como uma avestruz, que enterra sua cabeça na terra para não tomar

\footnotetext{
${ }^{55}$ BRASIL. Ministério Público do Trabalho. Procuradoria Regional do Trabalho da $2^{\mathrm{a}}$ Região. Ação Civil Pública. Réu: M5 Indústria e Comércio Ltda. 2014. Disponível em: $<$ http://reporterbrasil.org.br/documentos/acp-mofficer.pdf $>$. Acesso em 14 jul. 2017. p. 73.
} 
conhecimento da natureza ou extensão do seu ilícito praticado (...)"56, a exemplo do gestor de marca têxtil que não procura saber o que ocorre em sua cadeia produtiva, como se as subcontratações fossem meios suficientes para afastar seu dever de cautela e responsabilidade em cascata. ${ }^{57}$

No geral, as empresas se utilizam dos limites de seu estabelecimento para enfrentar a teoria em comento, ao invés de adotarem medidas que fiscalizem efetivamente as oficinas contratadas por seus fornecedores.

Por conseguinte, nasce a necessidade de se imputar uma responsabilidade objetiva ao beneficiário direto da cadeia têxtil, ante o seu claro poder econômico em interferir na teia produtiva e resguardar aqueles que dela fazem parte, afinal:

É inegável que a tomadora final dos serviços prestados lá embaixo, em condições subumanas, se omitiu no seu dever social, jurídico e cívico de conhecer os métodos materiais e humanos utilizados para a confecção dos produtos que encomenda. Não se preocupou em aferir a real capacidade produtiva daqueles que lhe prestam serviços e não teve interesse, sequer, em verificar como seu produto foi fabricado. Beneficiou-se diretamente da forca de trabalho de toda a cadeia produtiva, mas deliberadamente fechou os olhos para as condicões da produção, pondo-se em condição de ignorância. Trata-se de uma cegueira absolutamente proposital em face daquilo que ocorre ao seu redor. ${ }^{58}$ _(grifo nosso)

Em conformidade com o apresentado, convém aqui também trazer o seguinte trecho de decisão em sede de Recurso Ordinário do Tribunal Regional do Trabalho da $1^{\text {a }}$ Região:

A denominada "Teoria da Cegueira deliberada", também conhecida como "Teoria do Avestruz", deve ser aplicada de modo a impedir que o maior beneficiado pela prestação dos serviços, embora não tenha participado diretamente das práticas ilegais ora constatadas, negue conhecimento ou mesmo responsabilidade sobre as ilicitudes perpetradas pela empresa por ela contratada.

\footnotetext{
${ }^{56}$ CABRAL, Bruno Fontenele. Breves comentários sobre a teoria da cegueira deliberada (willful blindness doctrine). In: Revista Jus Navigandi, ISSN 1518-4862, Teresina, ano 17, n. 3193, 29/03/2012. Disponível em: <https://jus.com.br/artigos/21395>. Acesso em: 24 set. 2017.

57 BRASIL. Ministério Público do Trabalho. Procuradoria Regional do Trabalho da $2^{\mathrm{a}}$ Região. Ação Civil Pública. Réu: M5 Indústria e Comércio Ltda. 2014. Disponível em: $<$ http://reporterbrasil.org.br/documentos/acp-mofficer.pdf >. Acesso em 14 jul. 2017.

${ }^{58}$ CAVALCANTI, Tiago Muniz. Trabalho escravo na moda: os grilhões ocultos da elite brasileira. In: Repórter Brasil. 26/11/2013. Disponível em: <http://reporterbrasil.org.br/2013/11/os-grilhoesocultos-da-elite-brasileira/>. Acesso em 02 out. 2017.
} 
Por óbvio, o tomador dos servicos não poderia fechar os olhos às condicões do meio ambiente laboral dos empregados utilizados em sua cadeia produtiva.

Reconheço, pois, a responsabilidade da segunda ré pelos créditos aqui reconhecidos.

(TRT-1 - RO: 01109003020045010431 RJ, Relator: Evandro Pereira Valadao Lopes, Data de Julgamento: 31/03/2015, Quinta Turma, Data de Publicação: 08/06/2015) - (grifo nosso)

Nesse sentido, resta evidente que o empregador possui o poder-dever de fiscalizar, prevenir e remediar seus fornecedores quanto às práticas adotadas no trato de seus trabalhadores terceirizados, não sendo crível que se utilize de subcontratações sucessivas para afastar qualquer responsabilização quanto aos empregados que compõem sua cadeia produtiva. 


\section{A Teoria dos Contratos Coligados}

Como já anteriormente esclarecido, as cadeias produtivas têm como característica primordial a fragmentação de sua produção através de subcontratações em sequência, de tal modo que a empresa tomadora final dos serviços, a exemplo da grife de moda, permaneça diretamente dependente dos produtos gerados e das atividades realizadas ao longo de sua teia produtiva.

Tal teia produtiva é entrelaçada por meio de uma rede contratual, sendo esta motivada pura e simplesmente pelo desvirtuamento de vínculos trabalhistas, ocultando-se a real vontade da beneficiária final - a magazine de se desobrigar de direitos trabalhistas e afastar a responsabilidade pela superexploração dos trabalhadores que lhes prestam serviços de forma intermediada. ${ }^{59}$

Dessa forma, os contratos que irão "tecer" a rede de subcontratações deverão ser interdependentes, conexos e coligados, pois possuem um nexo funcional comum ao passo que convergem para uma mesma finalidade econômica - a confecção e venda de roupas, não havendo razão de um contrato existir sem os demais, sendo certo que as consequências de determinada obrigação irão repercutir nas demais que integram a cadeia produtiva. $^{60}$

Diante da referente interdependência de obrigações, nos deparamos com a Teoria dos Contratos Coligados, emprestada do Direito Empresarial, capaz de nos fornecer subsídios para a construção de uma responsabilidade solidária entre os contratantes que concorreram para um mesmo dano e não

\footnotetext{
${ }^{59}$ NAGAHIRO, Vanessa Cristina Parra; MELLER, Fernanda. Responsabilização das empresas nas cadeias produtivas frente ao trabalho escravo contemporâneo. In: Ambito Jurídico, Rio Grande, XIX, n. 144, jan 2016. Disponível em: <http://www.ambitojuridico.com.br/site/?n_link=revista_artigos_leitura\&artigo_id=16700>. Acesso em 12 out 2017. ${ }^{60}$ NAGAHIRO, Vanessa Cristina Parra; MELLER, Fernanda. Responsabilização das empresas nas cadeias produtivas frente ao trabalho escravo contemporâneo. In: Ambito Jurídico, Rio Grande, XIX, n. 144, jan 2016. Disponível em: <http://www.ambitojuridico.com.br/site/?n_link=revista_artigos_leitura\&artigo_id=16700>. Acesso em 12 out 2017.
} 
fizeram jus aos princípios da boa fé objetiva e da função social dos contratos, estabelecidos nos arts. 112, 113, 421 e 422 do CC - essenciais à segurança dos negócios jurídicos - devendo ser interpretados em observância aos fundamentos da nossa Carta Cidadã, a qual é clara quanto ao dever da coletividade na valorização do trabalho humano e da Justiça Social, coforme o disposto em seu art. 170 , caput. ${ }^{61}$.

Considerando como imperativa a importância dada ao ser trabalhador, cumpre a nós também aqui aplicarmos o art. $2^{\circ}$ da CLT, que a contrário senso veda a transferência dos riscos da atividade econômica ao obreiro, sendo o desrespeito a este dispositivo motivo suficiente para caracterizar fraude e dano ao trabalhador, devendo-se, desse modo, também ser observado o art. $9^{\circ}$ da CLT, que tem como nulo de pleno direito os atos praticados para desvirtuar os preceitos da ordem trabalhista ${ }^{62}$, "abrindo-se portas" para a cumulativa aplicação da responsabilidade solidária presente na interpretação integrada dos arts. 927, 932, inciso III, 933 e 942, do CC. ${ }^{63}$

Ademais, convém ainda dizer que a Teoria dos Contratos Coligados possui ampla aplicação dentro do direito consumerista, ante a clara hipossuficiência dos consumidores, o que em muito se assemelha à lógica protetiva que deve ser empregada aos trabalhadores, conforme alinhado no capítulo 7 dessa seção, valendo-se do art. $8^{\circ}$, PU, da CLT, como norma autorizativa para a aplicação do direito comum como fonte subsidiária ao

\footnotetext{
${ }^{61}$ SEGATTI, Ana Elisa Alves Brito; NOVAES, Dirce Trevisi Prado; NOGUEIRA, Christiane Vieira; SABINO, João Filipe Moreira Lacerda; FORTES, Mariana Flesch. Trabalho Escravo: Reflexões sobre a responsabilidade na cadeia produtiva. Revista do Ministério Público do Trabalho, Brasília, ano XXIV, $\mathrm{n}^{\circ}$. 48. São Paulo: Ltr, 2015. p. 67-85. Disponível em: < http://www.tridiacriacao.com/clientes/anpt/images/olds/arquivos/revista-MPT-48_anpt23121.pdf >. Acesso em 04 out.. 2017.

62 SEGATTI, Ana Elisa Alves Brito; NOVAES, Dirce Trevisi Prado; NOGUEIRA, Christiane Vieira; SABINO, João Filipe Moreira Lacerda; FORTES, Mariana Flesch. Trabalho Escravo: Reflexões sobre a responsabilidade na cadeia produtiva. Revista do Ministério Público do Trabalho, Brasília, ano XXIV, $\mathrm{n}^{\circ}$. 48. São Paulo: Ltr, 2015. p. 67-85. Disponível em: < http://www.tridiacriacao.com/clientes/anpt/images/olds/arquivos/revista-MPT-48_anpt23121.pdf >. Acesso em 04 out.. 2017.

${ }^{63}$ NAGAHIRO, Vanessa Cristina Parra; MELLER, Fernanda. Responsabilização das empresas nas cadeias produtivas frente ao trabalho escravo contemporâneo. In: Ambito Jurídico, Rio Grande, XIX, n. 144, jan 2016. Disponível em: <http://www.ambitojuridico.com.br/site/?n_link=revista_artigos_leitura\&artigo_id=16700>. Acesso em 12 out 2017.
} 
que não lhe for incompatível.

Em síntese, temos que:

Entre os princípios centrais do direito laboral está o da proteção. Assim, a teoria geral dos contratos trazida pelo novo Código Civil, com ênfase na boa-fé objetiva e na função social dos contratos, a protecão ao hipossuficiente prevista pelo Direito do Consumidor, dos quais decorre a teoria da responsabilização solidária em rede, ao revés, são não apenas compatíveis com os princípios do direito do trabalho, mas absolutamente convergentes. ${ }^{64}$ (grifo nosso)

Isto posto, resta clara a possibilidade de uso da teoria em comento para buscar a responsabilidade em cadeia dos contratantes (magazine confecções - oficinas clandestinas), tendo em vista que todos concorreram para a prática do trabalho análogo ao escravo em busca de um mesmo fim, a maximização do lucro na produção e venda de roupas em detrimento da dignidade humana.

${ }^{64}$ SEGATTI, Ana Elisa Alves Brito; NOVAES, Dirce Trevisi Prado; NOGUEIRA, Christiane Vieira; SABINO, João Filipe Moreira Lacerda; FORTES, Mariana Flesch. Trabalho Escravo: Reflexões sobre a responsabilidade na cadeia produtiva. Revista do Ministério Público do Trabalho, Brasília, ano XXIV, $\mathrm{n}^{\circ}$. 48. São Paulo: Ltr, 2015. p. 76. Disponível em: < http://www.tridiacriacao.com/clientes/anpt/images/olds/arquivos/revista-MPT-48_anpt23121.pdf >. Acesso em 04 out.. 2017. 


\section{A Responsabilidade Ambiental no Contexto do Ambiente de Trabalho Precário}

A proteção ao meio ambiente está consagrada por diversos diplomas do nosso ordenamento jurídico, sendo impositivo que toda a coletividade adote mecanismos de precaução e prevenção na prática de suas ações, a fim de se propiciar o desenvolvimento salutar das gerações futuras.

O direito ao meio ambiente saudável e seguro e, por consequência, ao meio ambiente de trabalho sadio, encontra respaldo constitucional nos seguintes artigos: 65

Art. $6^{\circ}$ São direitos sociais a educação, a saúde, a alimentação, o trabalho, a moradia, o transporte, o lazer, a segurança, a previdência social, a proteção à maternidade e à infância, a assistência aos desamparados, na forma desta Constituição. (grifo nosso)

Art. $7^{\circ}$ São direitos dos trabalhadores urbanos e rurais, além de outros que visem à melhoria de sua condição social:

XXII - redução dos riscos inerentes ao trabalho, por meio de normas de saúde, higiene e seguranca;

XXIII - adicional de remuneração para as atividades penosas, insalubres ou perigosas, na forma da lei; (...) (grifos nossos)

Art. 170. A ordem econômica, fundada na valorizacão do trabalho humano e na livre iniciativa, tem por fim assegurar a todos existência digna, conforme os ditames da justiça social, observados os seguintes princípios:

VI - defesa do meio ambiente, inclusive mediante tratamento diferenciado conforme o impacto ambiental dos produtos e serviços e de seus processos de elaboração e prestação; (grifos nossos)

Art. 196. A saúde é direito de todos e dever do Estado, garantido mediante políticas sociais e econômicas que visem à redução do risco de doença e de outros agravos e ao acesso universal e igualitário às ações e serviços para sua promoção, proteção e recuperação. (grifo nosso)

Art. 200. Ao sistema único de saúde compete, além de outras atribuições, nos termos da lei:

VIII - colaborar na protecão do meio ambiente, nele compreendido o do trabalho. (grifo nosso)

Art. 225. Todos têm direito ao meio ambiente ecologicamente equilibrado, bem de uso comum do povo e essencial à sadia qualidade de vida, impondo-se ao Poder Público e à coletividade o dever de defendê-lo e preservá- lo para as

${ }^{65}$ BRASIL. Ministério Público do Trabalho. Procuradoria Regional do Trabalho da $2^{\mathrm{a}}$ Região. Ação Civil Pública. Réu: M5 Indústria e Comércio Ltda. 2014. Disponível em: $<$ http://reporterbrasil.org.br/documentos/acp-mofficer.pdf $>$. Acesso em 14 jul. 2017 
presentes e futuras gerações.

$\S 3^{\circ}$ As condutas e atividades consideradas lesivas ao meio ambiente sujeitarão os infratores, pessoas físicas ou jurídicas, a sancões penais e administrativas, independentemente da obrigação de reparar os danos causados. (grifos nossos)

Tais normas, apesar de se encontrarem na lei máxima do direito brasileiro, são comumente ignoradas por diversas empresas que fazem parte do mercado fast fashion, estando sua violação, inclusive, elencada como um dos modos de execução do trabalho análogo ao escravo, qual seja, o trabalho em "condições degradantes".

As condições degradantes comumente se verificam nas circunstâncias precárias das instalações sanitárias e elétricas, na ausência de iluminação e refrigeração, na presença recorrente de mofos e infiltrações, na falta de aterramento elétrico das máquinas de costura, na inexistência de extintores de incêndio, na não disposição aos trabalhadores de equipamento de segurança adequado (Equipamento de Proteção Individual - EPI), no não fornecimento de água potável, dentre diversas outras condutas irregulares que põem em risco a vida dos que laboram nas oficinas de corte e costura. 66

Cumpre aqui salientar, que os alojamentos constituem extensão ${ }^{67}$ das facções, de modo que as normas protetivas ao meio ambiente não devem se restringir apenas ao domínio onde estão localizadas as máquinas de trabalho.

Estes alojamentos, não raro, são tidos como ambientes inóspitos, onde encontramos a superlotação de trabalhadores, o armazenamento

\footnotetext{
66 SEGATTI, Ana Elisa Alves Brito; NOVAES, Dirce Trevisi Prado; NOGUEIRA, Christiane Vieira; SABINO, João Filipe Moreira Lacerda; FORTES, Mariana Flesch. Trabalho Escravo: Reflexões sobre a responsabilidade na cadeia produtiva. Revista do Ministério Público do Trabalho, Brasília, ano XXIV, $\mathrm{n}^{\circ}$. 48. São Paulo: Ltr, 2015. p. 68. Disponível em: < http://www.tridiacriacao.com/clientes/anpt/images/olds/arquivos/revista-MPT-48_anpt23121.pdf >. Acesso em 04 out.. 2017.

${ }^{67}$ BRASIL. Ministério Público do Trabalho. Procuradoria Regional do Trabalho da 2a Região. Ação Civil Pública. Réu: M5 Indústria e Comércio Ltda. 2014. Disponível em: $<$ http://reporterbrasil.org.br/documentos/acp-mofficer.pdf>. Acesso em 14 jul. 2017
} 
impróprio de objetos pessoais, da comida e do lixo produzido, além das demais irregularidades citadas anteriormente.

Nesse liame, se faz obrigatória a adequação do espaço físico no qual a atividade laboral é exercida aos ditames de saúde, higiene e segurança do trabalho, presentes não apenas na CLT, como também nas NRs do Ministério do Trabalho.

A CLT, em seu art. 157, estabelece a obrigação genérica das empresas em cumprir com as normas de segurança e medicina do trabalho ${ }^{68}$, cabendo citar dentre elas, aquelas que essencialmente versam sobre a responsabilidade dos envolvidos no dano ambiental:

NR n ${ }^{\circ} 1-$ DIPOSIÇÕES GERAIS

1.1. As Normas Regulamentadoras - NR, relativas à segurança e medicina do trabalho, são de observância obrigatória pelas empresas privadas e públicas e pelos órgãos públicos da administração direta e indireta, bem como pelos órgãos dos Poderes Legislativo e Judiciário, que possuam empregados regidos pela Consolidação das Leis do Trabalho - CLT. (grifo nosso)

NR n 5 - COMISSÃO INTERNA DE PREVENÇÃO DE ACIDENTES - CIPA

5.50 A empresa contratante adotará as providências necessárias para acompanhar o cumprimento pelas empresas contratadas que atuam no seu estabelecimento, das medidas de segurança e saúde no trabalho. (grifo nosso)

NR $\mathrm{n}^{\circ} 10$ - SEGURANÇA EM INSTALAÇÕES E SERVIÇOS EM ELETRICIDADE

10.13.1 As responsabilidades quanto ao cumprimento desta NR são solidárias aos contratantes e contratados envolvidos. (grifo nosso)

NR $n^{\circ} 31$ - SEGURANÇA E SAÚDE NO TRABALHO NA AGRICULTURA, PECUÁRIA SILVICULTURA, EXPLORAÇÃO FLORESTAL E AQUICULTURA

\subsubsection{Responderão solidariamente pela aplicação desta Norma}

Regulamentadora as empresas, empregadores, cooperativas de produção ou parceiros rurais que se congreguem para desenvolver tarefas, ou que constituam grupo econômico.

31.3.3.2 Sempre que haja dois ou mais empregadores rurais ou trabalhadores autônomos que exerçam suas atividades em um mesmo local, estes deverão

\footnotetext{
${ }^{68}$ BRASIL. Ministério Público do Trabalho. Procuradoria Regional do Trabalho da $2^{\text {a }}$ Região. Ação Civil Pública. Réu: M5 Indústria e Comércio Ltda. 2014. Disponível em: $<$ http://reporterbrasil.org.br/documentos/acp-mofficer.pdf $>$. Acesso em 14 jul. 2017
} 
colaborar na aplicação das prescricões sobre segurança e saúde. (grifos nossos)

Destaca-se que, embora a NR $n^{\circ} 31$ trate de trabalhadores que exerçam atividades no meio rural, é evidente que a responsabilidade solidária, por se constituir medida protetiva, também deverá ser extendida aos trabalhadores urbanos, uma vez que a Constituição prevê, em seu art. $7^{\circ}$, caput, a igualdade substancial entre empregados urbanos e rurais.

Em caráter complemetar, também é possível fazer referência à responsabilidade objetiva e solidária de todos os que se beneficiam da atividade empresarial à custa da degradação do meio ambiente, prevista no $\S 1^{\circ}$, do art. 14, da Política Nacional do Meio Ambiente, senão vejamos:

Art 14 - Sem prejuízo das penalidades definidas pela legislação federal, estadual e municipal, o não cumprimento das medidas necessárias à preservação ou correção dos inconvenientes e danos causados pela degradação da qualidade ambiental sujeitará os transgressores:

$\S 1^{\circ}$ - Sem obstar a aplicação das penalidades previstas neste artigo, é o poluidor obrigado, independentemente da existência de culpa, a indenizar ou reparar os danos causados ao meio ambiente e a terceiros, afetados por sua atividade. O Ministério Público da União e dos Estados terá legitimidade para propor ação de responsabilidade civil e criminal, por danos causados ao meio ambiente. (grifo nosso)

Ademais, segue jurisprudência pátria que reconhece a responsabilidade solidária e objetiva por dano ao meio ambiente do trabalho:

MEIO AMBIENTE DO TRABALHO. RESPONSABILIDADE SOLIDÁRIA. PRINCÍPIO DO APRIMORAMENTO CONTÍNUO. CONVENÇÃO 155 DA OIT. SUPRALEGALIDADE. A responsabilidade solidária entre tomador e prestador de serviços pela garantia de higidez do meio ambiente laboral foi consagrada no artigo 17 da Convenção 155 da OIT, ratificada em 1992. Referida convenção traz disposições que denotam o dever empresarial de aprimoramento contínuo da segurança no trabalho, a fim de implementar novas técnicas que evitem a ocorrência de infortúnios, garantindo a preservação da saúde e integridade física dos trabalhadores, empregados ou terceirizados. Importante destacar prevalece, no Brasil, a tese da supralegalidade, ou seja, os tratados de direitos humanos possuem, no mínimo, nível supralegal, caso não tenham sido aprovados com o quórum qualificado instituído pela EC 45/2004 (que acrescentou o parágrafo $3^{\circ}$ ao artigo $5^{\circ}$ da CRFB/88). Tais dispositivos de estatura supralegal integram, assim, o chamado bloco de constitucionalidade, 
previsto no parágrafo $2^{\circ}$ do artigo $5^{\circ}$ da $\mathrm{CRFB} / 88$, como normas materialmente constitucionais. Respondem solidariamente, portanto, a tomadora e a prestadora do trabalho pelos danos sofridos pelo trabalhador em decorrência de inadequação do meio ambiente de trabalho, com observância do princípio da restituição integral para o arbitramento das indenizações (artigos $1^{\circ}$, III e $3^{\circ}$, I da Constituição da República e artigos 944 e 949 do Código Civil).

(TRT 3 ${ }^{\mathrm{a}}$ Região. Décima Primeira Turma. 0010234-33.2014.5.03.0134 (PJe). RECURSO ORDINÁRIO. Rel. Adriana Goulart de Sena Orsini. DEJT/TRT3/Cad. Jud. 25/05/2017, P.1208) - (grifo nosso)

Por assim dizer, considerando que a precariedade do meio ambiente do trabalho que contribui para o prejuízo da saúde e segurança do trabalhador pode ser interpretada como poluição ao meio ambiente, fato é que todos os empregadores que concorreram para este dano direta ou indiretamente deverão ser responsáveis solidários, tendo de arcar com as despesas de prevenção, repressão e reparação da poluição causada. ${ }^{69}$

Desse modo, estando a magazine elencada dentro da cadeia de empregadores, será dela também o ônus garantir a aplicação das normas de medicina e proteção do trabalho nas células produtivas que compõem sua rede de manufatura, valendo-se da fiscalização efetiva e da aplicação de penalidade de descredenciamento de empresas subcontratadas em situação irregular como principal instrumento para erradicar o trabalho análogo ao escravo em condições degradantes.

\footnotetext{
${ }^{69}$ BRASIL. Ministério Público do Trabalho. Procuradoria Regional do Trabalho da $2^{\mathrm{a}}$ Região. Ação Civil Pública. Réu: M5 Indústria e Comércio Ltda. 2014. Disponível em: $<$ http://reporterbrasil.org.br/documentos/acp-mofficer.pdf>. Acesso em 14 jul. 2017
} 


\section{PARTE V - CASO PARADIGMÁTICO: ZARA}

A grife espanhola ZARA, que apresenta razão social de Zara Brasil Ltda. em âmbito nacional, pertence ao Grupo Inditex e está listada entre as marcas de vestuário mais valiosas do mundo ( $3^{\circ}$ lugar), avaliada em aproximadamente US\$14,4 bilhões neste ano de $2017^{70}$, perdendo apenas para Nike $\left(1^{\circ}\right)$ e $H \& M\left(2^{\circ}\right)$.

Sua cadeia de manufatura depende de diversas intermediárias para a efetividade da confecção de suas roupas, como as fornecedoras Rhodes e AHA Indústria e Comércio de Roupas Ltda., vez que não possui capacidade produtiva suficiente para atender à proposta de mercado fast fashion da marca por si só, o que culmina na possível subcontratação em cascata de trabalhadores, na falta de controle de supervisão na aplicação de seus direitos trabalhistas e, consequentemente, na ocorrência de trabalho imigrante análogo ao escravo.

Nesse sentido, iremos adiante analisar os casos de flagrantes realizados na Grande São Paulo de trabalhadores encontrados em condições subumanas, em oficinas clandestinas, que ficaram notoriamente conhecidos por envolver a grande marca ZARA.

O primeiro caso de flagrante ocorreu em maio/2011, em uma facção especializada na produção de calças e bermudas - chamada Oficina de Narciso Atahuichy Choque - localizada no município de Americana, interior de São Paulo, que prestava serviços de costura para a empresa ZARA por intermédio da fornecedora Rhodes ${ }^{71}$.

\footnotetext{
${ }^{70}$ O GLOBO. Ranking lista as marcas de vestuário mais valiosas do mundo em 2017. 13/03/2017. Disponível em: <https://oglobo.globo.com/ela/moda/ranking-lista-as-marcas-de-vestuario-maisvaliosas-do-mundo-em-2017-21051051>. Acesso em 05 out. 2017.

71 PYL, Bianca; HASHIZUME, Maurício. Roupas da Zara são fabricadas com mão de obra escrava. In: Repórter Brasil. 16/08/2011. Disponível em: $<$ http://reporterbrasil.org.br/2011/08/roupas-da-zara-sao-fabricadas-com-mao-de-obra-escrava/>. Acesso em 05 out. 2017.
} 
Frisa-se que $70 \%{ }^{72}$ da produção da facção Narciso era destinada à confecção Rodhes, o que demonstra uma clara dependência entre os estabelecimentos, além de figurar como meio facilitador de fraudes.

Na ocasião, a operação identificou a presença de 52 trabalhadores, sendo 46 deles bolivianos e um peruano, todos em situação irregular que, por maioria, foram aliciados em seu local de origem e transportados por meio de empréstimos do empregador - ou de seu preposto - até o local de trabalho. ${ }^{73}$

O tráfico de pessoas em cumulação à servidão por dívida e por retenção de documentos pôde ser comprovado a partir da apreensão de dois cadernos pelos auditores fiscais com anotações de dívidas sob a nomenclatura de "passagem", “documentos" e "vales".74

Nota-se que, desde então, a violação de direitos já tem início, sendo verificada a incidência do art. 149, caput e inciso II, do CP, no que se refere à escravidão por dívida e retenção de documentos, cumulado com o art. 149-A, incisos II e III, do mesmo diploma legal, que configura o tráfico por meio de aliciamento e transporte de pessoas com a finalidade de submeter o traficado a trabalho análogo ao escravo.

Quanto à cobrança de dívidas de transporte do trabalhador para o local de execução de trabalho, é possível fazermos uma interpretação analógica do art. $207, \S 1^{\circ}$, do $\mathrm{CP}$, que trata como crime o recrutamento de trabalhadores em território nacional mediante cobrança de qualquer quantia,

72 PYL, Bianca; HASHIZUME, Maurício. Roupas da Zara são fabricadas com mão de obra escrava. In: Repórter Brasil. 16/08/2011. Disponível em: $<$ http://reporterbrasil.org.br/2011/08/roupas-da-zara-sao-fabricadas-com-mao-de-obra-escrava/>. Acesso em 05 out. 2017.

73 PYL, Bianca; HASHIZUME, Maurício. Roupas da Zara são fabricadas com mão de obra escrava. In: Repórter Brasil. 16/08/2011. Disponível em: $<$ http://reporterbrasil.org.br/2011/08/roupas-da-zara-sao-fabricadas-com-mao-de-obra-escrava/>. Acesso em 05 out. 2017.

74 PYL, Bianca; HASHIZUME, Maurício. Roupas da Zara são fabricadas com mão de obra escrava. In: Repórter Brasil. 16/08/2011. Disponível em: $<$ http://reporterbrasil.org.br/2011/08/roupas-da-zara-sao-fabricadas-com-mao-de-obra-escrava/>. Acesso em 05 out. 2017. 
conjuntamente com o art. 470 da CLT, que é incisivo quanto à responsabilidade do empregador no que tange às despesas resultantes de transferência do obreiro, para chegarmos à conclusão de que o transporte destes imigrantes para laborar em uma oficina brasileira não deveria ser um encargo por eles assumido.

Convém também citar que as "passagens" e "vales" discriminados nas anotações encontradas pelos ficais podem significar uma espécie de sistema de barracão, prática vedada pelo art. 462 , caput e $\S 2^{\circ}$, da CLT, ou pagamento in natura, que deve ser excepcionado de acordo com arts. 82, PU, e 463 da CLT, limitando-se a 70\% o pagamento em utilidades.

No mais, outro tipo de escravidão também foi claramente identificada na fiscalização, qual seja, aquela em que o trabalhador se submete a situações tão degradantes que afrontam de pronto sua dignidade humana.

Nesse liame, constatou-se que os alojamentos e o ambiente de trabalho se encontravam em total condição precária, apresentando graves violações às normas de saúde e segurança do trabalho, senão vejamos:

Além da sujeira, os trabalhadores conviviam com o perigo iminente de incêndio, que poderia tomar grandes proporções devido à grande quantidade de tecidos espalhados pelo chão e à ausência de janelas, além da falta de extintores. Após um dia extenuante de trabalho, os costureiros e seus filhos eram obrigados a tomar banho frio. Os chuveiros permaneciam desligados para evitar a sobrecarga nas instalações elétricas, feitas sem nenhum cuidado ${ }^{75}$ (grifos nossos)

A oficina funcionava em um imenso galpão de dois andares. No andar superior, ficavam os alojamentos e a cozinha. No inferior, as máquinas. A fiação elétrica estava exposta e o local era muito sujo. Havia um bebedouro, porém somente um copo plástico para todos dividirem. Os pequenos quartos abrigavam famílias inteiras e grupos de até cinco trabalhadores. Alguns cômodos tinham

75 PYL, Bianca; HASHIZUME, Maurício. Roupas da Zara são fabricadas com mão de obra escrava. In: Repórter Brasil. 16/08/2011. Disponível em: $<$ http://reporterbrasil.org.br/2011/08/roupas-da-zara-sao-fabricadas-com-mao-de-obra-escrava/>. Acesso em 05 out. 2017. 
alimentos espalhados, armazenados de forma inadequada.${ }^{76}$ (grifos nossos)

Tais condições ferem, dentre diversas normas, os arts. 157 e 389 da CLT, que elencam as obrigações mínimas do empregador no que se refere às precauções a serem tomadas em segurança e medicina do trabalho. Ainda, podemos falar do art. 170 e seguintes da CLT, bem como, das NRs $\mathrm{n}^{\text {os }} 10$ (Segurança em Instalações e serviços em eletricidade), 23 (Proteção Contra Incêndios) e 24 (Condições Sanitárias e de Conforto nos Locais de Trabalho), que estabelecem requisitos de indispensável cumprimento para que o ambiente laboral possa garantir segurança aos que nele trabalham.

Ressalta-se que o risco iminente à possibilidade de incêndio e a exposição contínua à fiação elétrica caracterizam a atividade realizada na oficina como perigosa, o que enseja o necessário fornecimento pelo empregador de Equipamentos de Proteção Individual (EPIs) aos seus trabalhadores, segundo o art. 166 da CLT e NRs n ${ }^{\text {os }} 6$ (Equipamentos de Proteção Individual - EPI) e 16 (Atividades e Operações Perigosas), bem como, a percepção de adicional de periculosidade no importe de $30 \%$ sobre o salário base, conforme art. 193 da CLT.

No que diz respeito especificamente aos alojamentos, estes quase que confundidos com a estrutura da própria oficina, o $\S 4^{\circ}$ do art.458 da CLT veda a coabitação de mais de uma família em uma mesma unidade residencial fornecida pelo empregador como salário utilidade, o que é notoriamente desrespeitado segundo o mencionado nos trechos em análise.

Ademais, as condições em que se dava a atividade laboral e a percepção de remuneração também eram igualmente aviltantes, conforme se segue:

Um grupo de trabalhadores costurava uma calça jeans da Coleção PrimaveraVerão da Zara. Cada trabalhador fazia uma parte da peça e o valor de, em média,

\footnotetext{
76 PYL, Bianca; HASHIZUME, Maurício. Roupas da Zara são fabricadas com mão de obra escrava. In: Repórter Brasil. 16/08/2011. Disponível em: $<$ http://reporterbrasil.org.br/2011/08/roupas-da-zara-sao-fabricadas-com-mao-de-obra-escrava/>. Acesso em 05 out. 2017.
} 
$\underline{\text { RS 1,80, era dividido pelo grupo todo, composto por sete pessoas. }}{ }^{77}$ (grifo nosso)

Os cadernos mostram alguns dos salários recebidos pelos empregados: de R $\$ 274$ a $\mathrm{R} \$ 460$, bem menos que o salário mínimo vigente no país, que é de $\mathrm{R} \$ 545{ }^{78}$ (grifo nosso)

As cadeiras nas quais os trabalhadores passavam sentados por mais de 12 horas diárias eram_completamente improvisadas. Alguns colocavam espumas para torná-las mais confortáveis. As máquinas de costura não possuíam aterramento e tinham a correia toda exposta $(\ldots)^{79}$ (grifos nossos)

(...) incluía contratacões completamente ilegais, trabalho infantil, condicões degradantes, iornadas exaustivas de até $16 \mathrm{~h}$ diárias e cerceamento de liberdade (seja pela cobrança e desconto irregular de dívidas dos salários, o truck system, seja pela proibição de deixar o local de trabalho sem prévia autorização). Apesar do clima de medo, um dos trabalhadores explorados confirmou que só conseguia sair da casa com a autorização do dono da oficina, concedida apenas em casos urgentes, como quando teve de levar seu filho às pressas ao médico. ${ }^{80}$ (grifo nosso)

Resta evidente que o salário percebido pelos que laboravam na oficina, mesmo em se tratando de remuneração por peça, não satisfazia o mínimo garantido por lei, arts. 78 e 83 da CLT, e na Constituição, art. $7^{\circ}$, inciso VII, sendo uma forma de perpetuar o estado de miséria ali instaurado, não permitindo que o costureiro exercesse uma gama de direitos advindos da remuneração digna, como o direito à moradia, alimentação, educação, saúde, lazer, vestuário, dentre outros.

Também nos deparamos com a falta de cumprimento ao art. 199 da CLT e NR $n^{\circ} 17$ (Ergonomia) que obrigam o empregador a fornecer

77 PYL, Bianca; HASHIZUME, Maurício. Roupas da Zara são fabricadas com mão de obra escrava. In: Repórter Brasil. 16/08/2011. Disponível em: $<$ http://reporterbrasil.org.br/2011/08/roupas-da-zara-sao-fabricadas-com-mao-de-obra-escrava/>. Acesso em 05 out. 2017.

78 PYL, Bianca; HASHIZUME, Maurício. Roupas da Zara são fabricadas com mão de obra escrava. In: Repórter Brasil. 16/08/2011. Disponível em: $<$ http://reporterbrasil.org.br/2011/08/roupas-da-zara-sao-fabricadas-com-mao-de-obra-escrava/>. Acesso em 05 out. 2017.

79 PYL, Bianca; HASHIZUME, Maurício. Roupas da Zara são fabricadas com mão de obra escrava. In: Repórter Brasil. 16/08/2011. Disponível em: $<$ http://reporterbrasil.org.br/2011/08/roupas-da-zara-sao-fabricadas-com-mao-de-obra-escrava/>. Acesso em 05 out. 2017.

${ }^{80}$ PYL, Bianca; HASHIZUME, Maurício. Roupas da Zara são fabricadas com mão de obra escrava. In: Repórter Brasil. 16/08/2011. Disponível em: $<$ http://reporterbrasil.org.br/2011/08/roupas-da-zara-sao-fabricadas-com-mao-de-obra-escrava/>. Acesso em 05 out. 2017. 
assentos que sejam ergonometricamente adequados ao trabalhador que exerce suas tarefas essencialmente sentado, situação muito comum aos que laboram em oficinas de confecção e costura - o relato exposto faz referência ao total de $12 \mathrm{~h}$ diárias em que os trabalhadores permanecem sentados na oficina.

Não somente os utensílios acessórios - a exemplo das cadeiras - para o exercício do trabalho se encontravam em situação deplorável, como a própria máquina de costura dos trabalhadores não estava em seguras condições para ser utilizada - não possuindo aterramento e apresentando a correia exposta, em clara afronta aos arts. 184 e 185 da CLT e à NR n ${ }^{\circ} 12$ (Segurança no Trabalho em Máquinas e Equipamento).

Um dos trechos supracitados também faz referência ao trabalho infantil encontrado nas oficinas, o qual é expressamente rechaçado pelos arts. $7^{\circ}$, inciso XXXIII, da CF e 403 da CLT, não sendo possível o trabalho de menor de 16 anos de idade, salvo na condição de aprendiz a partir dos 14 anos, estando, contudo, vedada a contratação de qualquer menor de 18 anos para o exercício de trabalho noturno e em condições perigosas e/ou insalubres, o que de fato acontecia na facção.

Ainda, temos a ocorrência do trabalho análogo ao escravo por jornadas exaustivas, ante as aludidas $16 \mathrm{~h}$ de trabalho diárias praticadas pelos imigrantes, violando-se o limite de $8 \mathrm{~h}$ normais de trabalho e $2 \mathrm{~h}$ suplementares, previsto nos arts. $7^{\circ}$, inciso XIII, da CF e 58 e 59 da CLT, além de igualmente estar sendo desrespeitado o intervalo interjornada mínimo de $11 \mathrm{~h}$ consecutivas para descanso do trabalhador, previsto no art. 66 da CLT, o que enseja o recebimento de respectivo adicional por hora extra de 50\%, nos termos do art. $7^{\circ}$, inciso XVI, da CF e da OJ n ${ }^{\circ} 235$ da SDI-1 - ressalta-se que esta orientação jurisprudencial dita que, em se tratando de salário por produção, no caso de sobrejornada, fará o trabalhador a percepção somente do adicional. 
Por fim, resta citar a questão dos trabalhadores serem impedidos de sair do ambiente de trabalho sem a autorização do empregador, o que pode ser enquadrado no art. 197 do CP, como crime de constranger alguém a trabalhar, cumulado com o art. 148 do $\mathrm{CP}$, crime de cárcere privado, violando-se o direito de locomoção do indivíduo assegurado no art. 5, inciso XV, da CF.

Fato é que esta primeira investigação culminou na inspeção de junho/2011, em que o MPT encontrou em outras duas oficinas localizadas no centro e zona norte de São Paulo 16 pessoas trabalhando em condições degradantes, sendo 15 delas bolivianas, na produção de peças para a ZARA sob o intermédio da AHA Indústria e Comércio de Roupas Ltda. ${ }^{81}$

A AHA foi a principal fornecedora da ZARA, tendo sido a fabricante que teve o maior faturamento durante o período auditado pela fiscalização (julho/2010 - maio/2011), com a produção de peças para a grife de até $91 \%$ do seu total (2011).

Sua atuação restringia-se em apenas simplesmente intermediar o vínculo entre os trabalhadores das facções e a marca espanhola, vez que ao mesmo tempo em que foi constatada a redução drástica de trabalhadores no quadro de funcionários da fornecedora no período de ascensão relatado - de 100 funcionários para 20 -, também foi apurado que a grife comandava todo o processo de produção, desde a escolha dos tecidos. ${ }^{82}$

Após os flagrantes supracitados, a ZARA assinou, em 19.12.2011, junto ao MPT da $2^{\text {a }}$ Região - SP e do MT, TAC que previa, dentre diversas atribuições, o pagamento de $\mathrm{R} \$ 50.000,00$ para fundo emergencial gerenciado por instituições de apoio ao imigrante por cada subcontratado

81 CAMPOS, André. Zara corta oficinas de imigrantes e será multada por discriminação. In: Repórter Brasil. 09/05/2015. Disponível em: <http://reporterbrasil.org.br/2015/05/zara-cortaoficinas-de-imigrantes-e-sera-multada-por-discriminacao/>. Acesso em 05 out. 2017.

82 PYL, Bianca; HASHIZUME, Maurício. Roupas da Zara são fabricadas com mão de obra escrava. In: Repórter Brasil. 16/08/2011. Disponível em: $<$ http://reporterbrasil.org.br/2011/08/roupas-da-zara-sao-fabricadas-com-mao-de-obra-escrava/>. Acesso em 05 out. 2017. 
encontrado em situação irregular, além de investimento social mínimo no valor de R $\$ 3.477 .831,22$ em ações preventivas e corretivas no setor têxtil. ${ }^{83}$

O mencionado termo previa, ainda, a responsabilidade da marca pela verificação das condições de trabalho de seus fornecedores e terceirizados, o que de praxe já deveria ser observado pela empresa. Segue cláusula que trata da matéria:

1.4. Em função das considerações acima, as partes celebram o presente TAC, que contempla as seguintes diretrizes, a serem detalhadas no curso deste instrumento:

B) Assunção de responsabilidade, pela ZARA BRASIL, por verificação das condições de trabalho observadas nos FORNECEDORES e TERCEIROS no $\operatorname{Brasil}(\ldots)^{84}$

Cumpre ressaltar, entretanto, que a ZARA ignorou os mecanismos de apoio aos imigrantes determinados no TAC e passou a adotar uma política discriminatória na contratação de seus funcionários, excluindo parte dos trabalhadores estrangeiros de sua cadeia produtiva e transferindo uma parcela de sua produção para outras localidades. ${ }^{85}$

Em caráter simultâneo, a multinacional propôs Ação Anulatória (Processo $n^{o}$ 0001662-91.2012.502.0003) requerendo a invalidação dos Autos de Infração lavrados na ocasião das fiscalizações de 2011 e, consequentemente, a sua não inclusão no cadastro de empregadores que se beneficiam de mão de obra em situação análoga à escrava, chamado "lista suja" da escravidão (Portaria $n^{\circ} 540$ ) do MT, sob o argumento falho de que não tinha conhecimento das condições a que os trabalhadores eram

${ }^{83}$ BRASIL. Termo de Ajuste de Conduta. (Inquérito Civil n. 0000393.2011.02.002/2).

Disponível em: <http://www.prt2.mpt.mp.br/servicos/termos-de-ajuste-deconduta?task=baixa\&format=raw\&arq=ni 8-fI9oenKbxgoYerWk9G4wOwcQS-

kOKDDc50_A5LnHKjjw5580YGGKFeacs-ayJWKwwshHY-3QS4q1X7YXw >. Acesso em: 06 out. 2017.

${ }^{84}$ BRASIL. Termo de Ajuste de Conduta. (Inquérito Civil n. 0000393.2011.02.002/2).

Disponível em: $\quad<$ http://www.prt2.mpt.mp.br/servicos/termos-de-ajuste-deconduta?task=baixa\&format=raw\&arq=ni_8-f19oenKbxgoYerWk9G4wOwcQS-

kOKDDc50_A5LnHKjjw5580YGGKFeacs-ayJWKwwshHY-3QS4q1X7YXw >. Acesso em: 06 out. 2017. p. 2.

85 MANSOLDO, Felipe Fayer. Considerações sobre o Caso Zara do Brasil e a possível inadequação do compromisso de ajustamento de conduta como resposta eficaz às violações de direitos humanos. Disponível em: <http:/homacdhe.com/dialogossobredireitoshumanos/wpcontent/uploads/sites/5/2017/02/CASO-ZARA.pdf>. Acesso em 08 out. 2017. 
submetidos nas oficinas de costura, sendo de responsabilidade das confecções intermediárias o descumprimento das normas trabalhistas, além de invocar o TAC assinado como sinal de seu comprometimento com o Poder Público e com ações sociais. ${ }^{86}$

Em sede de primeira instância, na data de 11.04.2014, o juiz Álvaro Emanuel de Oliveira Simões, da $3^{\mathrm{a}}$ Vara do Trabalho de São Paulo, reconheceu a ZARA como real empregadora dos imigrantes que laboravam em condições subumanas nas facções produtoras das peças de vestuário da grife, entendendo pela sua responsabilidade direta diante da ocorrência de uma subordinação camuflada de terceirização dos costureiros para com a multinacional, bem como, por esta adquirir mais de $90 \%$ da produção da intermediária AHA. Ademais, o magistrado também cassou a liminar que impedia a inserção da grife na "lista suja". ${ }^{87}$ Nesse sentido, seguem trechos da sentença que apontam os supracitados elementos de convicção do juízo:

2.2. PEDIDOS Afirma a autora, a escorar sua pretensão à declaração de nulidade dos autos, não haver praticado nenhum ato ilícito e que o Ministério do Trabalho e Emprego teria extrapolado os limites de suas atribuições ao reconhecê-la como real empregadora de pessoas encontradas em condições análogas à de escravo em oficinas cujo objetivo era a confecção de peças de vestuário da marca Zara. Diz ainda que o órgão não poderia expedir atos normativos criando o que apelida de "Lista Suja", pois estaria, ao fazê-lo, invadindo competência privativa do Poder Legislativo, e que a multa fixada no Auto de Infracão n ${ }^{0} 021505799$ teria excedido o teto legal ${ }^{88}$ (grifos nossos)

A celebracão de TAC com o Ministério Público do Trabalho, embora louvável, foi posterior à autuação, não implicando, logicamente, nenhuma influência no resultado da lide, por não convalidar situação pretérita. Chega a ser insólito, de outra banda, o longo discurso derredor de conduta da entidade capitalista, igualmente posterior à lavratura dos Autos e igualmente desinfluente para o deslinde desta contenda, no sentido de prática de ações de certa repercussão social, cujo objetivo primordial foi, sem dúvida, a recuperação da imagem da marca, imensamente desgastada pela repercussão dos resultados da

\footnotetext{
${ }^{86}$ G1. Justiça de SP mantém ação contra Zara por trabalho escravo. 15/04/2014. Disponível em: $<$ http://g1.globo.com/sao-paulo/noticia/2014/04/justica-de-sp-mantem-acao-contra-zara-portrabalho-escravo.html>. Acesso em 06 out. 2017.

87 REPÓRTER BRASIL. Íntegra da sentença judicial em que Zara é responsabilizada por escravidão. 14/04/2014. Disponível em <http://reporterbrasil.org.br/2014/04/integra-da-sentencajudicial-em-que-zara-e-responsabilizada-por-escravidao/>. Acesso em 06 out.2017.

88 REPÓRTER BRASIL. Íntegra da sentença judicial em que Zara é responsabilizada por escravidão. 14/04/2014. Disponível em <http://reporterbrasil.org.br/2014/04/integra-da-sentencajudicial-em-que-zara-e-responsabilizada-por-escravidao/>. Acesso em 06 out.2017.
} 
fiscalização na mídia. ${ }^{89}$ (grifo nosso)

O cerne da tese ali esgrimida é a pretensa licitude da intermediação, para a Aha Indústria e Comércio Ltda., da manufatura dos produtos comercializados pela Zara Brasil Ltda., afirmando esta que a primeira seria a real contratante dos trabalhadores encontrados em situação precária, e que teria autonomia empresarial, atendendo a diversas marcas suas clientes. Disse mais, que a Aha, ainda no curso da fiscalização, procedeu à regularização do registro dos trabalhadores, assumindo inteira responsabilidade por eles. Constata-se, todavia, que a suposta independência financeira da Aha não se encontra demonstrada nos autos, não servindo a tanto, logicamente, simples catálogo eletrônico, exibido na internet, desde o qual não é possível saber da existência física das roupas ou de clientes. Sabe-se, em oposição, ter sido constatado ser a Zara a adquirente de mais de $90 \%$ da produção da Aha, caracterizando-se, na prática, um monopsônio. ${ }^{90}$ (grifos nossos)

Diante de tamanha desproporcão no poderio econômico entre fornecedora e compradora, a assunção de responsabilidade pela Aha, quanto ao destino dos trabalhadores, não é indício minimamente consistente de que tenha agido sponte sua ao subcontratar as oficinas, sem conhecimento, anuência ou, até, determinação por parte da Zara. ${ }^{91}$ (grifo nosso)

Voltando-se à vertente principal, vê-se que a Aha, ao contrário do que assevera a demandante, não tinha porte para servir de grande fornecedora, $\mathrm{e}$ disto ela estava perfeitamente ciente, pois, realizando auditorias sistemáticas, sabia do extenso downsizing realizado, com o número de costureiras da Aha caindo mais de $80 \%$, ao tempo em que a produção destinada à Zara crescia. A fiscalização verificou, outrossim, que as oficinas onde foram encontrados trabalhadores em condição análoga à de escravidão labutavam exclusivamente na fabricacão de produtos da Zara, atendendo a critérios e especificacões apresentados pela empresa, recebendo seu escasso salário de repasse oriundo, também exclusivamente, ou quase exclusivamente, da Zara.

A fraude da intermediacão é escancarada, pois, na verdade, houve prestacão em favor da vindicante com pessoalidade, não eventualidade, remuneração $\mathrm{e}$ subordinação econômica, requisitos alinhados no art. $3^{\circ}$ do texto celetário, e, repita-se, a subordinação, embora camuflada sob a aparência de ${\text { terceirizacão, era direta aos desígnios da comerciante das confeccões. }{ }^{92}}^{92}$ (grifos nossos)

A Zara Brasil Ltda. é uma das maiores corporações do globo, em seu ramo de negócio, custando crer, reitere-se, que tivesse controles tão frouxos da conduta de seus fornecedores, mostrando-se muito mais palatável a versão defendida pela

${ }^{99}$ REPÓRTER BRASIL. Íntegra da sentença judicial em que Zara é responsabilizada por escravidão. 14/04/2014. Disponível em <http://reporterbrasil.org.br/2014/04/integra-da-sentencajudicial-em-que-zara-e-responsabilizada-por-escravidao/>. Acesso em 06 out.2017.

${ }_{90}$ REPÓRTER BRASIL. Íntegra da sentença judicial em que Zara é responsabilizada por escravidão. 14/04/2014. Disponível em <http://reporterbrasil.org.br/2014/04/integra-da-sentencajudicial-em-que-zara-e-responsabilizada-por-escravidao/>. Acesso em 06 out.2017.

${ }_{91}$ REPÓRTER BRASIL. Íntegra da sentença judicial em que Zara é responsabilizada por escravidão. 14/04/2014. Disponível em <http://reporterbrasil.org.br/2014/04/integra-da-sentencajudicial-em-que-zara-e-responsabilizada-por-escravidao/>. Acesso em 06 out.2017.

92 REPÓRTER BRASIL. Íntegra da sentença judicial em que Zara é responsabilizada por escravidão. 14/04/2014. Disponível em <http://reporterbrasil.org.br/2014/04/integra-da-sentencajudicial-em-que-zara-e-responsabilizada-por-escravidao/>. Acesso em 06 out.2017. 
fiscalização, de que, na realidade, controlava-os ao ponto de deter a posição de empregadora. Assim, ainda que entendida não ser atividade-fim da companhia a manufatura dos produtos, o que, de resto, é dúbio, em face do depoimento da primeira testemunha, a terceirização é ilegal quando há subordinação direta ${ }^{93}$ (grifos nossos)

Indeferem-se, em face de tudo quanto exposto, os pedidos de declaração de nulidade do relatório de fiscalização do MTE, anulação dos Autos de infração listados na peça vestibular, redução do valor do Auto $\mathrm{n}^{0}$ 021505799, determinação de que a empresa não seja incluída na "lista suja", ou seja, no Cadastro de Empregadores que mantiveram trabalhadores em condições análogas à de escravo, determinação de que a autora não seja inscrita na dívida ativa nem no cadastro de inadimplentes e demais pedidos destes acessórios. ${ }^{94}$ (grifos nossos)

Não obstante o TAC firmado em 2011 e a validade dos Autos de Infração lavrados no mesmo ano, foi verificada a ocorrência de nova situação envolvendo trabalho análogo ao escravo no período de 14 de agosto a 23 de setembro de $2013^{95}$ dentro da cadeia produtiva da magazine, mas que somente veio a conhecimento público em novembro/2014, por meio do resgate de 37 trabalhadores que, na ocasião, produziam para a marca Renner, sendo encontradas mais de 8 mil peças de vestuário na oficina costuradas para a ZARA - não havendo a responsabilização desta última pela ausência de flagrante. ${ }^{96}$

À ONG Repórter Brasil, dois bolivianos que foram resgatados relataram as seguintes condições de trabalho vivenciadas à época em que a produção se destinava à grife ZARA:

A gente começava a trabalhar às seis da manhã e ía até às nove da noite, às vezes meia noite. Mas a mulher que batia nosso ponto marcava sempre o horário das sete da manhã às seis da tarde.

93 REPÓRTER BRASIL. Íntegra da sentença judicial em que Zara é responsabilizada por escravidão. 14/04/2014. Disponível em <http://reporterbrasil.org.br/2014/04/integra-da-sentencajudicial-em-que-zara-e-responsabilizada-por-escravidao/>. Acesso em 06 out.2017.

94 REPÓRTER BRASIL. Íntegra da sentença judicial em que Zara é responsabilizada por escravidão. 14/04/2014. Disponível em <http://reporterbrasil.org.br/2014/04/integra-da-sentencajudicial-em-que-zara-e-responsabilizada-por-escravidao/>. Acesso em 06 out.2017.

95 AGÊNCIA BRASIL. Zara é autuada por não cumprir acordo para acabar com trabalho escravo. In: Carta Capital. 13/05/2015. Disponível em: <https:/www.cartacapital.com.br/economia/zara-eautuada-por-nao-cumprir-acordo-para-acabar-com-trabalho-escravo-8409.html>. Acesso em 06 out.2017.

96 CAMPOS, André. Zara corta oficinas de imigrantes e será multada por discriminação. In: Repórter Brasil. 09/05/2015. Disponível em: <http://reporterbrasil.org.br/2015/05/zara-cortaoficinas-de-imigrantes-e-sera-multada-por-discriminacao/>. Acesso em 05 out. 2017. 
O trabalho era cronometrado. Se não tirasse 30 pecas em uma hora, ela descontava como hora incompleta. Depois tinha que trabalhar mais.

Tinha um gerente muito violento. Ele levava uma faca na cintura, gritava com a gente, mandava limpar o chão do banheiro. Ele bateu em um funcionário na nossa frente.

Tinha uma adolescente trabalhando lá e duas crianças, que ficavam no meio das máquinas.

A dona ficava com o nosso salário, ela mentia, dizia que o banco brasileiro cobra taxa de juros alta. A gente tinha acabado de chegar, confiamos nela.

Trabalhamos muito um ano inteiro, economizando, sem gastar nada que não fosse preciso. A dona guardava tudo. Depois ela disse que não podia devolver nosso dinheiro, que a gente procurasse a justiça. Até hoje não recebemos por parte desse ano de trabalho.

$\underline{\text { Depois que procuramos ajuda, comecaram as ameacas. }} \underline{O \text { gerente e seus }}$ parentes ficavam espionando quando a gente ligava para o advogado.

Ficamos com medo e fugimos para outra cidade. Foi difícil porque não conhecemos ninguém. A gente vem para trabalhar e acaba assim. ${ }^{97}$ (grifos nossos)

Além dos direitos violados citados nos trechos que fazem referência aos flagrantes de 2011, o relato exposto acima apresenta diversos outros descumprimentos à legislação trabalhista que também merecem aqui ser objeto de observação.

Em primeira análise, é possível verificar a ocorrência de trabalho em horário noturno, que, de acordo com os arts. 73 e 74 da CLT e $7^{\circ}$, inciso IX, da CF, deverá ter remuneração superior à hora diurna em pelo menos $20 \%$, o que evidentemente não era respeitado pelo empregador, uma vez que o horário de ponto registrado pela preposta que gerenciava a facção não refletia a real jornada de trabalho, prática chamada de "horário britânico" que é inválida como prova de registro de ponto, conforme a Súmula 338 do TST.

Ainda, nota-se a transferência do risco do empreendimento ao empregado diante do desconto como hora incompleta da remuneração por não cumprimento de meta - 30 peças em $1 \mathrm{~h}$, o que de pronto afronta o art. $2^{\circ}$ da CLT, bem claro em definir que a assunção de riscos é característica intrínseca à pessoa do empregador.

97 ARANHA, Ana. "A dona ficava com o nosso salário". In: Repórter Brasil. 09/05/2015. Disponível em: $<$ http://reporterbrasil.org.br/2015/05/a_dona_ficava_com_nosso_salario/>.Acesso em 06 out. 2017. 
Também, verifica-se nas frases "gritava com a gente" e "bateu em um funcionário na nossa frente" o uso de coação, seja física ou psicológica, como meio de intimidação do obreiro para garantir que este cumpra as ordens de seu patrão. Além disso, o uso de "faca na cintura" por quem vigiava os trabalhadores nada mais é do que um modo de execução do trabalho análogo ao escravo por equiparação mediante o uso de vigilância ostensiva no local de trabalho, presente no art. $149, \S 1^{\circ}$, inc. II, do CP.

Quanto ao salário, é nítida a sua retensão indevida por fraude, o que é extremamente aviltante ante o caráter falimentar desta parcela, de modo que a detenção dolosa do salário por terceiro se encontra penalizada por alguns dispositivos do nosso ordenamento jurídico, a exemplo do art. $7^{\circ}$, inc. $\mathrm{X}$, da $\mathrm{CF}$ e do art. 168 do $\mathrm{CP}$, este último sobre o tipo penal de apropriação indébita.

Finalmente, cumpre citar a ofensa aos direitos da personalidade dos trabalhadores que laboravam na oficina de costura, como aqueles dispostos no art. $5^{\circ}$, inc. X, da Carta Cidadã, ao passo que "são invioláveis a intimidade, a vida privada, a honra e a imagem das pessoas", sendo importante a ressalva ao capítulo do $\mathrm{CC}$ que trata dos direitos da personalidade como fonte subsidiária ao direito do trabalho.

Diante destes últimos acontecimentos, foi homologado novo TAC em 10.05.2017 para "redefinir as obrigações e responsabilidades da ZARA", o qual prevê, dentre outros compromissos, o pagamento de R\$ 100.000,00 por cada subcontratado encontrado em situação análoga à escrava, bem como o investimento social no montante de $\mathrm{R} \$ 5.000 .000,00$, valendo-se salientar o reforço e aprimoramento de mecanismos de controle da ZARA sob sua rede de contratação. ${ }^{98}$

Frisa-se, na oportunidade, que ambos os TACs foram assinados

\footnotetext{
${ }^{98}$ BRASIL. Termo de Ajuste de Conduta n ${ }^{\circ}$ 21/2017 (Inquérito Civil n. 0000393.2011.02.002/2). Disponível em: $<$ http://docplayer.com.br/54164020-Ic-de-autos-n-2-termo-de-ajuste-de-conduta-nd-1-2017.html>. Acesso em 10 out. 2017.
} 
prevendo a não confissão de culpa pela marca.

Por todo o exposto, em atenção a grande repercussão dos episódios de trabalho análogo ao escravo que foram flagrados dentro de sua cadeia de manufatura, a magazine vem atualmente investindo muitos esforços na promoção de campanhas que atenuem a imagem negativa atrelada à sua marca, tendo, por exemplo, lançado sua primeira coleção sustentável, chamada Join Life ${ }^{99}$, que utiliza materiais reciclados e algodão orgânico na elaboração de suas peças, além do uso de menor consumo de água e energia dentro do seu processo produtivo.

${ }^{99}$ GUADAGNUCCI, Natália. Zara lança primeira coleção sustentável no Brasil. In: L'OFFICIEL. 10/03/2017. Disponível em: < https://www.revistalofficiel.com.br/mode/zara-lanca-primeiracolecao-sustentavel-no-brasil>. Acesso em 02 nov. 2017. 


\section{PARTE VI - A LUTA PELA ERRADICAÇÃO DO TRABALHO ESCRAVO CONTEMPORÂNEO}

\section{Apresentação dos Mecanismos de Combate}

Em 1995, após mais de cem anos da promulgação da Lei Áurea (1888), o governo brasileiro reconheceu perante a comunidade internacional que ainda havia escravidão em seu território, passando a criar, dessa forma, mecanismos de combate ao trabalho escravo contemporâneo. ${ }^{100}$

Dando-se início à luta pela erradicação do trabalho escravo no país, foi fundado o Grupo Especial de Fiscalização Móvel (GEFM) no MT, composto por auditores fiscais do trabalho, delegados e agentes da Polícia Federal, procuradores do MPT e, em determinadas operações, por procuradores da República, do Instituto Brasileiro do Meio Ambiente e dos Recursos Naturais Renováveis (IBAMA) e do Instituto Nacional de Colonização e Reforma Agrária (INCRA). ${ }^{101}$

Durante a atuação do GEFM, os fiscais do trabalho se concentram em coletar evidências, realizar a compilação de relatórios, emitir autorizações de trabalho aos resgatados e providenciar o seu registro no seguro desemprego, enquanto que a Polícia Federal se encarrega de garantir a segurança do grupo móvel, realizar a coleta de provas que possam fundamentar eventual indiciamento criminal, bem como, de prender os criminosos, confiscar armas, fechar o local de trabalho e apreender os bens produzidos irregularmente, tendo, por fim, o MPT a responsabilidade em providenciar uma solução judicial imediata e propor, se possível, TAC à

\footnotetext{
100 ONUBR. Trabalho Escravo. Brasília, abril de 2016. Disponível em: $<$ https://nacoesunidas.org/wp-content/uploads/2016/04/position-paper-trabalho-escravo.pdf $>$. Acesso em 16 set. 2017.

${ }^{101}$ MPT 24a REGIÃO. MPT lembra 20 anos do grupo móvel de combate ao trabalho escravo. Disponível em: <http://www.prt24.mpt.mp.br/informe-se/noticias-do-mpt-ms/345-mpt-lembra-20anos-do-grupo-movel-de-combate-ao-trabalho-escravo>. Acesso em 12 out. 2017.
} 
empresa infratora. ${ }^{102}$

Registra-se que em duas décadas de atuação (1995 - 2015), foram resgatados pelo grupo móvel certa de 47 mil trabalhadores submetidos à superexploração em propriedades rurais e em empresas localizadas nos centros urbanos, a exemplo da Grande São Paulo. ${ }^{103}$

De forma evolutiva, passaram a ser criadas varas do trabalho em áreas de grande incidência de casos de trabalho escravo, a exemplo das varas criadas no sul do Pará, merecendo relevância, também, a criação da Coordenadoria Nacional de Erradicação do Trabalho Escravo (CONAETE), em 2002, pelo MPT. ${ }^{104}$

Além disso, podemos também falar da criação da Comissão Nacional para a Erradicação do Trabalho Escravo (CONATRAE) pelo Decreto sem número, em 2003, com a principal finalidade de buscar-se coordenar e avaliar a implementação das ações previstas no Plano Nacional para a Erradicação do Trabalho Escravo (PNETE). ${ }^{105}$

Os Planos Nacionais para a Erradicação do Trabalho Escravo foram dois, referentes aos anos de 2003 e 2008, que serviram de base para planos internos ${ }^{106}$, tendo sido assinada, em 2009, Declaração Conjunta entre o presidente da República e o diretor-geral da OIT para estabelecer marco de

102 CAMPOS, André (Repórter Brasil); HUIJSTEE, Mariëtte van; Theuws, Martje (SOMO). Da responsabilidade moral à responsabilização jurídica? As condições de escravidão moderna na cadeia global de suprimentos da indústria do vestuário e a necessidade de fortalecer os marcos regulatórios: o caso da Inditex-Zara no Brasil. Amsterdã, mai. 2015. Disponível em $<$ http://reporterbrasil.org.br/wp-content/uploads/2015/05/Reporter-Brasil-web-P.pdf $>$. Acesso em 20 set. 2017.

${ }^{103}$ MPT 24a REGIÃO. MPT lembra 20 anos do grupo móvel de combate ao trabalho escravo. Disponível em: <http://www.prt24.mpt.mp.br/informe-se/noticias-do-mpt-ms/345-mpt-lembra-20anos-do-grupo-movel-de-combate-ao-trabalho-escravo>. Acesso em 12 out. 2017.

${ }^{104}$ BRITO FILHO, José Cláudio Monteiro de. Trabalho Decente: Análise Jurídica da Exploração do Trabalho - Trabalho Escravo e outras Formas de Trabalho Indigno. 4a ed. São Paulo: LTr, 2016.

105 MINISTÉRIO DOS DIREITOS HUMANOS. Combate ao Trabalho Escravo. Disponível: $<$ http://www.sdh.gov.br/assuntos/conatrae/programas/comissao-nacional-para-a-erradicacao-dotrabalho-escravo>. Acesso em 13 out. 2017.

${ }^{106}$ BRITO FILHO, José Cláudio Monteiro de. Trabalho Decente: Análise Jurídica da Exploração do Trabalho - Trabalho Escravo e outras Formas de Trabalho Indigno. $4^{\text {a }}$ ed. São Paulo: LTr, 2016. 
cooperação para o desenvolvimento do Plano Nacional do Trabalho Decente (PNTD) no Brasil. ${ }^{107}$

Outrossim, cumpre aqui elencar demais ações de combate ao trabalho escravo que merecem notoriedade, como:

A Medida Provisória ${ }^{\circ} 74 / 2002$, convertida na Lei 10.608/2002, que alterou a Lei 7.998/90, assegurando o pagamento de segurodesemprego ao trabalhador resgatado em condição análoga a de escravo: ${ }^{108}$

Art. $2^{\circ}$-C O trabalhador que vier a ser identificado como submetido a regime de trabalho forçado ou reduzido a condição análoga à de escravo, em decorrência de ação de fiscalização do Ministério do Trabalho e Emprego, será dessa situação resgatado e terá direito à percepcão de três parcelas de seguro-desemprego no valor de um salário mínimo cada, conforme o disposto no $\S 20$ deste artigo. (Incluído pela Lei ${ }^{\circ} 10.608$, de 20.12.2002)

$\S 10 \mathrm{O}$ trabalhador resgatado nos termos do caput deste artigo será encaminhado, pelo Ministério do Trabalho e Emprego, para qualificação profissional e recolocação no mercado de trabalho, por meio do Sistema Nacional de Emprego - SINE, na forma estabelecida pelo Conselho Deliberativo do Fundo de Amparo ao Trabalhador - CODEFAT. (Incluído pela Lei $\mathrm{n}^{\circ}$ 10.608, de 20.12.2002)

§ 2o Caberá ao CODEFAT, por proposta do Ministro de Estado do Trabalho e Emprego, estabelecer os procedimentos necessários ao recebimento do benefício previsto no caput deste artigo, observados os respectivos limites de comprometimento dos recursos do FAT, ficando vedado ao mesmo trabalhador o recebimento do benefício, em circunstâncias similares, nos doze meses seguintes à percepção da última parcela. (Incluído pela Lei $\mathrm{n}^{\mathrm{o}}$ 10.608, de 20.12.2002) (grifos nossos)

A Emenda Constitucional $n^{\circ} 81 / 2014$, anteriormente nomeada de "PEC do Trabalho Escravo", que acrescentou ao artigo 243 da CF a possibilidade de expropriação de propriedades urbanas e rurais em que for

${ }^{107}$ BRITO FILHO, José Cláudio Monteiro de. Trabalho Decente: Análise Jurídica da Exploração do Trabalho - Trabalho Escravo e outras Formas de Trabalho Indigno. 4a ed. São Paulo: LTr, 2016.

108 COSTA, Flávio Dino de Castro e. O Combate ao Trabalho Forçado no Brasil: Aspectos Jurídicos. Revista do Ministério Público do Trabalho, Brasília, ano XIII, $\mathrm{n}^{\circ}$. 26. São Paulo: Ltr, 2003. p. 86-109. Disponível em: $<$ http://www.anpt.org.br/attachments/article/2720/Revista\%20MPT\%20\%20Edi\%C3\%A7\%C3\%A3o\%2026.pdf>. Acesso em 04 fev. 2017. 
constatado o uso de mão de obra de trabalho escravo: ${ }^{109}$

Art. 243. As propriedades rurais e urbanas de qualquer região do País onde forem localizadas culturas ilegais de plantas psicotrópicas ou a exploração de trabalho escravo na forma da lei serão expropriadas e destinadas à reforma agrária e a programas de habitação popular, sem qualquer indenização ao proprietário e sem prejuízo de outras sanções previstas em lei, observado, no que couber, o disposto no art. $5^{\circ}$. (Redação dada pela Emenda Constitucional n ${ }^{\circ}$ 81, de 2014)

A "Lista Suja", melhor definida como um cadastro que relaciona os empregadores beneficiários da mão de obra análoga à escrava em sua cadeia produtiva, que foi criada em 2013 e se encontra atualmente regulamentada pela Portaria Interministerial $n^{\circ} 4 / 2016$ do MT, a ser mais satisfatoriamente analisada em tópico específico.

A Lei do estadual de São Paulo no $14.946 / 2013$, que visa a punição dos empregadores que superexploram seus trabalhadores através da cassação da eficácia de sua inscrição no cadastro de contribuintes do Imposto sobre Circulação de Mercadorias e Serviços (ICMS), também a ser melhor desenvolvida em seção própria. ${ }^{110}$

E a CPI do Trabalho Escravo de São Paulo, que foi instaurada e presidida pelo Deputado Carlos Bezerra Jr. em 2014, para investigar as recorrentes violações de direitos humanos que ocorrem no setor têxtil da Grande São Paulo. ${ }^{111}$

\subsection{Ações Coordenadas Preventivas e Repressivas}

Quando ocorre o resgate, geralmente pelo GEFM com apoio do MPT

\footnotetext{
109 COSTA, Flávio Dino de Castro e. O Combate ao Trabalho Forçado no Brasil: Aspectos Jurídicos. Revista do Ministério Público do Trabalho, Brasília, ano XIII, n . 26. São Paulo: Ltr, 2003. p. 86-109. Disponível em: $<$ http://www.anpt.org.br/attachments/article/2720/Revista\%20MPT\%20\%20Edi\%C3\%A7\%C3\%A3o\%2026.pdf>. Acesso em 04 fev. 2017.

${ }^{110}$ BRASIL. Ministério Público do Trabalho. Procuradoria Regional do Trabalho da $2^{\text {a }}$ Região. Ação Civil Pública. Réu: M5 Indústria e Comércio Ltda. 2014. Disponível em: $<$ http://reporterbrasil.org.br/documentos/acp-mofficer.pdf $>$. Acesso em 14 jul. 2017

111 SANTINI, Daniel. Em São Paulo, CPI do Trabalho Escravo cria canal para receber denúncias. In: Repórter Brasil. 24/04/2014. Disponível em: <http://reporterbrasil.org.br/2014/04/em-saopaulo-cpi-do-trabalho-escravo-cria-canal-para-receber-denuncias/>. Acesso em 04 out. 2017.
} 
e da Polícia Federal, os trabalhadores imigrantes têm suas carteiras assinadas, seus direitos trabalhistas pagos e são encaminhados para o seu local de origem, se assim desejarem. Os empregadores são autuados pelo MT, sendo a eles imposto o pagamento de multas, além de serem acionados civilmente pelo MPT e criminalmente pelo MPF. ${ }^{112}$

$\mathrm{Na}$ esfera cível, constatada a presença de irregularidades em determinada linha de produção, o MPT busca, principalmente, a responsabilidade dos empresários que se utilizam dos serviços das oficinas clandestinas investigadas por meio da assinatura de TAC, com o objetivo de cessar o ilícito - a exploração de mão de obra de imigrantes em condições degradantes e aliciamento destes trabalhadores - e iniciar a adoção de medidas que regularizem a atividade. ${ }^{113}$

Já na esfera penal, por outro lado, as condenações, quando ocorrem, tendem a ser transformadas em penas alternativas. Nesse sentido, se faz impositivo que seja buscada a responsabilização criminal do tomador de serviços, dos aliciadores de mão de obra ("gatos") e das autoridades administrativas que foram omissas quanto ao seu dever de fiscalização do trabalho em condições indignas. ${ }^{114}$

Tal enfrentamento do trabalho escravo exige ações coordenadas, senão vejamos:

É preciso quem denuncie (sindicatos, ONGs, Igrejas, etc.). Quem fiscalize as condições de trabalho (Ministério do Trabalho) e o tráfego ou transporte de trabalhadores (Polícia Rodoviária). É necessário quem dê garantias aos agentes

\footnotetext{
112 FILGUEIRAS, Vitor Araújo. Trabalho análogo ao escravo e o limite da relação de emprego: natureza e disputa na regulação do estado. In: PRADO, Adonia Antunes; GALVÃ̃O, Edna Maria; FIGUEIRA, Ricardo Rezende (Orgs). A Universidade Discute a Escravidão Contemporânea: Práticas e Reflexões. $1^{\mathrm{a}}$ ed. Rio de Janeiro: Mauad X, 2015. p. 133-156.

113 MELO, Luís Antônio Camargo de. Premissas para um eficaz combate ao trabalho escravo. Revista do Ministério Público do Trabalho, Brasília, ano XIII, n ${ }^{\circ}$ 26. São Paulo: Ltr, 2003. p. 1133. Disponível em: <http://www.anpt.org.br/attachments/article/2720/Revista\%20MPT\%20\%20Edi\%C3\%A7\%C3\%A30\%2026.pdf>. Acesso em 04 fev. 2017.

114 MELO, Luís Antônio Camargo de. Premissas para um Eficaz Combate ao Trabalho Escravo. Revista do Ministério Público do Trabalho, Brasília, ano XIII, n ${ }^{\circ}$ 26. São Paulo: Ltr, 2003. p. 1133. Disponível em: <http://www.anpt.org.br/attachments/article/2720/Revista\%20MPT\%20\%20Edi\%C3\%A7\%C3\%A3o\%2026.pdf>. Acesso em 04 fev. 2017.
} 
das fiscalização trabalhista, às diligências levadas a efeito pelo próprio representante do Ministério Público e exerça a polícia judiciária (Polícia Federal). Quem mova as ações judiciais de responsabilização dos infratores (Ministério Público). E quem julgue tais infratores (Poder Judiciário). Sem informação ou denúncia o Ministério Público do Trabalho não agirá. Sem as Policias não será possível realizar as fiscalizações com segurança física e moral dos auditores. Sem os elementos colhidos pela físcalização e pelos policiais, o Ministério Público não terá condições de instruir seus inquéritos civis e suas ações judiciais, que, se não forem movidas, obviamente, não serão julgadas, e a impunidade reinará. Devem ser integrados nessa corrente, ainda, as Polícias estaduais e os Ministérios Públicos dos Estados, seja para auxiliarem os demais, seja para agirem residualmente no que sobejar das incumbências daqueles. ${ }^{115}$

Contudo, somente a implementação de ações coordenadas repressivas não são suficientes para erradicar o trabalho escravo moderno, sendo necessária a adoção de mecanismos que procurem extinguir o problema na sua origem, a exemplo da instituição de políticas públicas que visem combater a miséria e fomentar o emprego nas regiões exportadoras de escravos, ou seja, capazes de desestimular a imigração em busca de melhores oportunidades, vez que os trabalhadores resgatados tendem a retornar ao status quo caso não encontrem trabalho que lhes ofereça condições dignas de subsistência em sua região de origem. ${ }^{116}$

Nesse liame, indispensável também se faz a promoção de campanhas de esclarecimento de trabalhadores imigrantes quanto aos seus direitos trabalhistas e a regularização de sua condição - muitas vezes - ilegal no país.

Por fim, é fundamental que as autoridades adotem medidas póslibertação passíveis de garantir ao trabalhador regatado uma moradia provisória, alimentação, cuidados médicos, programas de desenvolvimento

\footnotetext{
115 SOARES, Evanna. Meios coadjuvantes de combate ao trabalho escravo pelo Ministério Público do Trabalho. Revista do Ministério Público do Trabalho, Brasília, ano XIII, $\mathrm{n}^{\circ}$. 26. São Paulo: Ltr, 2003. p. 34-46. Disponível em:

$<$ http://www.anpt.org.br/attachments/article/2720/Revista\%20MPT\%20\%20Edi\%C3\%A7\%C3\%A3o\%2026.pdf>. Acesso em 04 fev. 2017.p. 39.

116 SOARES, Evanna. Meios coadjuvantes de combate ao trabalho escravo pelo Ministério Público do Trabalho. Revista do Ministério Público do Trabalho, Brasília, ano XIII, n . 26. São Paulo: Ltr, 2003. p. 34-46. Disponível em:

$<$ http://www.anpt.org.br/attachments/article/2720/Revista\%20MPT\%20-

\%20Edi\%C3\%A7\%C3\%A3o\%2026.pdf>. Acesso em 04 fev. 2017.
} 
profisssional e condições para o seu retorno à cidade natal. ${ }^{117}$

\subsection{A “Lista Suja” do Trabalho Escravo}

Trata-se de mecanismo combativo de referência mundial que busca, após decisão administrativa irrecorrível relativa aos autos de infração lavrados no momento do flagrante, divulgar o nome dos empregadores que submetem aqueles que lhes prestam serviços a condições subumanas, servindo como ferramenta de transparência do Poder Público ante seu dever em fiscalizar e garantir efetividade dos direitos trabalhistas. ${ }^{118}$

Como um de seus principais efeitos, além da exposição diante da sociedade do empregador como agente que compactua com a prática da escravidão contemporânea, podemos citar também a negativa de acesso a financiamentos em bancos públicos, como o Banco Nacional de Desenvolvimento Econômico e Social (BNDES) e o Banco do Brasil, que assinaram o Pacto Nacional pela Erradicação do Trabalho Escravo. Sublinha-se, ainda, que bancos privados também se utilizam das informações disponíveis na "Lista Suja" para avaliarem o risco no fornecimento de crédito às empresas cadastradas.

A título de ilustração, convém a menção dos seguintes dispositivos da Portaria Interministerial $n^{\circ}$ 4/2016:

Art. $1^{\circ}$ Estabelecer, no âmbito do Ministério do Trabalho e Previdência Social (MTPS), Cadastro de Empregadores que tenham submetido trabalhadores a condições análogas à de escravo, bem como dispor sobre as regras que lhes são aplicáveis.

Art. $2^{\circ} \mathrm{O}$ Cadastro de Empregadores será divulgado no sítio eletrônico oficial do Ministério do Trabalho e Previdência Social (MTPS), contendo a relacão

\footnotetext{
117 SANTOS, Ronaldo Lima dos. A escravidão por dívidas nas relações de trabalho no Brasil contemporâneo. Revista do Ministério Público do Trabalho, Brasília, ano XIII, n . 26. São Paulo: Ltr, 2003. p. 47-66. Disponível em: $<$ http://www.anpt.org.br/attachments/article/2720/Revista\%20MPT\%20\%20Edi\%C3\%A7\%C3\%A3o\%2026.pdf>. Acesso em 04 fev. 2017.

118 SAKAMOTO, Leonardo. Justiça determina que governo volte a divulgar "lista suja" da escravidão. In: Repórter Brasil. 19/12/2016. Disponível em: $<$ http://reporterbrasil.org.br/2016/12/justica-determina-que-governo-volte-a-divulgar-lista-suja-daescravidao/>.Acesso em 04 out. 2017.
} 
de pessoas físicas ou jurídicas autuadas em acão fiscal que tenha identificado trabalhadores submetidos à condições análogas à de escravo.

$\S 1^{\circ} \mathrm{A}$ inclusão do empregador somente ocorrerá após a prolacão de decisão administrativa irrecorrível de procedência do auto de infração lavrado na ação fiscal em razão da constatação de exploração de trabalho em condições análogas à de escravo.

Art. $3^{\circ} \mathrm{O}$ nome do empregador permanecerá divulgado no Cadastro por um período de 2 (dois) anos, durante o qual a Inspeção do Trabalho realizará monitoramento a fim de verificar a regularidade das condições de trabalho.

Parágrafo único. Verificada, no curso do período previsto no caput deste artigo, reincidência na identificação de trabalhadores submetidos à condições análogas à de escravo, com a prolação de decisão administrativa irrecorrível de procedência do novo auto de infração lavrado, o empregador permanecerá no Cadastro por mais 2 (dois) anos, contados a partir de sua reinclusão.

Art. $5^{\circ}$ A União poderá, com a necessária participação e anuência da Secretaria de Inspeção do Trabalho do Ministério do Trabalho e Previdência Social, e observada a imprescindível autorização, participação e representação da Advocacia-Geral da União para a prática do ato, celebrar Termo de Ajustamento de Conduta (TAC) ou acordo judicial com o administrado sujeito a constar no Cadastro de Empregadores, com objetivo de reparação dos danos causados, saneamento das irregularidades e adoção de medidas preventivas e promocionais para evitar a futura ocorrência de novos casos de trabalho em condições análogas à de escravo, tanto no âmbito de atuação do administrado quanto no mercado de trabalho em geral.

$\S 3^{\circ} \mathrm{O}$ empregador que celebrar Termo de Ajustamento de Conduta (TAC) ou acordo judicial na forma disciplinada neste artigo não integrará a relação disciplinada no art. $2^{\circ}$ desta Portaria, mas uma segunda relação, localizada topicamente logo abaixo da primeira, devendo ambas integrarem o mesmo documento e meio de divulgacão.

Art. 10. Os empregadores que celebrarem Termo de Ajustamento de Conduta (TAC) ou acordo judicial nos termos desta Portaria permanecerão na relação prevista no $\S 3^{\circ}$ do art. $5^{\circ}$ pelo prazo máximo de 2 (dois) anos, contados de sua inclusão, e poderão requerer sua exclusão após 1 (um) ano. (grifos nossos)

Conforme o exposto, comprovada a infração perpetrada pelo empregador, este deverá permanecer no cadastro pelo período de dois anos. Caso seja assinado TAC ou acordo judicial com o governo federal, em que o tomador de serviços autuado se comprometa a adotar uma série de condicionantes, poderá o mesmo somente constar em uma espécie de “área de observação" do cadastro, em que se encontram designadas as empresas flagradas que estão empenhando esforços na regularização do seu negócio, sendo excluídas se em um ano for constatado o cumprimento das exigências firmadas no termo.

Ocorre que, mesmo verificada a regularização do empreendimento 
dentro do citado período, temos recente decisão da $6^{\mathrm{a}}$ Turma do TST (Processo 1330-50.2013.5.10.0009), que foi unânime quanto à necessidade de cumprimento do prazo de dois anos sem ser constatada a reincidência para que o empregador que firmou TAC possa ser finalmente excluído da lista. ${ }^{119}$

Não por acaso, tal instrumento é alvo de diversas críticas, a exemplo de ser considerada como suficiente a decisão em âmbito administrativo para a inclusão do autuado no cadastro, sem se exigir que o caso seja resolvido em sede judicial, o que para muitos passa a ferir o art. $5^{\circ}$, inc. $\mathrm{XXXV}$, da nossa Constituição. ${ }^{120}$

Os argumentos supracitados, somados a outras insatisfações, deram ensejo, em 2014, à suspensão do cadastro pelo STF em sede de liminar concedida à Associação Brasileira de Incorporadoras Imobiliárias (Abrainc) na Ação Direta de Inconstitucionalidade (ADI) n 5.209 que, em 2016, foi cassada pela Ministra Cármen Lúcia, sob o entendimento de que os mecanismos que regulamentavam a presente lista foram aprimorados na Portaria Interministerial publicada no mesmo ano. ${ }^{121}$

Sem embargo às críticas sofridas pelo instituto, neste trabalho, defenderemos a acertada existência e divulgação da "Lista Suja", vez que o Estado possui o poder-dever de criar mecanismos capazes de coibir a exploração do trabalho em condições aviltantes, além de ser certo que para tais empregadores estarem cadastrados na presente lista, foram constatadas graves infrações no momento do flagrante pelos ficais do trabalho que os

\footnotetext{
119 REVISTA CONSULTOR JURÍDICO. Empresa deve ficar dois anos na "lista suja" mesmo se regularizada, diz TST. 21/09/2017. Disponível em: <https://www.conjur.com.br/2017-set21/empresa-ficar-dois-anos-lista-suja-mesmo-regularizada>. Acesso em 04 out. 2017.

${ }^{120}$ MATSUMOTO, Jorge Gonzaga; DUARTE, Vinicius Franco. Regras da "lista suja" do trabalho escravo necessitam de uma faxina. In: Revista Consultor Jurídico. 27/01/2017. Disponível em: $<$ https://www.conjur.com.br/2017-jan-27/regras-lista-suja-trabalho-escravo-necessitam-faxina $>$. Acesso em 05 out. 2017.

121 SAKAMOTO, Leonardo. Justiça determina que governo volte a divulgar "lista suja" da escravidão. In: Repórter Brasil. 19/12/2016. Disponível em: $<$ http://reporterbrasil.org.br/2016/12/justica-determina-que-governo-volte-a-divulgar-lista-suja-daescravidao/>.Acesso em 04 out. 2017.
} 
levaram a lavrar autos de infração motivados pela identificação de trabalho análogo ao escravo no empreendimento.

Nesse sentido, convém mencionar, em uma última exposição, as seguintes considerações do Procurador do Trabalho Tiago Cavalcanti, que atualmente assume posição de destaque na Coordenadoria Nacional de Erradicação do Trabalho Escravo (CONAETE) do MPT:

A obrigação do Ministério do Trabalho em divulgar os nomes dos empregadores que exploram o trabalho escravo decorre de compromissos assumidos pela República Federativa do Brasil em âmbito internacional, os quais impedem retrocessos nos passos já trilhados em prol da erradicação da escravidão contemporânea. ${ }^{122}$

É uma política de Estado que independe de valores ideológicos e partidários, não podendo haver solução de continuidade. Além do mais, a Lei de Acesso à Informação determina expressamente que a Administração dê ampla divulgação ao resultado de inspeções e auditorias, de modo que a negligência do Ministério do Trabalho representa uma ilegalidade em si. ${ }^{123}$ (grifos nossos)

\subsection{A Lei Estadual n 14.946/2013 - São Paulo}

A Lei Estadual no 14.946/2013 de São Paulo, de autoria do Deputado Carlos Bezerra Junior, foi criada em resposta aos inúmeros casos de flagrante de trabalho escravo identificados no setor têxtil paulista, com o objetivo de determinar a cassação da eficácia da inscrição no ICMS dos estabelecimentos que comercializam produtos em cuja fabricação tenha havido, em qualquer de suas etapas de industrialização, condutas que configurem redução de pessoa à condição análoga a de escravo ${ }^{124}$. A título de ilustração, segue dispositivo que sanciona a conduta:

\footnotetext{
122 SAKAMOTO, Leonardo. Justiça determina que governo volte a divulgar "lista suja" da escravidão. In: Repórter Brasil. 19/12/2016. Disponível em: $<$ http://reporterbrasil.org.br/2016/12/justica-determina-que-governo-volte-a-divulgar-lista-suja-daescravidao/>.Acesso em 04 out. 2017.

123 SAKAMOTO, Leonardo. Justiça determina que governo volte a divulgar "lista suja" da escravidão. In: Repórter Brasil. 19/12/2016. Disponível em: $<$ http://reporterbrasil.org.br/2016/12/justica-determina-que-governo-volte-a-divulgar-lista-suja-daescravidao/>.Acesso em 04 out. 2017.

${ }^{124}$ BRASIL. Ministério Público do Trabalho. Procuradoria Regional do Trabalho da $2^{\mathrm{a}}$ Região. Ação Civil Pública. Réu: M5 Indústria e Comércio Ltda. 2014. Disponível em: $<$ http://reporterbrasil.org.br/documentos/acp-mofficer.pdf $>$. Acesso em 14 jul. 2017
} 
Artigo $1^{\circ}$ - Além das penas previstas na legislação própria, será cassada a eficácia da inscrição no cadastro de contribuintes do imposto sobre operações relativas à circulação de mercadorias e sobre prestações de serviços de transporte interestadual, intermunicipal e de comunicação (ICMS) dos estabelecimentos que comercializarem produtos em cuja fabricação tenha havido, em qualquer de suas etapas de industrializacão, condutas que configurem redução de pessoa a condição análoga à de escravo. (grifos nossos)

A referida lei foi regulamentada por meio do Decreto 59.170/2013, cujo teor trata do procedimento administrativo para cassação do ICMS no âmbito da Secretaria da Fazenda do Estado de São Paulo, e pela Recomendação $\mathrm{n}^{\circ}$. 1/2014 da Comissão Estadual para Erradicação do Trabalho Escravo (COETRAE), que busca orientar a aplicação das normas. ${ }^{125}$

Frisa-se que o artigo $4^{\circ}$ da lei estadual esclarece que ao ser realizada a cassação da inscrição no cadastro de contribuintes do ICMS, o empregador, seja pessoa física ou jurídica, estará impedido de atuar no mesmo ramo de atividade, mesmo que em outro estabelecimento diferente daquele em que houve o flagrante, prevalecendo tal restrição pelo prazo de 10 anos contados da data da cassação, senão vejamos:

Artigo $4^{\circ}$ - A cassação da eficácia da inscrição do cadastro de contribuintes do ICMS, prevista no artigo $1^{\circ}$, implicará aos sócios, pessoas físicas ou jurídicas, em conjunto ou separadamente, do estabelecimento penalizado:

I - o impedimento de exercerem o mesmo ramo de atividade, mesmo que em estabelecimento distinto daquele;

II - a proibição de entrarem com pedido de inscrição de nova empresa, no mesmo ramo de atividade.

$\S 1^{\mathrm{o}}$ - As restrições previstas nos incisos prevalecerão pelo prazo de 10 (dez) anos, contados da data de cassação.

$\overline{\S 2^{\circ}}$ - Caso o contribuinte seja optante pelo Regime Especial Unificado de Arrecadação de Tributos e Contribuições (Simples Nacional), instituído pela Lei Complementar federal $n^{\circ} 123$, de 14 de dezembro de 2006, a cassação da eficácia da sua inscrição no cadastro de contribuintes do ICMS, prevista no artigo $1^{\circ}$, implicará cumulativamente:

1 - a perda do direito ao recebimento de créditos do Tesouro do Estado, instituído pelo Programa de Estímulo à Cidadania Fiscal do Estado de São Paulo, de que trata a Lei no 12.685, de 28 de agosto de 2007;

125 BRASIL. Ministério Público do Trabalho. Procuradoria Regional do Trabalho da $2^{\mathrm{a}}$ Região. Ação Civil Pública. Réu: M5 Indústria e Comércio Ltda. 2014. Disponível em: $<$ http://reporterbrasil.org.br/documentos/acp-mofficer.pdf $>$. Acesso em 14 jul. 2017 
2 - o cancelamento dos créditos já calculados ou liberados, referentes ao Programa de Estímulo à Cidadania Fiscal do Estado de São Paulo, citado no item 1 , independentemente do prazo previsto no $\S 2^{\circ}$ do artigo $5^{\circ}$ da Lei $n^{\circ} 12.685$, de 28 de agosto de 2007. (grifos nossos)

Ademais, cumpre salientar que o governador Geraldo Alckimin, responsável por sancionar o dispositivo, reconheceu a grande incidência de trabalhadores encontrados em situação análoga à escrava em facções clandestinas no estado de São Paulo, tendo oportunamente declarado:

São Paulo não abriga cativeiros. São Paulo abriga fábricas. Que não existem para gerar milhões de reais, mas para gerar empregos. O trabalho serve para engrandecer o homem, não para aviltá-lo. ${ }^{126}$

Resultará numa concorrência mais leal, e será uma garantia ao mundo de que os produtos fabricados em São Paulo são livres de trabalho escravo. ${ }^{127}$

Diante dos fatos narrados, nota-se que a presente lei nada mais é do que o resultado da insatisfação geral da comunidade paulista pelas práticas escusas de mercado, podendo ser entendida como um aprimoramento da "lista suja", que dispõe de uma resposta mais radical aos empresários que se beneficiam de alguma forma da superexploração do trabalhador: a proibição total do exercício da atividade econômica têxtil.

\footnotetext{
${ }^{126}$ OJEDA, Igor. Alckmin sanciona lei que fecha empresa que usar trabalho escravo em São Paulo. In: Repórter Brasil. 23/01/2013. Disponível em: <http://reporterbrasil.org.br/2013/01/alckminsanciona-lei-que-fecha-empresa-que-usa-trabalho-escravo/>. Acesso em 24 out. 2017.

${ }^{127}$ OJEDA, Igor. Alckmin sanciona lei que fecha empresa que usar trabalho escravo em São Paulo. In: Repórter Brasil. 23/01/2013. Disponível em: <http://reporterbrasil.org.br/2013/01/alckminsanciona-lei-que-fecha-empresa-que-usa-trabalho-escravo/>. Acesso em 24 out. 2017.
} 


\section{PARTE VII: A SOMBRA DO RETROCESSO - PORTARIA MTB 1.129/2017}

Ao final da elaboração deste trabalho, foi publicada no Diário Oficial da União, em 16.10.2017, a Portaria MTB 1.129/2017, assinada pelo Ministro do Trabalho, Ronaldo Nogueira, dias após a exoneração do chefe da Divisão de Fiscalização para Erradicação do Trabalho Escravo (Detrae) do MT, André Roston, em atendimento a antigas reivindicações da bancada ruralista. ${ }^{128}$

Em síntese, o ato objetiva delimitar - restringir - o conceito de trabalho análogo ao escravo para fins de concessão do seguro desemprego aos trabalhadores resgatados, bem como alterar - engessar - o processo de fiscalização e de inclusão de empresas na "lista suja" do trabalho escravo.

Nesse liame, vejamos aqui as motivações da Portaria em referência e, consequentemente, a nova definição de trabalho análogo ao escravo por ela apresentada:

Art. $1^{\circ}$ Para fins de concessão de beneficio de seguro-desemprego ao trabalhador que vier a ser identificado como submetido a regime de trabalho forçado ou reduzido a condição análoga à de escravo, nos termos da Portaria MTE $\mathrm{n}^{\circ} 1.153$, de 13 de outubro de 2003, em decorrência de fiscalização do Ministério do Trabalho, bem como para inclusão do nome de empregadores no Cadastro de Empregadores que tenham submetido trabalhadores à condição análoga à de escravo, estabelecido pela PI MTPS/MMIRDH no 4, de 11.05.2016, considerarse-á:

I - trabalho forçado: aquele exercido sem o consentimento por parte do trabalhador e que lhe retire a possibilidade de expressar sua vontade;

II - jornada exaustiva: a submissão do trabalhador, contra a sua vontade e com privação do direito de ir e vir, a trabalho fora dos ditames legais aplicáveis a sua categoria;

III - condicão degradante: caracterizada por atos comissivos de violação dos direitos fundamentais da pessoa do trabalhador, consubstanciados no cerceamento da liberdade de ir e vir, seja por meios morais ou físicos, e que

${ }^{128}$ RBA. Temer faz agrado a bancada ruralista e altera conceitos de 'trabalho escravo'. In: Rede Brasil Atual. 16/10/2017. Disponível em: $<$ http://www.redebrasilatual.com.br/cidadania/2017/10/temer-faz-agrado-a-bancada-ruralista-ealtera-conceitos-de-trabalho-escravo>. Acesso em 21 out. 2017. 
impliquem na privação da sua dignidade;

IV - condição análoga à de escravo:

a) a submissão do trabalhador a trabalho exigido sob ameaça de punição, $\underline{\text { com }}$ uso de coação, realizado de maneira involuntária;

b) o cerceamento do uso de qualquer meio de transporte por parte do trabalhador, com o fim de retê-lo no local de trabalho em razão de dívida contraída com o empregador ou preposto, caracterizando isolamento geográfico; c) a manutenção de segurança armada com o fim de reter o trabalhador no local de trabalho em razão de dívida contraída com o empregador ou preposto; d) a retenção de documentação pessoal do trabalhador, com o fim de reter o trabalhador no local de trabalho; (grifos nossos)

Dizemos "nova definição" pois, mais que restringir, a Portaria de fato alterou substancialmente a conceituação da superexploração do trabalho.

As especificações acima grifadas no trecho do ato em análise passaram a determinar que o trabalho análogo ao escravo só poderia ser constatado quando identificada a coação direta contra a liberdade de ir e vir do trabalhador, bem como, quando, cumulativamente, fosse verificada a sua ausência de consentimento, de modo que tais elementos seriam ainda condicionantes para a caracterização dos modos de execução de "condições degradantes" e "jornadas exaustivas".

Por conseguinte, é possível dizer que tal instrumento desconstrói a noção moderna de trabalho análogo ao escravo trazida pela reformulação do art. 149 do CP por meio da Lei 10.803/2003, na medida em que retoma como núcleo de direitos violados o direito de ir e vir do trabalhador e a falta de seu consentimento para caracterizar a superexploração, o que não é capaz de abarcar as formas contemporâneas de escravidão que, por serem mais discretas, acabam se centrando na violação da dignidade humana do indivíduo - e a todo o arcabouço de direitos fundamentais que nela se incluem, a exemplo da liberdade de livre locomoção - na ocasião da prestação de serviços, independentemente, frisa-se, de seu consentimento e privação direta de liberdade. 
Não que a ausência de consentimento e a privação de liberdade sejam irrelevantes, contudo, certo é que não mais são os únicos elementos para a caracterização da conduta conforme o $\mathrm{CP}$, a não ser que sejam objeto de uma interpretação ampliativa sobre o que é realmente ter liberdade, que transpassa a noção de cárcere privado, e o que de fato se entende por ausência de consentimento, a partir de uma abordagem extensiva dos vícios de consentimento que anulam a vontade do sujeito trabalhador, aí sim seria possível uma interpretação harmônica entre a Portaria, o diploma penal brasileiro e as leis internacionais sobre o tema.

De maneira mais esclarecedora, se $\mathrm{o}$ ato em análise considerasse $\mathrm{o}$ constrangimento econômico sofrido por aqueles que se submetem a condições de trabalho análogas à escrava como uma forma de consentimento viciado, ou seja, "involuntária", um tipo de "corrente invisível" que prende o trabalhador ao local de trabalho, que lhe viola ante a ausência de instrução e de condições financeiras que the permitam a sua sobrevivência e de sua família fora dele, podemos também dizer que tal cenário nada mais mostra do que um real cerceamento da liberdade do trabalhador, vez que este acaba tendo que optar entre a superexploração ou a fome, a ausência de moradia e a absoluta falta de dinheiro.

Considerando que não serão tais conceitos, como a liberdade e a coação, interpretados da maneira extensiva sugerida acima, resta evidente que a nova Portaria busca tão somente diminuir as hipóteses em que se pode constatar a existência do trabalho escravo moderno.

Destaca-se que o trabalho escravo encontrado no séc. 21 não se atém a requisitos tão ultrapassados como os anteriormente relatados, se expressando, na maioria das vezes, de forma mais velada, na violação persistente de direitos básicos do trabalhador, que analisados em conjunto demonstram a exposição contínua do indivíduo a condições degradantes ou a jornadas exaustivas durante a sua prestação de serviço. 
Não por acaso o STF tem consolidado entendimento de que na escravidão moderna não é necessária a coação direta contra a liberdade de ir e vir, senão vejamos:

EMENTA: PENAL. PROCESSUAL PENAL. DENÚNCIA. CRIMES DE REDUÇÃO A CONDIÇÃO ANÁLOGA À DE ESCRAVO E DE ALICIAMENTO DE TRABALHADORES. DESNECESSIDADE DE VIOLÊNCIA FÍSICA PARA A OCORRÊNCIA DO DELITO. PARA A CARACTERIZAČ̃̃O DO DELITO BASTA A REITERADA OFENSA \begin{tabular}{lllll}
\hline$A O S$ & DIREITOS & FUNDAMENTAIS & DO & TRABALHADOR,
\end{tabular} VULNERANDO SUA DIGNIDADE COMO SER HUMANO. PRESCRIÇÃO QUANTO AO DELITO DE FRUSTRAÇÃO DE DIREITO TRABALHISTA. DENUNCIADO COM IDADE SUPERIOR A SETENTA ANOS. RECEBIMENTO PARCIAL DA DENÚNCIA.

I - A inicial acusatória contemplou a qualificação do acusado, a classificação do crime e o rol de testemunhas, apresentou informações essenciais sobre a prática das condutas, preenchendo os requisitos do art. 41 do CPP.

II - Prescrição da pretensão punitiva estatal em relação ao delito de frustração de direito trabalhista, considerando a pena máxima cominada ao tipo penal (dois anos de detenção) e o fato de o prazo do art. 109, V, do Código Penalnecessitar ser reduzido à metade (art. $115 \mathrm{do} \mathrm{CP}$ ); a prescrição é, inclusive, anterior à remessa dos autos a esta Corte.

III - A jurisprudência do Supremo Tribunal Federal entende ser desnecessário haver violência física para a configuração do delito de redução à condição análoga à de escravo. É preciso apenas a coisificacão do trabalhador, com a reiterada ofensa a direitos fundamentais, vulnerando a sua dignidade como ser humano (Inq 3.412, Redatora p/ Acórdão: Min. Rosa Weber, Tribunal Pleno, DJe 12/11/2012).

IV - Presentes os indícios de materialidade e autoria, a denúncia foi parcialmente recebida para os crimes de redução a condição análoga à de escravo e de aliciamento de trabalhadores de um local para outro do território nacional, tipificados nos arts. 149 e 207, $\S 1^{\circ}$, ambos do Código Penal.

(STF - INQ 3564 / MG, Relator: Min. RICARDO LEWANDOWSKI, Data de Julgamento: 19/08/2014, Segunda Turma, Data de Publicação: 17/10/2014) (grifos nossos)

Convém salientar, ainda, ser evidente que o ato recentemente publicado está em flagrante conflito com a conceituação de trabalho análogo ao escravo defendido pela OIT. Nas palavras da Coordenadora do Programa de Combate ao Trabalho Escravo da OIT no país, temos que "O Brasil, a partir de hoje, deixa de ser [a] referência no combate à escravidão 
que estava sendo na comunidade internacional" $[\mathrm{sic}]^{129}$.

Ademais, a nova norma também busca enfraquecer os mecanismos de enfrentamento do trabalho escravo no país, criando diversos entraves burocráticos para que o processo administrativo que apura o flagrante seja recebido pelo órgão julgador competente, a exemplo da exigência de lavratura de Boletim de Ocorrência pela autoridade policial que acompanhou o auditor fiscal durante o resgate e da produção de relatório fotográfico assinado pelo grupo de fiscalização que identifique os envolvidos.

Também, sublinham-se as novas limitações impostas ao instrumento da "lista suja" que a transformam em uma decisão política ignorando sua característica técnica, ao passo que tal relação de empregadores que se beneficiam da superexploração só passará a ser divulgada duas vezes ao ano mediante expressa determinação do Ministro do Trabalho, o que anteriormente ocorria "a qualquer tempo" pela área técnica da Detrae ${ }^{130}$, conforme disciplinado na Portaria MTPS/MMIRDH nº 4 de 11/05/2016.

Não somente, o ato igualmente distorce o TAC previsto na resolução anterior, (1) revogando-se a presença do empregador infrator em uma segunda relação da "lista suja" após a assinatura do termo, além de (2) retirar diversas condições - antes previstas para a assinatura do acordo - que beneficiariam os trabalhadores e (3) deixar de impedir a celebração de novo acordo se constatada a reincidência do crime, dentre outras ilegalidades.

Finalmente, cumpre dizer que a citada Portaria vai de encontro à

${ }^{129}$ PRESSE, Francine. OIT expressa preocupação por decreto sobre trabalho escravo no Brasil. In: G1. 16/10/2017. Disponível em: $<$ https:/www.google.com.br/url? sa=t\&rct=j\&q=\&esrc=s\&source=web\&cd=1\&cad=rja $\&$ uact $=8 \&$ ved=0ahUKEwj376-B-

jWAhXBUZAKHZ_gC_UQqOcBCCYwAA\&url=https\%3A\%2F\%2Fg1.globo.com\%2Feconomi a\%2Fnoticia\%2Foit-expressa-preocupacao-por-decreto-sobre-trabalho-escravo-nobrasil.ghtml\&usg=AOvVaw2MlqOHPVBM2r-BtK5WWjZl>. Acesso em 21 out. 2017.

130 CASADO, Letícia. Ministra do STF concede liminar que suspende portaria do trabalho escravo. In: Folha de São Paulo. 24/10/2017. Disponível em: $<$ http://www1.folha.uol.com.br/mercado/2017/10/1929697-ministra-do-stf-concede-liminar-quesuspende-portaria-do-trabalho-escravo.shtml>. Acesso em 26 out. 2017. 
vedação ao retrocesso da legislação que trata de mecanismos de erradicação do trabalho análogo ao escravo e do tráfico de pessoas imposta pela sentença (2016) da Corte Interamericana de Direitos Humanos no caso Trabalhadores da Fazenda Brasil Verde Vs. Brasil, em que o Brasil foi o primeiro país condenado pela OEA na matéria. ${ }^{131}$

Por conseguinte, diante da flagrante violação aos direitos humanos e do evidente retrocesso trazido pela Portaria, o partido político Rede Sustentabilidade propôs a Arguição de Descumprimento de Preceito Fundamental (ADPF) n. ${ }^{\circ} 489$, a qual teve seu pedido de liminar deferido pela Ministra Rosa Weber em 23.10.2017, ficando o ato suspenso até decisão definitiva de mérito sob a égide dos seguintes fundamentos elencados pela Ministra:

(...) a Portaria do Ministério do Trabalho $\mathrm{n}^{0}$ 1.129/2017 ora adota conceitos tecnicamente frágeis, ora impõe a concatenacão de hipóteses quando, à luz do ordenamento jurídico vigente, a presenca de cada uma delas já seria suficiente. É o que ocorre, por exemplo, com o conceito de trabalho forçado, nela definido não apenas como "aquele exercido sem o consentimento por parte do trabalhador" (opção linguística ambígua e que, por si só se afasta dos parâmetros internacionais e jurisprudenciais), como exige que essa condição seja qualificada pela supressão da "possibilidade de expressar sua vontade", o que é, igualmente ambíguo.

Ao atribuir, à expressão jornada exaustiva, significado afastado de qualquer possibilidade semântica a ela assimilável, porque sequer tangencia as ideias de exaustão física ou mental, de jornada excessiva em extensão ou intensidade, a Portaria opera verdadeiro esvaziamento do conceito. Além disso exige, para a sua configuração, a concatenação com hipótese de "privação do direito de ir e vir", com o qual não se confunde.

A caracterização do conceito de condição degradante fica, igualmente, condicionada à sua concatenação com a figura diversa do "cerceamento da liberdade de ir e vir", com a qual também não se confunde.

(..)

(...) a exigência de ato prévio do Ministro do Trabalho para inclusão do empregador na "lista suja" do trabalho escravo, bem como para a divulgação dessa lista, como prescrevem o art. $3^{\circ}, \S 3^{\circ}$, e o art. $4^{\circ}, \S 1^{\circ}$, da Portaria $n^{\circ}$ $1.129 / 2017$, são medidas administrativas que limitam e enfraquecem as ações

131 VILLELA, Flávia. Corte Interamericana de Direitos Humanos condena Brasil por trabalho escravo. In: Agência Brasil. 16/12/2016. Disponível em: <http://agenciabrasil.ebc.com.br/direitoshumanos/noticia/2016-12/corte-interamericana-de-direitos-humanos-condena-brasil-por>. Acesso em 26 out. 2017. 
de fiscalização, ao contrário de promoverem a diligência necessária para a adequada e efetiva fiscalização. Ainda constituem medidas que condicionam a eficácia de uma decisão administrativa a uma vontade individual de Ministro de Estado, que tem notório viés político. Lógica que inverte a postura técnica pela postura política em matéria de conteúdo técnicojurídico.

$(\ldots)$

Vale ressaltar que, a persistir a produção de efeitos do ato normativo atacado, o Estado brasileiro não apenas se expõe à responsabilização jurídica no plano internacional, como pode vir a ser prejudicado nas suas relações econômicas internacionais, inclusive no âmbito do Mercosul, por traduzir, a utilização de mão-de-obra escrava, forma de concorrência desleal.

(STF - MC ADPF: 489 DF - DISTRITO FEDERAL 0012506-26.2017.1.00.0000, Relator: Min. ROSA WEBER, Data de Julgamento: 23/10/2017, Data de Publicação: DJe-245 26/10/2017) - (grifos nossos)

Em face ao que fora acima relacionado, resta demonstrado que os avanços até agora conquistados pelo país em matéria de erradicação ao trabalho análogo ao escravo se encontram ameaçados por interesses políticos que dialogam com os interesses do capital desregulado, cabendo à sociedade brasileira perseguir os direitos daqueles que não têm voz - os trabalhadores superexplorados - perante as autoridades que não compactuam com este retrocesso, a exemplo do que foi feito a partir da mencionada ação ajuizada pelo partido Rede ao Supremo Tribunal Federal. 


\section{CONCLUSÃO}

O trabalho monográfico apresentado buscou demonstrar o quanto a lógica de mercado fast fashion adotada por muitas marcas da Indústria da Moda se encontra invertida em matéria de direitos humanos, sendo perceptível o uso de artifícios vários para fraudar e precarizar as relações trabalhistas que costuram a rede de contratações sucessivas e indiscriminadas.

Nota-se ser recorrente o proveito pelas grifes do desespero. $\mathrm{O}$ desespero é o que vem alimentando o ciclo do trabalho análogo ao escravo contemporâneo no interior do setor têxtil, fazendo com que o trabalhador não se prenda a critérios dignos para conseguir um emprego. $\mathrm{O}$ uso de mão de obra descartável pela simples intermediação, em que se atribui à força de trabalho humano valor depreciativo, é verificado em cada oficina clandestina escondida no asfalto dos grandes centros urbanos brasileiros.

Sob essa perspectiva, foi possível ao longo do presente estudo inferir que o ciclo de trabalho escravo moderno se sustenta a partir de quatro fatores básicos: (1) a falta de alternativas do trabalhador pobre e imigrante que, ante a ausência de políticas públicas que o fixem no local de origem ou que lhe permitem obter um ofício digno, não vê outra forma de garantir sua subsistência e de sua família sem se expor ao mercado de trabalho irregular, onde sua hipervulnerabilidade - de origem econômica, linguística e educacional - é veladamente superexplorada; (2) o fomento pela prática reiterada de dumping social, em que as grandes magazines, ao baixarem o preço de seus produtos por conta da sonegação de direitos trabalhistas, quase que impõem às demais empresas - que se recusam a perder a competitividade nas vendas - a compactuarem com os métodos escusos de redução de custos na manufatura de roupas; (3) a cadeia sucessiva de subcontratações entre grifes - fornecedores - oficinas, que tem por objetivo 
afastar a responsabilidade da real beneficiária do trabalho análogo ao escravo na linha de produção e, consequentemente, permite que os trabalhadores fiquem à mercê da fragilidade econômica das oficinas para obter o crédito dos direitos trabalhistas devidos; e (4) a massa de consumidores que compra produtos do mercado fast fashion sem se preocupar de ver além da proposta de mercado que cria moda diversificada a preço acessível, concentrando-se somente no que lhe traz satisfação imediata, o produto final.

Tal cenário pode e deve ser revertido a partir de uma ação integrada entre as autoridades públicas e a sociedade civil. Para isso, é preciso que seja conferido um maior enfoque às necessidades do trabalhador imigrante em situação irregular no país antes, durante e após o resgate; que se busque pelo reconhecimento da responsabilidade das magazines pelo trabalho escravo perpetrado ao longo de sua teia produtiva; além de ser elementar que o consumidor passe a assumir uma postura mais (re)ativa dentro da lógica de mercado em que está inserido, de modo a pressionar as marcas a estabelecerem um padrão de sustentabilidade em sua produção.

Por conseguinte, é imperioso, inicialmente, que sejam criadas políticas públicas que fulminem o trabalho escravo na raiz de seu problema, fixando os trabalhadores em sua cidade natal por meio de instrumentos que promovam uma vida digna ao trabalhador, além de se consolidar meios de enfrentamento direto ao tráfico de seres humanos, coibindo de forma precisa a ação dos aliciadores de mão de obra a partir de operações coordenadas entre grupos de fiscalização, MPT, ONGs, sindicatos, sociedade civil e autoridades da polícia rodoviária.

Também, é imprescindível que ocorram frequentes campanhas em prol do esclarecimento de trabalhadores imigrantes - que já se encontram prestando serviços em local estrangeiro - quanto aos seus direitos trabalhistas, oportunizando-se a regularização imediata de sua condição 
ilegal e, havendo o resgate, que seja proporcionado a estes trabalhadores a reinclusão no mercado de trabalho, a partir da promoção de ações que visem à educação básica e profisssional, assistência médica, auxílio moradia, etc., posto que a verdadeira libertação advém do acesso deste trabalhador a direitos que lhe permitam exercer sua cidadania.

De forma conjunta, é vital que se busque a responsabilização das grandes varejistas que sustentam a lógica do trabalho escravo contemporâneo, sendo certo que o reconhecimento destas como reais empregadoras ou ao menos como responsáveis solidárias do dano perpetrado contra a dignidade dos que laboram em sua cadeia - e da coletividade como um todo - consiste em forte instrumento para desmotivar a perpetuação desta prática, seja pelas altas multas estabelecidas, seja pela condenação criminal, seja pela imagem negativa agregada à marca que foi condenada pela prática de trabalho escravo.

E, finalmente, chegamos aos consumidores, os quais são capazes de ditar as regras que regulam o setor têxtil.

Repensar hábitos de consumo, buscar informação sobre as práticas da marca que - de certa forma - patrocina, priorizar a produção sustentável, pressionar as grandes grifes a mudarem sua postura a partir de boicotes, são algumas das muitas ferramentas que o consumidor pode utilizar para garantir um mercado mais humanizado.

Por todo o exposto, sustentamos que a realidade da Indústria da Moda precisa ser verdadeiramente enxergada e cada vez mais debatida pela sociedade, longe da cegueira deliberada da indiferença, sendo necessário que sejamos, sobretudo, voz daqueles a quem se nega humanidade, empenhando nossos melhores esforços na promoção de instrumentos de erradicação do trabalho análogo ao escravo que ajudem a construir uma nação efetivamente fundada na valorização do trabalho e na livre iniciativa, em que o lucro não se sobreponha jamais à dignidade do ser humano. 


\section{REFERÊNCIAS BIBLIOGRÁFICAS}

ABIT TÊXTIL E CONFECÇÃO. Perfil do Setor. Disponível em: $<$ http://www.abit.org.br/cont/perfil-do-setor>. Acesso em 15 ago. 2017.

AGÊNCIA BRASIL. Zara é autuada por não cumprir acordo para acabar com trabalho escravo. In: Carta Capital. 13/05/2015. Disponível em: $<$ https://www.cartacapital.com.br/economia/zara-e-autuada-por-naocumprir-acordo-para-acabar-com-trabalho-escravo-8409.html>. Acesso em 06 out. 2017.

ANDRADE, Carlos Eduardo Almeida Martins de. Do crime de redução à condição análoga à de escravo na legislação, doutrina e jurisprudência. In: Âmbito Jurídico, Rio Grande, XV, n. 98, mar 2012. Disponível em: $<$ http://www.ambitojuridico.com.br/site/?n_link=revista_artigos_leitura\&ar tigo_id $=11183 \&$ revista_caderno $=3>$. Acesso em 20 set. 2017.

APOLINÁRIO, V. Análise do Toyotismo e dos seus Princípios Racionalizantes aplicados à gestão da produção e do trabalho. Interface Revista do Centro de Ciências Sociais Aplicadas, v. 13, n. 2, p. 5-19, 2016.

ARANHA, Ana. "A dona ficava com o nosso salário". In: Repórter Brasil. 09/05/2015.

Disponível

em:

$<$ http://reporterbrasil.org.br/2015/05/a_dona_ficava_com_nosso_salario/>. Acesso em 06 out. 2017.

BIGNAMI, Renato. Trabalho escravo contemporâneo: O sweating system no contexto brasileiro como expressão do trabalho forçado urbano. Disponível em: $<$ https://www.sinait.org.br/arquivos/artigos/artigo19216c4627d24e2563a43 35ceb2c9469.pdf>. Acesso em 02 ago 2017.

BRASIL. Decreto-lei n. ${ }^{\circ}$ 5.452, de $1^{\circ}$ de maio de 1943 . Consolidação das Leis do Trabalho (1943). Atualizado pela Lei no 13.467, de 13 de julho de 2017.

BRASIL. Decreto-lei no 2.848, de 7 de dezembro de 1940. Código Penal (1940).

BRASIL. Estado de São Paulo. Lei no 14.946, de 28 de janeiro de 2013. Dispõe sobre a cassação da inscrição no cadastro de contribuintes do Imposto sobre Operações Relativas à Circulação de Mercadorias e sobre Prestações de Serviços de Transporte Interestadual e Intermunicipal e de 
Comunicação - ICMS, de qualquer empresa que faça uso direto ou indireto de trabalho escravo ou em condições análogas.

BRASIL. Lei n 10.406, de 10 de janeiro de 2002. Código Civil (2002).

BRASIL. Lei $n^{\circ} 10.608$, de 20 de dezembro de 2002. Altera a Lei no 7.998, de 11 de janeiro de 1990, para assegurar o pagamento de segurodesemprego ao trabalhador resgatado da condição análoga à de escravo.

BRASIL. Lei $\mathrm{n}^{\circ} 10.803$, de 11 de dezembro de 2003. Altera o art. 149 do Decreto-Lei no 2.848, de 7 de dezembro de 1940 - Código Penal, para estabelecer penas ao crime nele tipificado e indicar as hipóteses em que se configura condição análoga à de escravo.

BRASIL. Lei $\mathrm{n}^{\circ}$ 6.404, de 15 de dezembro de 1976. Lei das Sociedades Anônimas (1976).

BRASIL. Lei nº 13.445, de 24 de maio de 2017. Lei da Migração (2017).

BRASIL. Lei $n^{\circ}$ 6.938, de 31 de agosto de 1981. Política Nacional do Meio Ambiente (1981).

BRASIL. Lei no 8.078, de 11 de setembro de 1990. Código de Defesa do Consumidor (1990).

BRASIL. Ministério Público do Trabalho. Procuradoria Regional do Trabalho da $2^{a}$ Região. Ação Civil Pública. Réu: M5 Indústria e Comércio Ltda. 2014. Disponível em: <http://reporterbrasil.org.br/documentos/acpmofficer.pdf $>$. Acesso em 14 jul. 2017.

BRASIL. Norma Regulamentadora Nº 01 - Disposições Gerais (1978).

BRASIL. NR 10 - Segurança em instalações e serviços em eletricidade (1978).

BRASIL. NR 16 - Atividades e operações perigosas (1978).

BRASIL. NR 17 - Ergonomia (1978).

BRASIL. NR 23 - Proteção Contra Incêndios (1978).

BRASIL. NR 24 - Condições Sanitárias e de Conforto nos Locais de Trabalho (1978).

BRASIL. NR 31 - Segurança e saúde no trabalho na agricultura, pecuária silvicultura, exploração florestal e aquicultura (2005).

BRASIL. NR 5 - Comissão Interna de Prevenção de Acidentes (1978). 
BRASIL. NR 6 - Equipamento de Proteção Individual - EPI (1978).

BRASIL. NR-12 - Segurança no trabalho em máquinas e equipamentos (1978).

BRASIL. Portaria Interministerial MTPS/MMIRDH $n^{\circ} 4$ de 11/05/2016. Dispõe sobre as regras relativas ao Cadastro de Empregadores que tenham submetido trabalhadores a condições análogas à de escravo.

BRASIL. Portaria MTB 1.129/2017. Dispõe sobre os conceitos de trabalho forçado, jornada exaustiva e condições análogas à de escravo para fins de concessão de seguro-desemprego ao trabalhador que vier a ser resgatado em fiscalização do Ministério do Trabalho, nos termos do artigo 2-C da Lei $\mathrm{n}^{\circ}$ 7998, de 11 de janeiro de 1990; bem como altera dispositivos da PI MTPS/MMIRDH n ${ }^{\circ}$ 4, de 11 de maio de 2016.

BRASIL. Termo de Ajuste de Conduta $\mathrm{n}^{\circ}$ 21/2017 (Inquérito Civil $\mathrm{n}$. 0000393.2011.02.002/2). Disponível em: $<$ http://docplayer.com.br/54164020-Ic-de-autos-n-2-termo-de-ajuste-deconduta-n-d-1-2017.html>. Acesso em 10 out. 2017.

BRASIL. Termo de Ajuste de Conduta. (Inquérito Civil n. 0000393.2011.02.002/2). Disponível em: $<$ http://www.prt2.mpt.mp.br/servicos/termos-de-ajuste-deconduta?task=baixa\&format=raw\&arq=ni_8fI9oenKbxgoYerWk9G4wOwcQSkOKDDc50_A5LnHKjjw5580YGGKFeacs-ayJWKwwshHY3QS4q1X7Y Xw >. Acesso em: 06 out. 2017.

BRIANEZI, Thaís. Para procuradores, terceirização não anula culpa por trabalho escravo. In: Repórter Brasil. 14/11/2014. Disponível em $<$ http://reporterbrasil.org.br/2014/11/procuradores-defendemresponsabilizacao-civil-trabalhista-e-criminal-dos-elos-finais-das-cadeiasprodutivas-flagradas-com-trabalho-escravo/>. Acesso em 23 set. 2017.

BRITO FILHO, José Cláudio Monteiro de. Trabalho Decente: Análise jurídica da exploração do trabalho - Trabalho escravo e outras formas de trabalho indigno. $4^{\mathrm{a}}$ ed. São Paulo: LTr, 2016.

CABRAL, Bruno Fontenele. Breves comentários sobre a teoria da cegueira deliberada (willful blindness doctrine). In: Revista Jus Navigandi, ISSN 1518-4862, Teresina, ano 17, n. 3193, 29/03/2012. Disponível em: $<$ https:/jus.com.br/artigos/21395>. Acesso em: 24 set. 2017. 
CABREIRA, Lucas Ferreira; WOLFF, Simone. Precarização e informalidade na indústria de confecções em Cianorte: Crise na tutela trabalhista. Disponível em: $<$ http://www.estudosdotrabalho.org/texto/gt7/precarizacao.pdf $>$. Acesso em 17 set. 2017.

CACCIAMALI, Maria Cristina; AZEVEDO, Flávio Antônio de. Entre o tráfico humano e a opção da mobilidade social: A situação dos imigrantes bolivianos na cidade de São Paulo. In: Seminário Internacional Trabalho Escravo por Dívida e Direitos Humanos. Painel: A produção Científica em Construção - Estudos sobre Conflitos no Campo e Trabalho Escravo. 10/11/2005. Disponível em: < http://www.gptec.cfch.ufrj.br/pdfs/trafhumano.pdf $>$. Acesso em 02 nov. 2017.

CAMPOS, André (Repórter Brasil); HUIJSTEE, Mariëtte van; THEUWS, Martje (SOMO). Da responsabilidade moral à responsabilização jurídica? As condições de escravidão moderna na cadeia global de suprimentos da indústria do vestuário e a necessidade de fortalecer os marcos regulatórios: o caso da Inditex-Zara no Brasil. Amsterdã, mai. 2015. Disponível em $<$ http://reporterbrasil.org.br/wp-content/uploads/2015/05/Reporter-Brasilweb-P.pdf>. Acesso em 20 set. 2017.

CAMPOS, André. Zara corta oficinas de imigrantes e será multada por discriminação. In: Repórter Brasil. 09/05/2015. Disponível em: $<$ http://reporterbrasil.org.br/2015/05/zara-corta-oficinas-de-imigrantes-esera-multada-por-discriminacao/>. Acesso em 05 out. 2017.

CARNEIRO, Paloma Torres. Função social da empresa. In: Âmbito Jurídico, Rio Grande, XIV, n. 92, set 2011. Disponível em: $<$ http://www.ambitojuridico.com.br/site/index.php?n_link=revista_artigos_leitura\&artigo_id $=1$ 0318>. Acesso em: 17 ago. 2015.

CASADO, Letícia. Ministra do STF concede liminar que suspende portaria do trabalho escravo. In: Folha de São Paulo. 24/10/2017. Disponível em: $<$ http://www1.folha.uol.com.br/mercado/2017/10/1929697-ministra-do-stfconcede-liminar-que-suspende-portaria-do-trabalho-escravo.shtml $>$. Acesso em 26 out. 2017.

CAVALCANTI, Tiago Muniz. Trabalho escravo na moda: os grilhões ocultos da elite brasileira. In: Repórter Brasil. 26/11/2013. Disponível em: $<$ http://reporterbrasil.org.br/2013/11/os-grilhoes-ocultos-da-elitebrasileira/>. Acesso em 02 out. 2017. 
CHAVES, Maria Cláudia Gomes. Dumping social como fator de precarização das relações de trabalho. In: Conteudo Juridico, Brasilia-DF: $16 / 04 / 2010$

Disponivel

em:

$<$ http://www.conteudojuridico.com.br/?artigos\&ver=2.26586>. Acesso em: 24 ago. 2017.

COSTA, Flávio Dino de Castro e. O Combate ao Trabalho Forçado no Brasil: Aspectos Jurídicos. Revista do Ministério Público do Trabalho, Brasília, ano XIII, $n^{\circ}$. 26. São Paulo: Ltr, 2003. p. 86-109. Disponível em: $<$ http://www.anpt.org.br/attachments/article/2720/Revista\%20MPT\%20\%20Edi\%C3\%A7\%C3\%A3o\%2026.pdf>. Acesso em 04 fev. 2017. DELGADO. Maurício Godinho. Curso de Direito do Trabalho. 15a ed. São Paulo: LTr, 2016.

FILGUEIRAS, Vitor Araújo. Trabalho análogo ao escravo e o limite da relação de emprego: Natureza e disputa na regulação do Estado. In: PRADO, Adonia Antunes; GALVÃO, Edna Maria; FIGUEIRA, Ricardo Rezende (Orgs). A Universidade Discute a Escravidão Contemporânea: Práticas e Reflexões. $1^{\mathrm{a}}$ ed. Rio de Janeiro: Mauad X, 2015. p. 133-156.

FRAGA, Cristiano. Subordinação Estrutural: Um novo paradigma para as relações de emprego. Disponível em: $<$ http://www3.pucrs.br/pucrs/files/uni/poa/direito/graduacao/tcc/tcc2/trabal hos2011_1/cristiano_fraga.pdf $>$. Acesso em 20 ago. 2017.

G1. Justiça de SP mantém ação contra Zara por trabalho escravo. 15/04/2014. Disponível em: <http://g1.globo.com/saopaulo/noticia/2014/04/justica-de-sp-mantem-acao-contra-zara-por-trabalhoescravo.html>. Acesso em 06 out. 2017.

GUADAGNUCCI, Natália. Zara lança primeira coleção sustentável no Brasil. In: L'OFFICIEL. 10/03/2017. Disponível em: < https://www.revistalofficiel.com.br/mode/zara-lanca-primeira-colecaosustentavel-no-brasil>. Acesso em 02 nov. 2017.

HASHIZUME, Maurício. Escravidão é flagrada em oficina de costura ligada à Marisa. In: Repórter Brasil, 2010. Disponível em $<$ http://reporterbrasil.org.br/2010/03/escravidao-e-flagrada-em-oficina-decostura-ligada-a-marisa/>. Acesso em 19 out. 2017.

HASHIZUME, Maurício. Tragédia em Bangladesh simboliza despotismo do lucro. In: Repórter Brasil. 10/05/2013. Disponível em: $<$ http://reporterbrasil.org.br/2013/05/tragedia-em-bangladesh-simbolizadespotismo-do-lucro/>. Acesso em 11 Out. 2017. 
LIGA DAS NAÇÕES. Convenção das Nações Unidas sobre Escravatura. Assinada em Genebra, em 25 de setembro 1926, e emendada pelo protocolo aberto à assinatura ou à aceitação na sede da organização das Nações Unidas, Nova Iorque, em 7 de dezembro de 1953.

MANSOLDO, Felipe Fayer. Considerações sobre o Caso Zara do Brasil e a possível inadequação do compromisso de ajustamento de conduta como resposta eficaz às violações de direitos humanos. Disponível em: $<\mathrm{http}$ :/homacdhe.com/dialogossobredireitoshumanos/wpcontent/uploads/sites/5/2017/02/CASO-ZARA.pdf $>$. Acesso em 08 out. 2017.

MATSUMOTO, Jorge Gonzaga; DUARTE, Vinicius Franco. Regras da "lista suja" do trabalho escravo necessitam de uma faxina. In: Revista Consultor Jurídico. 27/01/2017. Disponível em: $<$ https://www.conjur.com.br/2017-jan-27/regras-lista-suja-trabalho-escravonecessitam-faxina>. Acesso em 05 out. 2017.

MELO, Luís Antônio Camargo de. Premissas para um eficaz combate ao trabalho escravo. Revista do Ministério Público do Trabalho, Brasília, ano XIII, $\mathrm{n}^{\circ}$. 26. São Paulo: Ltr, 2003. p. 11-33. Disponível em: $<$ http://www.anpt.org.br/attachments/article/2720/Revista\%20MPT\%20\%20Edi\%C3\%A7\%C3\%A3o\%2026.pdf>. Acesso em 04 fev. 2017.

MENDES, Almara Nogueira. Nova forma de escravidão urbana: Trabalho de imigrantes. Revista do Ministério Público do Trabalho, Brasília, ano XIII, n. 26. São Paulo: Ltr, 2003. p. 67-70. Disponível em: $<$ http://www.anpt.org.br/attachments/article/2720/Revista\%20MPT\%20\%20Edi\%C3\%A7\%C3\%A3o\%2026.pdf>. Acesso em 04 fev. 2017.

MERÇON, Marineis. Imigrantes bolivianos no trabalho escravo contemporâneo: análise do caso Zara a partir das RPGs. In: Revista do CEDS. Periódico do Centro de Estudos em Desenvolvimento Sustentável da UNDB. N. 2 - Vol. 1 - março/julho 2015 - Semestral. Disponível em: $<$ http://www.undb.edu.br/publicacoes/arquivos/revceds_n_2_imigrantes_bo livianos_e_trabalho_escravo_contemporaneo_caso_zara_marineis_mercon. pdf $>$. Acesso em 23 out. 2017.

MINISTÉRIO DOS DIREITOS HUMANOS. Combate ao Trabalho Escravo. Disponível:

$<$ http://www.sdh.gov.br/assuntos/conatrae/programas/comissao-nacionalpara-a-erradicacao-do-trabalho-escravo>. Acesso em 13 out. 2017. 
MPT 24a REGIÃO. MPT lembra 20 anos do grupo móvel de combate ao trabalho escravo. Disponível em: <http://www.prt24.mpt.mp.br/informese/noticias-do-mpt-ms/345-mpt-lembra-20-anos-do-grupo-movel-decombate-ao-trabalho-escravo $>$. Acesso em 12 out. 2017.

MPT. Observatório Digital do Trabalho Escravo no Brasil. Disponível em: $<$ https://observatorioescravo.mpt.mp.br/>. Acesso em 06 ago. 2017.

NAGAHIRO, Vanessa Cristina Parra; MELLER, Fernanda. Responsabilização das empresas nas cadeias produtivas frente ao trabalho escravo contemporâneo. In: Âmbito Jurídico, Rio Grande, XIX, n. 144, jan 2016. Disponível em: <http://www.ambitojuridico.com.br/site/?n_link=revista_artigos_leitura\&artigo_id=16700>. Acesso em 12 out 2017.

O GLOBO. Ranking lista as marcas de vestuário mais valiosas do mundo em 2017. 13/03/2017. Disponível em: $<$ https://oglobo.globo.com/ela/moda/ranking-lista-as-marcas-de-vestuariomais-valiosas-do-mundo-em-2017-21051051>. Acesso em 05 out. 2017.

OIT. Convenção ${ }^{\circ}$ 100. Igualdade de Remuneração de Homens e Mulheres Trabalhadores por Trabalho de Igual Valor. Aprovada na $34^{\mathrm{a}}$ reunião da Conferência Internacional do Trabalho (Genebra - 1951), entrou em vigor no plano internacional em 23/05/1953. Ratificada em 25/04/1957 pelo Brasil. Promulgada pelo Decreto n. 41.721, de 25/06/1957.

OIT. Convenção ${ }^{\circ}$ 105. Abolição do Trabalho Forçado. Aprovada na $40^{\mathrm{a}}$ reunião da Conferência Internacional do Trabalho (Genebra - 1957), entrou em vigor no plano internacional em 17/01/1959. Ratificada em 18/06/1965 pelo Brasil. Promulgada pelo Decreto $\mathrm{n}^{\circ}$ 58.822, de 14/07/1966.

OIT. Convenção $\mathrm{n}^{\circ}$ 111. Discriminação em Matéria de Emprego e Ocupação. Aprovada na $42^{\mathrm{a}}$ reunião da Conferência Internacional do Trabalho (Genebra - 1958), entrou em vigor no plano internacional em 15/06/1960. Ratificada em 26/11/1965 pelo Brasil. Promulgada pelo Decreto n. 62.150, de 19/01/1968.

OIT. Convenção $\mathrm{n}^{\circ}$ 138. Aprovada na $58^{\mathrm{a}}$ reunião da Conferência Internacional do Trabalho (Genebra - 1973), entrou em vigor no plano internacional em 19/06/1976. Idade Mínima para Admissão. Ratificada em 28/06/2001 pelo Brasil. Promulgada pelo Decreto n. 4.134, de 15/02/2002. 
OIT. Convenção ${ }^{\circ}$ 142. Orientação Profissional e a Formação Profissional no Desenvolvimento de Recursos Humanos. Aprovada na $60^{\mathrm{a}}$ reunião da Conferência Internacional do Trabalho (Genebra - 1975), entrou em vigor no plano internacional em 19/07/1977. Ratificada em 24/11/1981 pelo Brasil. Promulgada pelo Decreto n. 98.656, de 21/12/1989.

OIT. Convenção $\mathrm{n}^{\circ} 29$. Trabalho Forçado ou Obrigatório. Aprovada na $14^{\mathrm{a}}$ reunião da Conferência Internacional do Trabalho (Genebra - 1930), entrou em vigor no plano internacional em 01/05/32. Ratificada em 25/04/1957 pelo Brasil. Promulgada pelo Decreto $\mathrm{n}^{\circ}$ 41.721, de 25/06/1957.

OIT. Convenção $\mathrm{n}^{\circ}$ 87. Liberdade Sindical e Proteção ao Direito de Sindicalização. A Conferência Geral da Organização Internacional do Trabalho. Convocada em São Francisco pelo Conselho de Administração da Repartição Internacional do Trabalho e ali reunida a 17 de junho de 1948, em sua $31^{\text {a }}$ Sessão. Não ratificada.

OIT. Convenção $n^{\circ}$ 98. Direito de Sindicalização e de Negociação Coletiva. Aprovada na $32^{\mathrm{a}}$ reunião da Conferência Internacional do Trabalho (Genebra - 1949), entrou em vigor no plano internacional em 18/07/1951. Ratificada em 18/11/1952 pelo Brasil. Promulgada pelo Decreto n. 33.196, de 29/06/53.

OIT. O trabalho forçado no Brasil. Disponível em: $<$ http://www.ilo.org/brasilia/temas/trabalho-escravo/WCMS_393066/lang-pt/index.htm>. Acesso em 02 set. 2017.

OJEDA, Igor. Alckmin sanciona lei que fecha empresa que usar trabalho escravo em São Paulo. In: Repórter Brasil. 23/01/2013. Disponível em: $<$ http://reporterbrasil.org.br/2013/01/alckmin-sanciona-lei-que-fechaempresa-que-usa-trabalho-escravo/>. Acesso em 24 out. 2017.

OJEDA, Igor. Fiscalização flagra exploração de trabalho escravo na confecção de roupas da Renner. In: Repórter Brasil. 2014. Disponível em: $<$ http://reporterbrasil.org.br/2014/11/fiscalizacao-flagra-exploracao-detrabalho-escravo-na-confeccao-de-roupas-da-renner/>. Acesso em 20 out. 2017.

OMS, Carolina; QUEIROZ, Nana. Moda a qualquer custo. In: Revista AZMina. 28/08/2015 9/03/1988. Disponível em $<$ http://azmina.com.br/2015/08/moda-a-qualquer-custo/>. Acesso em 02 jul. 2017. 
ONU. Convenção Suplementar relativa à abolição da escravatura, do tráfico de escravos e das instituições e práticas análogas à escravatura. Adotada em Genebra, a 7 de setembro de 1956. Entrada em vigor, para o Brasil, a 6 de janeiro de 1966. Promulgada pelo Decreto Presidencial $n^{\circ} 58.563$ de $1^{\circ}$ de junho de 1966.

ONU. Declaração Universal dos Direitos Humanos. Adotada e proclamada pela Assembléia Geral das Nações Unidas (resolução 217 A III) em 10 de dezembro 1948.

ONU. Pacto Internacional sobre os Direitos Econômicos, Sociais e Culturais. Adotado e aberto à assinatura, ratificação e adesão pela resolução 2200A (XXI) da Assembléia Geral das Nações Unidas, de 16 de Dezembro de 1966. Entrada em vigor na ordem internacional: 3 de Janeiro de 1976, em conformidade com o artigo $27 .^{\circ}$.

ONU. Protocolo de Palermo. Protocolo Adicional à Convenção das Nações Unidas contra a Criminalidade Organizada Transnacional relativo à Prevenção, à Repressão e à Punição do Tráfico de Pessoas, em especial de Mulheres e Crianças (2003).. Promulgado pelo Decreto $\mathrm{n}^{0}$ 5.017, de $12 / 03 / 2004$.

ONUBR. Trabalho Escravo. Brasília, abril de 2016. Disponível em: $<$ https://nacoesunidas.org/wp-content/uploads/2016/04/position-papertrabalho-escravo.pdf $>$. Acesso em 16 set. 2017.

PRESSE, Francine. OIT expressa preocupação por decreto sobre trabalho escravo no Brasil. In: G1. 16/10/2017. Disponível em: $<$ https://www.google.com.br/url?sa $=\mathrm{t} \& \mathrm{rct}=\mathrm{j} \& \mathrm{q}=\& \mathrm{esrc}=\mathrm{s} \&$ source $=$ web\&cd $=1 \& \mathrm{cad}=$ rja\&uact $=8 \& \mathrm{ved}=0$ ahUKEwj376-BjWAhXBUZAKHZ_gC_UQqOcBCCYwAA\&url=https\%3A\%2F\%2Fg1. globo.com $\% 2$ Feconomia $\% 2$ Fnoticia $\% 2$ Foit-expressa-preocupacao-pordecreto-sobre-trabalho-escravo-nobrasil.ghtml\&usg=AOvVaw2MlqOHPVBM2r-BtK5WWjZl>. Acesso em 21 out. 2017.

PYL, Bianca; HASHIZUME, Maurício. Roupas da Zara são fabricadas com mão de obra escrava. In: Repórter Brasil. 16/08/2011. Disponível em: $<$ http://reporterbrasil.org.br/2011/08/roupas-da-zara-sao-fabricadas-commao-de-obra-escrava/>. Acesso em 05 out. 2017.

RBA. Temer faz agrado a bancada ruralista e altera conceitos de 'trabalho escravo'. In: Rede Brasil Atual. 16/10/2017. Disponível em: $<$ http://www.redebrasilatual.com.br/cidadania/2017/10/temer-faz-agrado-a- 
bancada-ruralista-e-altera-conceitos-de-trabalho-escravo>. Acesso em 21 out. 2017.

REPÓRTER BRASIL. Íntegra da sentença judicial em que Zara é responsabilizada por escravidão. 14/04/2014. Disponível em: $<$ http://reporterbrasil.org.br/2014/04/integra-da-sentenca-judicial-em-quezara-e-responsabilizada-por-escravidao/>. Acesso em 06 out.2017.

REPÓRTER BRASIL. Migração: O Brasil em Movimento / Natália Suzuki (org.); Equipe 'Escravo, nem pensar'. - São Paulo, 2017. Disponível em: $<$ http://escravonempensar.org.br/wp-content/uploads/2017/10/cadernomigrac\%CC\%A7a\%CC\%83o-22_08_17-baixa.pdf $>$. Acesso em 02 set. 2017.

REVISTA CONSULTOR JURÍDICO. Empresa deve ficar dois anos na "lista suja" mesmo se regularizada, diz TST. 21/09/2017. Disponível em: $<$ https://www.conjur.com.br/2017-set-21/empresa-ficar-dois-anos-listasuja-mesmo-regularizada>. Acesso em 04 out. 2017.

RIVAS, Katherine. Cicatrizes da tragédia em oficinas têxteis de Bangladesh. In: Carta Capital. 23/05/2013. Disponível em: $<$ http://envolverde.cartacapital.com.br/cicatrizes-da-tragedia-em-oficinastexteis-de-bangladesh/>. Acesso em 11 Out. 2017.

SAKAMOTO, Leonardo (Org.). Comitê de Coordenação e Monitoramento do Pacto Nacional pela Erradicação do Trabalho Escravo. Cartilha das Confecções. In: Repórter Brasil. 2012. Disponível em: $<$ http://reporterbrasil.org.br/documentos/pacto_web.pdf $>$. Acesso em 20 out. 2017.

SAKAMOTO, Leonardo. Justiça determina que governo volte a divulgar "lista suja" da escravidão. In: Repórter Brasil. 19/12/2016. Disponível em: $<$ http://reporterbrasil.org.br/2016/12/justica-determina-que-governo-voltea-divulgar-lista-suja-da-escravidao/>.Acesso em 04 out. 2017.

SANTINI, Daniel. Em São Paulo, CPI do Trabalho Escravo cria canal para receber denúncias. In: Repórter Brasil. 24/04/2014. Disponível em: $<$ http://reporterbrasil.org.br/2014/04/em-sao-paulo-cpi-do-trabalho-escravocria-canal-para-receber-denuncias/>. Acesso em 04 out. 2017.

SANTOS, Ronaldo Lima dos. A escravidão por dívidas nas relações de trabalho no Brasil contemporâneo. Revista do Ministério Público do Trabalho, Brasília, ano XIII, n . 26. São Paulo: Ltr, 2003. p. 47-66. Disponível

em: 
$<$ http://www.anpt.org.br/attachments/article/2720/Revista\%20MPT\%20\%20Edi\%C3\%A7\%C3\%A3o\%2026.pdf>. Acesso em 04 fev. 2017.

SEGATTI, Ana Elisa Alves Brito; NOVAES, Dirce Trevisi Prado; NOGUEIRA, Christiane Vieira; SABINO, João Filipe Moreira Lacerda; FORTES, Mariana Flesch. Trabalho Escravo: Reflexões sobre a Responsabilidade na Cadeia Produtiva. Revista do Ministério Público do Trabalho, Brasília, ano XXIV, n . 48. São Paulo: Ltr, 2015. p. 68. Disponível em: $<$ http://www.tridiacriacao.com/clientes/anpt/images/olds/arquivos/revistaMPT-48_anpt23121.pdf >. Acesso em 04 out.. 2017.

SOARES, Evanna. Meios coadjuvantes de combate ao trabalho escravo pelo Ministério Público do Trabalho. Revista do Ministério Público do Trabalho, Brasília, ano XIII, nº 26. São Paulo: Ltr, 2003. p. 34-46. Disponível em: $<$ http://www.anpt.org.br/attachments/article/2720/Revista\%20MPT\%20\%20Edi\%C3\%A7\%C3\%A3o\%2026.pdf>. Acesso em 04 fev. 2017.

TIMÓTEO, Gabrielle Loiuse Soares. Trabalho em condições análogas à escravidão na sociedade de consumo. In: PRADO, Adonia Antunes; GALVÃO, Edna Maria; FIGUEIRA, Ricardo Rezende (Orgs). A Universidade Discute a Escravidão Contemporânea: Práticas e Reflexões. $1^{\mathrm{a}}$ ed. Rio de Janeiro: Mauad X, 2015. p. 239-251.

Tribunal Superior do Trabalho. Rede de lojas é condenada em dano moral coletivo por exigir jornada excessiva. 2014. Disponível em $<$ http://www.tst.jus.br/noticias//asset_publisher/89Dk/content/id/9153643>. Acesso em 20 out. 2017.

VELASCO, Clara; MANTOVANI, Flávia. Em 10 anos, número de imigrantes aumenta 160\% no Brasil, diz PF. In: G1. 25/06/2016. Disponível em: $\quad<$ http://g1.globo.com/mundo/noticia/2016/06/em-10-anos-numero-deimigrantes-aumenta-160-no-brasil-diz-pf.html>. Acesso em 16 out. 2017.

VILLELA, Flávia. Corte Interamericana de Direitos Humanos condena Brasil por trabalho escravo. In: Agência Brasil. 16/12/2016. Disponível em: $<$ http://agenciabrasil.ebc.com.br/direitos-humanos/noticia/2016-12/corteinteramericana-de-direitos-humanos-condena-brasil-por $>$. Acesso em 26 out. 2017. 